\title{
HISTORIAS DE FAMILIA ETNOGRAFÍA DELIRANTE SOBRE EL AMOR, LA VIOLENCIA Y LAS DROGAS
}

\section{CÉSAR AUGUSTO TAPIAS HERNÁNDEZ}

Prólogo de Joanne Rappaport
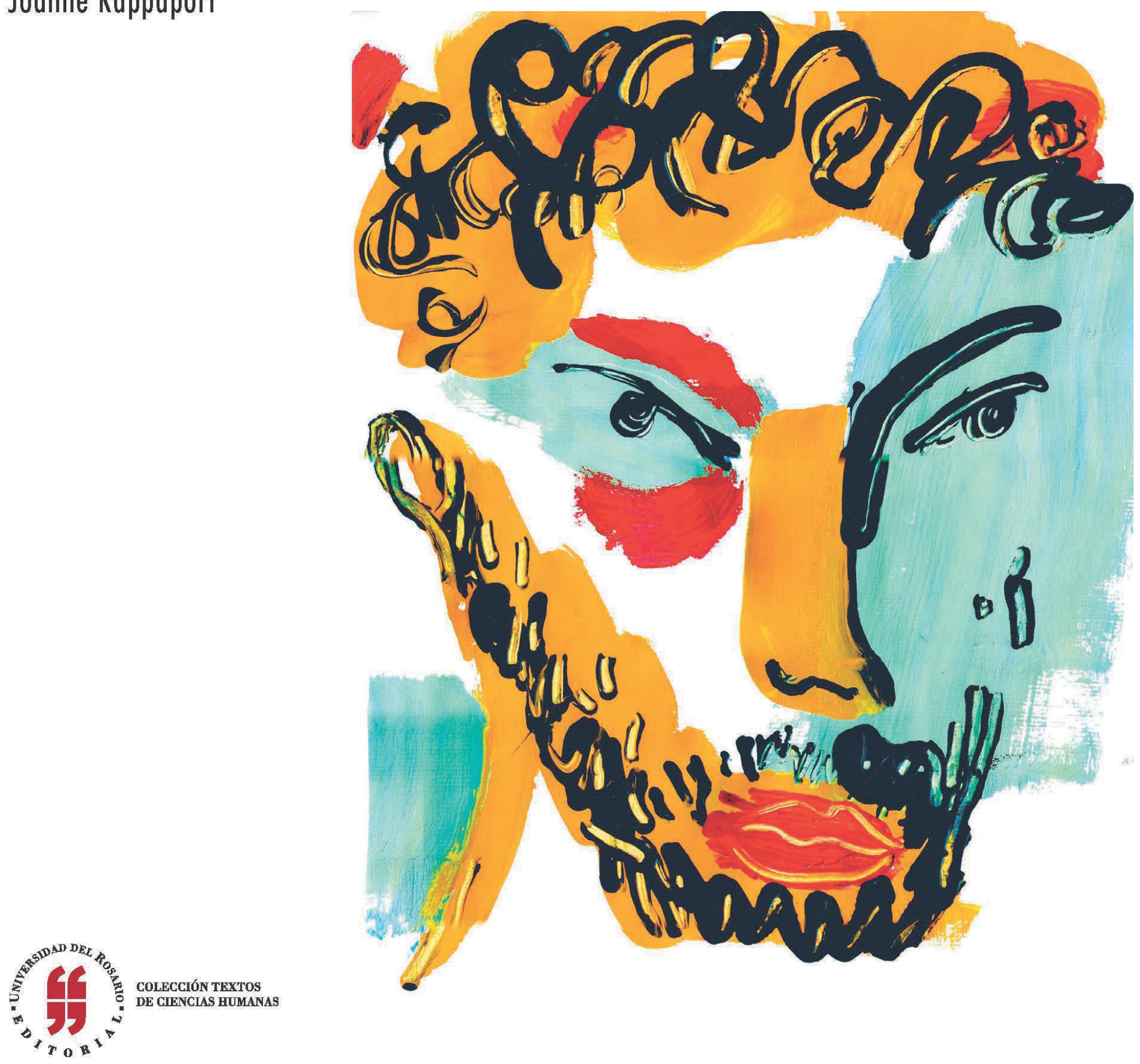

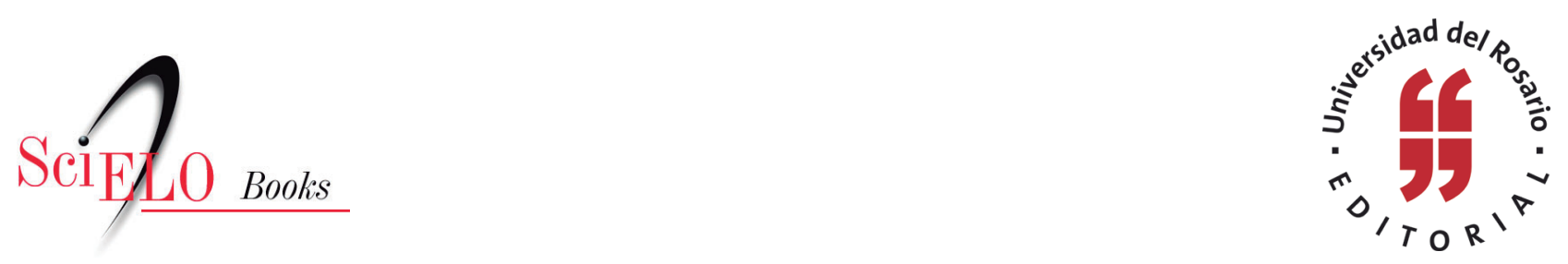

\title{
Historias de família \\ Etnografía delirante sobre el amor, la violencia y las drogas
}

\author{
César Augusto Tapias Hernández
}

\section{SciELO Books / SciELO Livros / SciELO Libros}

TAPIAS HERNÁNDEZ, C.A. Historias de familia: Etnografía delirante sobre el amor, la violencia y las drogas [online]. Bogotá: Editorial Universidad del Rosario, 2014, 161 p. Textos de ciencias humanas collection. ISBN: 978-958-738-543-4. https://doi.org/10.7476/9789587385434.

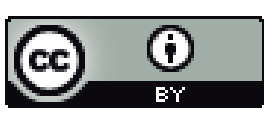

All the contents of this work, except where otherwise noted, is licensed under a Creative Commons Attribution 4.0 $\underline{\text { International license. }}$

Todo o conteúdo deste trabalho, exceto quando houver ressalva, é publicado sob a licença Creative Commons Atribição $\underline{4.0}$.

Todo el contenido de esta obra, excepto donde se indique lo contrario, está bajo licencia de la licencia Creative Commons Reconocimento 4.0. 


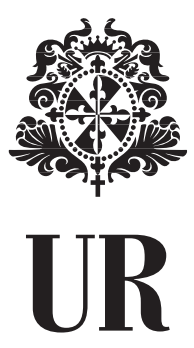





\section{Historias de familia \\ Etnografía delirante sobre el amor, \\ la violencia y las drogas}


Tapias Hernández, César Augusto

Historias de familia: Etnografía delirante sobre el amor, la violencia y las drogas / César Augusto Tapias Hernández. - Bogotá: Editorial Universidad del Rosario, Escuela de Ciencias Humanas, 2014.

xi, 161 páginas. - (Colección Textos de Ciencias Humanas).

Incluye referencias bibliográficas.

ISBN: 978-958-738-542-7 (rústica)

ISBN: 978-958-738-543-4 (digital)

Etnografía / Familia / Violencia / Violencia conyugal / Narcotráfico / Sociología / I. Título / II. Serie.

306.8

SCDD 20

Catalogación en la fuente - Universidad del Rosario. Biblioteca

amv

Octubre 02 de 2014

Hecho el depósito legal que marca el Decreto 460 de 1995 


\section{Historias de familia Etnografía delirante sobre el amor, la violencia y las drogas}

César Augusto Tapias Hernández 


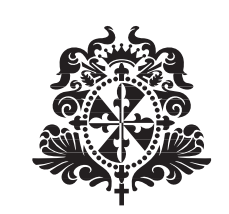

Colección Textos de Ciencias Humanas

(C) 2014 Editorial Universidad del Rosario

(C) 2014 Universidad del Rosario, Escuela de Ciencias Humanas

(c) 2014 César Augusto Tapias Hernández

C 2014 Joanne Rappaport, por el Prólogo

Editorial Universidad del Rosario

Carrera 7 No. 12B-41, of. 501 • Tel: 2970200 Ext. 7724

http://editorial.urosario.edu.co
Primera edición: Bogotá, D.C., noviembre de 2014

ISBN: 978-958-738-542-7 (rústica) ISBN: 978-958-738-543-4 (digital)

Coordinación editorial: Editorial Universidad del Rosario Corrección de estilo: Ella Suárez

Diagramación: Martha Echeverry

Diseño de cubierta: Miguel Ramírez, Kilka D. G.

Impresión: Estrategikmente Ltda.

Impreso y hecho en Colombia

Printed and made in Colombia

LIBRO RESULTADO DE INVESTIGACIÓN

Fecha de evaluación: 27 de septiembre de 2013

Fecha de aceptación: 25 de julio de 2014

Todos los derechos reservados. Esta obra no puede ser reproducida sin el permiso previo escrito de la Editorial Universidad del Rosario 
Porque la otra cara de ese amor es la violencia, el atropello, el chantaje, la manipulación.

Alonso Buitrago

Estamos ligados a nuestra familia porque nos sentimos ligados a la persona de nuestro padre, de nuestra madre, de nuestra mujer, de nuestros hijos. Era muy diferente un tiempo atrás, cuando - al contrario - los vínculos que se derivaban de las cosas prevalecian sobre lo procedente de las personas, cuando la organización familiar tenía como primer objetivo conservar en la familia los bienes domésticos y cuando todas las consideraciones personales eran secundarias. Durkheim, Fonctions sociales et institutions

Las familias conservan durante siglos enteros el mismo estado y a menudo el mismo lugar social. Tocqueville, La democracia en América

Desarrollar la llamada ambivalencia de las relaciones familiares en clave dialógica, es decir, entender la familia como pura comunidad de diálogo.

Habermas, Teoría de la acción comunicativa

La horda es el más elevado de los grupos sociales que hemos podido observar en los animales. Parece compuesto de familias, pero ya en su origen la familia y el rebaño son antagónicos; se desarrollan en razón inversa una y otro.

Espinas, Des societés animales. Stude de psychologie comparée

A familia não existe para satisfazer uma ou algumas funções sociais, mas um leque potencialmente indefinido, enquanto a familia é uma relação social plena, ou seja, um fenômeno social total [...] que implica todas as dimensóes da existencia humana.

Donati, Manual em a sociologia da familia 
En memoria de los abuelos... ... Para Jacobo

Pero esto no es una novela. ¿Cómo podría llamarlo?... En suma, solo son frases. No es preciso pulirlas. De momento solo estoy pensando en voz alta. No tengo aquí ningún deber moral. Yo... Pues sí, yo solo estoy pensando. Hace tiempo que no pensaba nada y quizás tarde mucho en volver a hacerlo. Pero ahora estoy pensando. Y seguiré haciéndolo hasta el amanecer.

Documento Uno de Sumire, en Sputnik, mi amor Haruki Murakami (1999). 


\section{Contenido}

Prólogo ....................................................................................................

Joanne Rappaport

1. De cómo un tío mío atracó a una tía mía............................................................ 5

2. De cuando Katherine vio a Dalí .........................................................................

3. La tía Emma, la hermana...........................................................................

4. ¡Que viva el presidente Tales!.......................................................................... 17

5. Yiyo: humo y brisa conjugada..................................................................... 21

6. Tensionarte-trazos de Wbeimar ....................................................................... 25

7. Yo no sé, hermano, es una orden................................................................... 29

8. La mamita Gélica.......................................................................................... 33

9. El segundo nombre de mi mamá es Inés........................................................

10. El tiempo / en el amor / y / sin él...................................................................... 41

11. La huelga del 69 (primera parte) …………………………………………...

12. La huelga del 69 (segunda parte) …………………………………………... 
13. Mi hermanito o la danza ebria........................................................................

14. ¡A a a a mí, me me me echaron de la casa! ......................................................

15. Eso para mí era como un sueño .......................................................................

16. Cuando uno se va a manejar mal, no hay quién lo ataje.................................. 67

17. Metáfora para las niñas..................................................................................

18. Edison de Jesús Fernández ...........................................................................

19. ¿Es la Biblia tan solo un buen libro?.............................................................. 81

20. Donde quiera que uno esté hay que trabajar.................................................. 85

21. Ellos tienen su inglés y lo entienden a uno .....................................................

22. De recuerdos, memorias y nostalgias .............................................................

23. Esfuerzo propio............................................................................................

24. Mujeres en exceso ……………………………………………………….. 101

25. Sus brazos gruesos desnudos sobre el muro .................................................... 109

26. ¡Esos ojos, muchachos! Esos ojos................................................................ 115

27. Una caricia que después no reclame amor...................................................... 119

28. De Jair y, de paso, de mi tío Ed ..................................................................... 123

29. De un primo llamado Óscar ......................................................................... 127

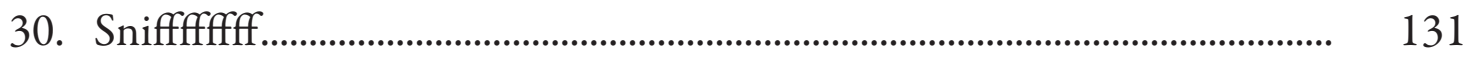

31. "Caregato, vaya y tráigame un armao" ............................................................ 135 
33. La Coca-Cola mata el alcohol.

34. A mi papá le tiemblan mucho las manos.

35. La mamita está borracha

Epílogo

153

Glosario

155

Bibliografía

157 



\section{Prólogo}

En esta colección de historias, César Augusto Tapias Hernández nos abre una ventana al mundo de su familia, un retrato vívido, polícromo, a veces violento y otras veces lleno de calor humano, que continuamente enlaza el pathos con el humor. Etnógrafo por excelencia, César intenta franquear la brecha inestable entre la etnografía y la ficción al compartir con sus lectores una serie de encuentros etnográficos elaborados en forma de cuentos, resaltando de esta manera no solo las condiciones en las cuales viven estas personas del sector popular antioqueño y sus narraciones, sino también sus sentimientos: tanto de los narradores como del etnógrafo, este último siendo más que un investigador. En este libro, César no toma la distancia generalmente asumida por los científicos sociales, sino que funciona como un preguntón cariñoso que está ubicado dentro del círculo familiar.

Esta es la segunda etapa de la invitación que nos hace César a compartir su familia con nosotros. Hace tres años publicó Fumando mañas, una exploración autoetnográfica de un expendio de drogas en Medellín, ubicado en la casa de sus primos. En ese libro, César experimenta con varias formas de exposición y nos ofrece fragmentos de observación etnográfica yuxtapuestos con dibujos hechos por sus familiares y diálogos con la Cucha, sus primos y primas, y otras personas allegadas a la casa - Leysy, Malena, El Mocho, La Chava, El Pili y otros-. Suplementa esta riqueza de miradas, que a veces son cristalinas y a veces ambiguas, con contextualizaciones históricas y sociológicas, cerrando el libro con un análisis muy astuto de la violencia de la vida cotidiana de esta familia paisa.

Historias de familia es diferente. Aquí, César permite que las descripciones etnográficas ficcionalizadas hablen por sí mismas. Si Fumando mañas es exitoso en su representación de las ambivalencias de la violencia cotidiana familiar, en Historias de familia nos acercamos aún más a sus parientes; los conocemos no solo como vendedores de drogas ilícitas o padres de familia fallidos (aunque presenta algunas instancias de violencia familiar, por ejemplo, el primer cuento en que su tía 
es atracada en la calle por uno de sus tíos), también nos los muestra como migrantes trasplantados de Titiribí a los barrios populares de Medellín y transeúntes monolingües en las periferias latinas de la metrópoli de Nueva York. Nos hace entrar en los momentos de indecisión y de conflicto familiar cuando sus personajes van a contraer matrimonio y nos muestra el temor que sienten ante la supuesta negativa del padre, pero en últimas revela que él es el que da la bienvenida a la pareja. Pinta un retrato de la lucha sindicalista a través de varias viñetas de una huelga vista por los ojos del tío Jaime, cuya narración se centra en el despido que recibió por boca del presidente de la República. Detalla el mal de asma que le cae a su abuela, la mamita Gélica, con la muerte de sus hijos, después de llevarlos al hospital bajo la lluvia. Nos presenta a "Yijo", hombre que nunca habla pero que es un mago con los naipes...

Y todo lo pinta vívidamente. Los Fernández y los Tales hablan como paisas, con una opulencia léxica que trasciende lo que encontré en Fumando mañas (yo como anglohablante con poca experiencia en Antioquia, a veces me desorientaba al negociar el matorral del lenguaje, lo que me esforzó a entrar más profundamente en el contexto etnográfico). Nos guía por los paisajes en que se mueven las familias. La construcción de una casa en el lote de El Pedregal, donde la tía Carmen tiene que subirse al bus con los zapatos en la mano por evitar el barrial. La casa, con sus habitaciones, sus dos patios, su cocina grande: nos lleva a conocerla de pieza en pieza. El negocio del tío Iván, en el terminal de buses, cuyas flotas despegan hacia lugares bélicos conocidos como "Bosnia" y "Jersegovina”, atendidos por ayudantes descalzos, sin camisas, quemados por el sol. Es un mundo lleno de movimiento, marcado por actividades que en otros contextos parecerían insignificantes - ponerse los zapatos después de subirse al autobús, los bailes de los alistadores de los buses - pero que aquí pintan un mundo palpable, lleno de ruidos y olores, saturado con la vida cotidiana.

La gente que se mueve en estos panoramas la conocemos a través de sus diálogos con el etnógrafo. Por ejemplo, la conversación que sostiene con su tío Gildardo. El tío se casa cuando está borracho y tiene dos hijas a las que solo ve esporádicamente. César lo visita:

-Tío, vine para que me contés un chisme.

- ¿Qué será, mijo...?

—CCómo así que vos tuviste un hijo?

Gildardo desaparece momentáneamente y regresa con fotos. De ahí comienza su narrativa: en el marco de una conversación que es a la vez íntima y cargada de material etnográfico. Esta es una historia que escribe César sobre su tío -y su 
hijo Edison, ladrón que muere asesinado-; pero también es una historia de cómo César, llenando simultáneamente los papeles de sobrino y de etnógrafo llega a conocer a Gildardo y al resto de su familia. Historias de familia es, al fin de cuentas, la historia de cómo César emprende la obra de acercarse a su familia: es una historia de cómo hacer autoetnografía.

La experiencia autoetnográfica en Colombia resalta, sobre todo, el conocimiento indígena, transmitido a través de autobiografías a manera de testimonios, colecciones de mitos e interpretaciones de la cosmovisión. Estos géneros logran enriquecer la antropología nacional y nos recuerdan que las preocupaciones de los etnógrafos de antaño todavía son relevantes entre los lectores indígenas y nos destetan de la incesante obsesión por estudiar el conflicto que rodea a todos los colombianos, pues revelan la continuada necesidad de la gente que vive en medio de la guerra de hacer cultura. En Historias de familia César Augusto Tapias Hernández toma otro género de expresión autoetnográfica para empujarnos a llegar a la misma conclusión. Tal vez la abundancia descriptiva del cuento lo haga uno de los mejores vehículos para construir una autoetnografía de los sectores populares urbanos, porque nos conecta más íntimamente y con más urgencia con los protagonistas, haciendo en el proceso al etnógrafo un protagonista más.

Joanne Rappaport
Profesora del Departamento de Antropología
Georgetown University
Washington, D. C.





\section{De cómo un tío mío atracó a una tía mía}

"Póngale ánimo a la cosa". Élmira displicente y replica: "es que la cuestión no es de ánimo". Y suena una guitarra eléctrica: "Dinero... Angustias... Problemas... Dinero... Sistemaaa". Víctor Gaviria, Rodrigo D no futuro

La tía Irene les llevaba almuerzo a unas compañeras del trabajo. Eso fue un lunes después de día de madres. Había quedado de un sudado de gallina que se hizo en la casa, entonces había empacado un poco para las muchachas.

-Entonces ilo que te robaron fue el almuerzo, pues?

- ¿El almuerzo? Y un cheque de 60.000 pesos de un préstamo para hacer unos arreglos a la casa.

— ¿60.000 pesos que eran lo que hoy más o menos cuánto?

-Por ahí unos 200.000 pesos.

-Humm, mero gol el de mí tío $\mathrm{H}$, ¿no, tía Irene?

- Quien sabe, porque no lo cobraron...

De la Cooperativa dieron una orden de no pagarlo; además informaron el número de la cédula que también estaba en el bolso. De todas formas, había que esperar tres o cuatro meses para ver sí lo cobraban, no lo hicieron. Luego me dieron otro cheque.

-Y ¿cómo fue la vuelta, pues?

—Eran tres muchachos. A esa hora, 4:30 a. m. Fijo eran ladrones.

En esa época, años ochenta, muchacho por ahí parao en una esquina tenía que ser ladrón.

Veo que se vienen, y yo echo a correr. Yo bajaba por aquí (señala mi tía la calle); pero cogía pa' la otra calle, la de allá: a salir justo al paradero de buses de Castilla 263. Me agarraron, y uno de ellos me apercuelló y me puso la rodilla en 
la espalda. Arturo, mi marido, siempre me ponía cuidado y apenas los vio encima de mí, les gritó:

—iSuéltenla, pues, güevones!

-Yo no me acuerdo si había matorrales por aquí, o si esto era peladero. Uno de ellos dijo: "se vino ese negro gonorrea, jálale, jálale ese bolso...”. Me lo jalaron y salieron corriendo por ahí pa' bajo. Arturo era con la cantaleta: "con ese bolso tan grande, la van a atracar, la van a atracar, la van a atracar...” ¡ Y fijo me atracaron! Un bolso grande llamaba mucho la atención. De por sí a esa horas había poquito carro abajo, no existía otra ruta de buses y por aquí bajaba gente hasta del Picacho.

$-i$ A robar?

-No. A coger bus.

-Entonces la fila que había en el paradero era inmensa y en la carrera, los ladrones la partieron justo donde había un policía.

-Y el policía, ¿qué hizo?

— ¡Nada! Yo no puedo hacer nada señora, porque no estoy de servicio, fue lo que dijo.

Se salvó mi tío $\mathrm{H}$ con la suya, pienso, y recuerdo que en estos días un primo lo vio en televisión mientras informaban del hacinamiento en las estaciones de policía de Bogotá, y en una de tantas celdas agolpadas de presos estaba encanado H Tales.

-Yo conocía a todos los hermanos de su papá. Y a lo mejor él haya dicho algo en la casa de sus abuelos, porque los papeles míos aparecieron por ahí cerquita.

—En esas épocas, ¿de dónde salían los ladrones?

-De todas partes. No ve, pues, a su tío que venía de por donde su abuela.

-César, y ęusted ha visto que a uno lo atraquen y le devuelvan la plata?, dice la prima Lucía.

—...Espere, espere ahora me cuenta esa historia ¿̇í? Tía Irene, y ¿̇más o menos cuándo fue eso?

- ¿Qué es la preguntadera suya?, ¿va a ser una tesis con eso o qué?

- ¿Qué año era eso?, no más dígame eso...

—Como al año y medio de yo estar trabajando en Tejidos Wagner... 1981.

-Y usted, ¿se acuerda de cómo iba vestida ese día?

—Ehhhh, pero vean a este... Quizás de zapatos altos y un vestido de prenses...

—Oíste, amá —interrumpe de nuevo Lucía-, ese César va a escribir una historia con eso, póngale cuidado...

Mi tía Irene sonríe y llama a Arturo, su esposo: "Arturo vaya saque 500 pesos de la monederita y compre unos plátanos verdes”. 
Este primer relato surgió en la sala de mi tía Irene acompañados de los boleros entre noticias de la Radio Paisa: final de día en una sala acogedorcita. Estuvieron mi tía Irene, su esposo y primo Arturo, Lucía una de las muchachas y Sandra, la primera nieta de mi tía. La gran ausente: la televisión.

$\infty \infty \infty$

Estas historias de mi familia son como postales de diferentes lugares que, encadenadas para su lectura, dejan ver el viaje que hice mientras observaba y escuchaba historias de tíos y tías, de abuelos y abuelas, justo después de terminar la universidad. Fue un viaje por el recuerdo, por la memoria, por el amor, por el dolor, por los excesos... por todo aquello que me constituía como miembro de mi familia. Viajaba reflejándome en esas historias. Imaginando mi futuro tras esas historias. Fue un viaje alucinante y alucinógeno....Y no está mal ver como un viaje relatado las historias que a continuación encontrará; eso es la etnografía, un viaje y su relato. Sobre lo que se vivió. En torno a lo que se escribió. Las imágenes e historias que obtuve están transcritas en este libro, donde se relata un viaje de 36 escalas o relatos, cada uno de una extensión de no más de tres cuartillas, atravesadas por una reflexión sociológica en torno al lugar que ocupamos no solo dentro de la familia, sino como grupo en la sociedad. De joven sociólogo, quería entender cómo me construía la familia, y el lugar que ocupábamos en la sociedad que iba como en el lomo de un caballo desbocado entre los siglos Xx y XXI.

El ejercicio de reunir estas historias, este stock de conocimientos disponibles, se propuso para encontrar las palabras y los signos que como prenociones sobre la vida cotidiana de un grupo individuos ilustraran (no solo) un mar de problemas (sociológicos): anomías, malestares, por ejemplo, de los delirios de violencia, el abuso de alcohol y drogas, las rencillas familiares, etc., sino también solidaridades, y sobre todo amores: múltiples y coloridas representaciones que los individuospartes del grupo (mis familiares y yo mismo) hacemos de nuestro estado, de nuestras condiciones, del lugar que ocupamos con respecto a los demás. Pero, ¿qué trabajo conceptual o sobre qué líneas teóricas se desarrolló este viaje etnográfico? Más aún... metodológicamente, ¿cómo estudia un sociólogo a su propia familia? El lector se topará con interesantes referentes bibliográficos de espectros sociológicos, filosóficos, antropológicos y poéticos a propósito de la ebriedad, del poder, de la desigualdad de género y otras violencias, junto a la descripción etnográfica de los rasgos culturales de un grupo humano trasladado con los años desde el campo 
a la gran ciudad y unas claves metodológicas para comprender cómo es que se documentó tal hazaña.

Como profesional de las ciencias sociales suelto en las calles, me agarré de lo primero que entendí de mis lecturas en el metro, el llamado del sociólogo francés Pierre Bourdieu (2000), y lo que me correspondía hacer como científico social: demandar al razonamiento, a la revelación de las causas estructurales que las palabras y los signos aparentes no develaban. Intento con este texto, especialmente tras su lectura, hacer visibles los mecanismos que hacen que funcione el mundo social que construimos en nuestras familias, es decir, la estructura de la interacción que configuramos: mi familia en su forma de ser, un fenómeno social total de donde se derivan procesos como la comunicación y la expresión de sentimientos. Y me propongo este análisis, no para neutralizar los detonantes o causas de las formas anómalas que determinan nuestra interacción, ni para resolver los problemas que generan lo que somos. Basta con comprender las verdaderas causas del malestar que solo se expresan a la luz de la cotidianidad. Y de eso hay de sobra en este libro, una cotidianidad explorada y descrita bajo el paradigma cualitativo, utilizando la etnografía como metodología bajo la guía de tres claves posmodernas: 1) a la manera de los cronotopos de Lévi-Strauss (1997) en Tristes trópicos, las historias como configuraciones espaciotemporales construidas en escenarios ficcionales donde tienen lugar ciertos acontecimientos; 2) de la noción bajtiniana de carnaval (1953), en la que desaparece la diferencia entre sujeto y objeto, como resultado de la concepción dialógica del lenguaje, esta etnografía es una gran conversación, y 3) de la problematización de la autoridad y la escritura etnográficas mediante el uso del collage o montaje literario, intentando encarnar la vanguardia posmoderna entre Leiris (1934) y Taussig (2002), yendo de la actividad literaria a la práctica etnográfica que describe el viaje que he visto, y a mí mismo como soy. 


\section{De cuando Katherine vio a Dalí}

¡Guácala!, gritó un niño con cara de asco. Maestra Topolobampacracia, ¿hay ciudades que tengan árboles $y$ gallinas? La verdad, no lo creo. Francisco Hinojosa, Ana, ¿verdad?

"El manifiesto místico", para Dalí —recuerde, Kate, que se llama Salvador Dalí-, comenzaba una nueva era. Triunfa la mística y, con ella, la mística nuclear, cuya explosión se confunde con la explosión hacia un nuevo clasicismo. Como de costumbre, las noticias de arte propusieron maliciosamente la siguiente pregunta retórica: ¿no es imposible que en el sucesivo Dalí consagre más atención a lo consciente que a lo inconsciente? Si realmente fuera así, no le faltaría más que convertirse en el pintor académico más grande del siglo Xx...

Y Katherine, como nunca, supremamente atenta escuchaba y seguía por sí misma las palabras leídas y se dejaba llevar por los dibujos esos de un señor de largos bigotes llamado Dalí, quien en cualquier rostro pintaba el rostro de la mujer que amaba... Estamos en la biblioteca de la Universidad de Antioquia, pero cuando entramos le dije que aquí podría ella encontrar algo más que libros: "En este lugar es donde están todos los secretos del mundo, lo que querrás saber lo hallarás en un libro...."

Y Kate no dijo nada... Solo tomaba uno y otro libro y otro y les buscaba el derecho y les leía el título... desechando los que poco le interesaban, pendiente quizás de las formas, el tamaño de las letras o el olor entre sus páginas... Quizás la textura del papel...

- ¿Todos los secretos?

Me preguntó incrédula, y yo asentí. Había respeto y admiración por cada libro; eso se notaba en la forma como los miraba, los abría y los ponía de nuevo en 
su puesto para sacar otros... Y otros. ¿No querrás ver pinturas, Kate? Y dijo que más luego. Entonces le explique del porqué los libros tenían unos números y unas letras y quién los organizaba.

-Vamos, pues, por las pinturas — dijo.

De camino al otro lado de la biblioteca, no dejaba de admirarse por la cantidad de libros y por los computadores donde la gente buscaba... Antes que a Dalí, prefirió ver un manual de pintura al óleo, y cuando le pareció conveniente dijo: "muéstreme, pues.... Yo le mostraba algunas, alternándolas con historias sobre lo que Dalí quería pintar, aquello que en ocasiones a Kate no le parecía correcto, como los desnudos:

- Porque uno no debe estar desnudo en la calle - decía.

- Pero es solo una pintura, incluso la calle está pintada...

Muy rápido se pilló que cada pintura tenía un numerito en una esquina y entonces buscaba al final de cada página el número que correspondía a la pintura tal, y leía el título... Y sobre la que ella se detenía, yo le preguntaba: "Kate, decime ¿qué hay ahí?, ¿qué ves ahí?”. Y ella, con palabras y frases sueltas, decía algo más que cosas sueltas...

—Un árbol. Una copa. Señores peleando. Una Virgen... Una araña. Unos muebles volando... Humm. Mira, César, a esa gente se les voló la casa. Una niña cobijando a un perro.

- ¿Con qué?

- Con un tapete, ¿no ves?

- ¿Un tapete?

- Sí, un tapete de agua... Una mariposa con una boca como de otra mariposa... Se le está dañando el cuerpo a la gente.

-Y ¿cómo se llamará esa?

— ¿La 963? Per-so-na-je de ro-di-llas. Bo-ce-to (Boceto).

- ¿Ya viste ese reloj?

— Sí, se está dañando, como que se está derritiendo... y por los pulmones.

- ¿Por los pulmones? Y ¿dónde quedan los pulmones de un reloj?

-... En los números...

— ¿En los números? Ve, yo sí decía... y cómo se llamará ese.

— ¿El 964? El re-loj blan-do (El reloj blando)...

-Kate, decime, ¿qué es algo blando?

- Un pan, o un roscón... Algo así para que uno no se le caigan los dientes...

Y al final Kate supo cómo sonaban la $d$ con $r$ y la a: Dra. Y sí Dalí fue lo más grande del siglo Xx. Alegrémonos porque cada niño o niña, puede revertirlo y 
hacerse él o ella lo más grande del mundo. Con esa forma de mirar el mundo, el mundo se queda pequeño, y Dalí termina siendo un curandero de relojes que se derriten por los pulmones... 



\title{
3. La tía Emma, la hermana...
}

\author{
Las sociedades más dominadas por motivaciones religiosas son \\ aquellas en que se reconocen diversos misterios, \\ poderes, objetos y divinidades. \\ Bryan Wilson, La religión en la sociedad
}

Desde los tiempos del verdadero amor, extraídas mil sonrisas por puras evocaciones... las palabras surgieron hablando desde el corazón, confiadas como ayer en un correo. Hoy, sin temor, van confiándome sus recuerdos sobre el tiempo... Evocaciones.

Una noche, en medio de una buena comida, antes de partir a Estados Unidos, la tía Emma me fue contando que, de joven, de las cartas que le enviaban sus pretendientes algunos versos siguen grabados en su corazón. Hay que decir que quien evocaba esos momentos no era solo la tía religiosa de la familia, la que siempre reza por nosotros, la que venía a visitarnos cada tres años, a mostrarnos en sus ojos un pedacito del paraíso de los Andes. No, antes que nada, quien recordaba era la mujer que es por encima de todo. Y recordando iba como nube flotando sostenida por un viento de recuerdos, volando a las tardes olorosas a rosales donde a escondidas respondió una carta que definía su vida y el amor de un par de vidas y al amor mismo.

Pablo Peláez finalmente no se sintió tan mal al saber a través de una carta escrita por mi propia tía que quien le quitó el amor de su vida era Dios y no otro hombre sobre la tierra... Virgelma Fernández estuvo alistada en el Colegio de La Presentación teniendo apenas claro que no se casaría antes de los veinte años. Y nunca se casó. Y el día que lo decidió, devolvió a Pablo una foto suya, porque ya no tenía razones para tenerla... Y del pobre Pablo... cuentan que prefirió mejor jamás casarse y que pereció en un accidente sin ser de nadie. 
Virgelma o Emma, como quiera, pudo decidir qué hacer en la comunidad y prefirió la enfermería a la enseñanza, y así se convirtió en la primera mujer de la familia en ir a la universidad. Estudió en la Universidad de Antioquia por algunos intervalos durante los años sesenta y setenta. Desde siempre tuve la idea básica de que, un día, la tía habría tomado los hábitos porque sí, como iluminada... Sin más razones. Pero en realidad fue necesario hacerse monja para poder viajar a Perú o Bolivia, y conocer la alta planicie, cuna de grandes civilizaciones prehispánicas cuyos avances matemáticos y filosóficos no sobrevivieron al asalto del colonizador español. Un álbum-diario de viaje que había hecho la tía y que de algún modo terminó en mi casa era la razón de mis sospechas. Estaba ilustrado con fotografías de los lugares, de la gente en los propios escenarios construidos por los antiguos incas, acompañados con pie de fotos que indicaban qué ver en la foto. Por ejemplo: "Huerta en el convento de los padres franciscanos. Obsérvense las flores de Quina, se cultivan en abundancia en el altiplano, constituye una gran fuente de alimentación”.

Viéndolas me paseaba en el tiempo, me trasladaba a un viaje fechado en 1967, un viaje donde mi tía era más que una narradora, y se apartaba de la escena fotografiada de junto otras religiosas y uno que otro sacerdote... Miraba hacia fuera... hacia las flores... hacia dentro de los ojos de la gente, y con esos textos puntualizaba, como haciendo inventario del terreno... y los actores... Entonces recordé que los misioneros fueron los primeros etnógrafos.

Ese álbum fue lo que me permitió saber de una mujer seguidora de Dios entre nosotros, que un día se fue hasta muy cerca de las ruinas del imperio del sol, que era un dios en otro tiempo... Tal vez no fue a evangelizar, sino a vivir entre ellos y a terminar evangelizada.

Recuerdo las palabras de un amigo que hablaba de algunas personas y su capacidad de desplazarse a otros lugares a pesar de nunca viajar. La tía Emma regresaba a casa de sus padres cada tres años, y eso es un ejemplo de desplazarse físicamente... hasta donde nosotros; pero su viaje era y continuaba en el altiplano entre miles de hombres y mujeres que soportaban agrestes temperaturas... Y ahí estaba yo, siguiéndola en las fotos, sin dejar de pensar en esa gente que se le veía en apuros en medio de terrenos áridos... Eran rostros quemados por el frío, mujeres de trenzas largas y gruesas junto a hombres muy morenos, bajos, montados en caballos negros brillantes. Los indígenas aparecían con pómulos sobresalientes, ojos alargados; el contraste focal era mi tía y sus hábitos. De joven, mi tía Emma se parecía mucho a mi mamá... 
En otras fotos, un hermoso lago, las ruinas de Sacsayhuamán, donde el inca descansaba. Una canoa de totora. La transparencia del lago Titicaca, el más alto del mundo, $3812 \mathrm{msnm}$. Un torreón en Machu Picchu que me pone a pensar en la humanidad. Y una alpaca pastando en la sierra sobre la que quisiera acostarme a soñar. Autoridades del pueblito de Atoconcolla... Obsérvense los rostros de las autoridades.

El viaje de mi tía arrancó desde Titiribí a Medellín, de ahí a Barranquilla, luego a Perú, de nuevo Colombia; después Bolivia y de nuevo a Perú... Algunas veces se desvió a Nueva Jersey donde la familia... Con el tiempo se quedó en Medellín, donde sigue ejerciendo su enfermería con especialización en salud pública, dando además un mensaje de amor mientras acaricia y sana...

Las fotos... A lo mejor un día se le quedaron en casa... Ya de grande he pensado que estuvo bien haberlas dejado... Viendo sus fotos empezaron mis viajes.

$\infty \infty \infty$

Mi propuesta de recolección dialógica y polifónica trazó el camino para el delirio con que me opongo al realismo de las etnografías convencionales. Dialogando, fuimos construyendo este conocimiento etnográfico; dialogando intentamos comprender asuntos comunes y nos vimos obligados a poner de manifiesto nuestros puntos de vista personales, pues en cuanto sujetos históricamente situados que somos mis familiares y yo, logramos interpretaciones de nuestros mundos. Como diría Rabinow (1977), mediadas por la historia y la cultura. A la manera de Crapanzano (1980) y su encuentro antropológico con Tuhami en el Marruecos de los años ochenta, sin importar que Tuhami estaba loco... O de nuevo con Bourdieu (1989), sujeto y objeto de estas múltiples biografías (investigador y testimonios) tienen de algún modo el mismo interés por aceptar el postulado del sentido de la existencia contada (e, implícitamente, de toda existencia).

Recordar que la etnografía no es solo técnica. En cuanto método... la etnografía es escritura (Guber, 2001), y ese sentido es importante recapitular la crítica de Stephen Tyler cuando plantea que el diálogo vertido como texto ya no es un diálogo, sino un texto disfrazado de diálogo, un mero monólogo sobre un diálogo, en la medida en que las apariciones del informante del diálogo están por lo menos mediadas por el rol autoral dominante del etnógrafo (Reynoso, 2008). Sí y no. Para trascender las limitaciones de la representación, en ella misma debe estar explícita la negociación que hizo posible la conversación, las palabras que provocaron los recuerdos o las fotografías y las evocaciones que provocaron. 



\title{
4. i Que viva el presidente Tales!
}

\author{
Algunas realidades necesitan ser hechas ficción \\ antes de ser captadas. \\ Veena Das, en Nicolás Espinosa, Política de vida y muerte
}

-En este país, en este momento con la cuestión de la paz hay muchas falencias, creo que debemos contribuir cada uno, para mejorar... Debemos mejorar para que la paz sea un poco más completa. Lo que pasa es que en este país hay gente que cree que un país sin pobres es un país bueno y están... Cómo te dijera, están en lo falso, porque en un país tiene que haber pobres para que el país sea... relativo.

Y Martha interviene aplaudiendo y agrega:

-Mejor dicho, a ese político de esposo mío no le falta sino el pregrado, el posgrado, la especialización, el doctorado y la corbata.

—Je, je, je, je, je... —ríe el auditorio.

De eso de la corbata, ya se encargaba Fred, mi primo mayor, quien encuentra una buscando en el armario del papito Fonso...

Se trata de mi tío Hétor Mario y de su ebriedad... Y también de la Martha. Pero... ¿qué problema hay con estar ebrios?, bien lo dijo ya Baudelaire, el poeta mayor: "Hay que estar siempre ebrio. Todo se reduce a eso, es la única cuestión. Para no sentir el horrible peso del tiempo, que os destroza los hombros doblegados hacia el suelo, debéis embriagaros sin cesar".

No es exagerado atribuirle a la ebriedad, a la del licor sobre todo, y también a la de las drogas, y la de los celos... un lugar destacado dentro de lo cotidiano de mi familia. Y, bueno, la verdad, más allá de cualquier familia en especial, un lugar destacado en la gran mayoría de muestra sociedad, para bien o para mal... El Hétor, sin que nadie le hubiera dado bomba, comenzó a dar su discurso ante la cámara de video con la que Rigo graba últimamente cualquier reunión de los Tales. Esa cámara 
cada vez resulta ser otro elemento bien incorporado en nuestra vida familiar. Así, pues, sin importar la bulla de otros ebrios... ebrias también las palabras, el Hétor desenfunda las suyas...

Y yo estaba tras la cámara, ahí pegado en un primer plano, no solo para recuperar bien el sonido: palabras embebidas, sino para ver de cerca los ojos de mí tío Hétor... su rostro...

Entonces lo recordé caminando por los pasillos del INEM, ebrio quizás en aquella época de fórmulas de química y recordé también sus inmensos deseos por ir a la universidad, ebrio tal vez en esos días de curiosidad. Tan ebrio finalmente como yo de aquel instante...

Suspendido

Lelo

Viendo por la cámara...

Tan ido... que hasta Rigoberto, el dueño de la cámara (y del archivo visual de esta casa) creía que debía dirigirme, porque esos planos míos... Humm... Y yo me dejaba, ebrio en el instante...pensé: "¡Saldrían planos borrachos! Ve, corre un poquito la cámara, no te arrimés tanto... Coge mejor a Martha”.

Y Martha dejaba ver sus sonrisas y parecía más bien que las regalaba. Seguramente se ha tomado la misma cantidad de tragos que Hétor... Juntos comparten esta fiesta... También comparten el amor, un par de hijos y muchas peleas. Él hablando, ella escuchando, él asumiéndose al discurso y ella dándole besos... Fred apareció con una corbata y ya en la sala eran muchos más los que querían ver aquello y lo disfrutaron mucho, pero ninguno como el mismo tío Hétor y su esposa transformada ya en una periodista, preguntando: “QQué le falta a la paz, señor presidente?

Y el tío con las gafas de Fred y la corbata del papito, sentado en la sala haciendo carrizo e incorporando a su discurso la puesta en escena de sus manos, así como los políticos de ahora que se hacen llamar gerentes... Era el presidente Tales apoderado de la escena, quien contestaba:

- Lo que le falta a la paz es un acogimiento de todos los seres humanos, que tengamos una conciencia de reconciliación, que pensemos por todos, porque la paz es una globalización donde cada uno tenemos que poner su granito de arena...

-Y ¿ los desplazados, las víctimas de esta guerra?

-Yo creo que en la confrontación del país hay una falencia donde todos debemos aportar... Frente a los desplazados y los huérfanos, pues el país siempre se ha caracterizado por que las personas que más riqueza tienen siempre han vivido mejor que los que nada tienen... 
-Y Bush que no quiere a Colombia, ¿qué será del Plan Colombia?

-Bush al principio de su campaña siempre estimó apoyar el Plan Colombia, dónde están todas nuestras herramientas con las que vamos a trabajar todos...

- ¿Cuánto despeje espera darle a la guerrilla, todo el país, solamente la mitad, puede darles Cuba o Venezuela..?

-En estos momentos tenemos un problema con la gente de las FARC, ellos tienen un despeje hasta el 7 de diciembre, ellos se pronunciaron en esta semana y dijeron... muchas cosas...

Pero los asistentes, sobrinos, hermanos, la mamita, los espectadores del show, todos conservadores aunque liberados por el alcohol... lo abuchean: Buuuuuuuuuuuuuuuuuuuuuu

- ¿El 7 de diciembre? —alcanzó a decir uno en el público...

—No, este man no sabe dónde está parado — replicó otro— Ni cuándo está gobernando, sentenció uno más. Y la periodista le rescata de las garras de la "opinión pública”.

- ¿Hay que ser acaso como Fujimori?

-En estos momentos - continua el presidente, digo mi tío- este no es el mejor momento de Fujimori, porque su primera campaña se vio afectada por los aportes del narcotráfico, según lo publicó "El Osito", hermano de Pablo, en su último libro...

Y todo finalmente se hizo recocha. Pasamos de lo que bien podría ser el florecimiento del alma, desatadas las ataduras por el alcohol, a las inocentes risotadas de los que se pillaron aquella no tan extraña cosa: UN BORRACHO HABLANDO GÜEVONADAS. Y ¿qué con eso?, si hacía parte de la fiesta. Solo que esta vez fue un simulacro de un buen show nacional en vivo y en directo, con cámara incluida en caso de que resultasen interesados para una transmisión en diferido, con público y periodista a bordo, sobre todo la periodista... el presidente Tales ya medio enredado, hablando y hablando... Embriagados él y su esposa "para no ser esclavos martirizados del tiempo", cosa también dicha ya por Baudelaire... y tal y tal...

¿Que viva el presidente Tales!

Fulminante acusó la periodista y fin de la emisión.

$\infty \infty \infty$

Discurso, objeto, paradigma... Las teorías solo son instrumentos para indagar la "realidad", pero no son la realidad (Cajas, 2009); sin embargo, como coautor de 
la confección de estas viñetas, estoy tomando decisiones que no son neutras: ¿qué narrar y cómo narrarlo?, ¿qué esconder?, ¿qué cambiar?, ¿qué maquillar? Aparentemente no quiero interpretar. No quiero analizar. Solo describir. Espero me entiendan, pues como dice el dicho "es difícil hablar de la familia en público", pero como este libro le pertenece al lector, lo invito a intentar comprender el drama.

Si bien he planteado que este trabajo ha sido escrito en forma de montaje literario, a la manera del collage tussigniano, he procurado ir guardando el hilo de una experiencia etnográfica que busca abrir surcos o caminos a posibilidades de entendimiento que se abren desde la sociología para el estudio de fenómenos sociales. Lo que no se delimita claramente es la posibilidad de saber si los testimonios de este texto híbrido son textuales o se inclinan de alguna manera entre las delgadas líneas que van entre realidad y ficción. ¿Qué cree usted, amable lector? De ahí que sea una antropología que se enfoque en el desvarío de la alucinación, del enamoramiento, de una individualidad abrumada por la familia, institución autoritaria que le oprime y controla con la excusa de amarle, o ¿̇será al revés? ¿Que este experimento literario y antropológico me propone como el controlador sino de una experiencia, de su representación, y luego mis familiares me censurarán? Como Taussig, el antropólogo australiano vuelto jaguar en las selvas colombianas, creo que esta escritura trabada es un recurso contra el terror. ¡La familia es una maquinaria de terror! $\mathrm{Y}$ la escritura sobre ella es un recurso que me exige una forma otra de representación etnográfica... La evocación solo posible a la manera del discurso chamánico, de la poesía, del teatro, del surrealismo... Sí, esta etnografía es como una cura chamánica a la enfermedad social que conformamos, como una contra ante el terror de la vida diaria... Y contra la deconstrucción meramente académica que quiere explicar la vida de los salvajes (Reynoso, 2008). 


\title{
5. Yiyo: humo y brisa conjugada...
}

\author{
He visto más locos fuera del sanatorio (mira donde \\ quieras: almacenes, fábricas, oficinas de correos, tiendas \\ de animales, partidos de béisbol, oficinas politicas). \\ Habia un tipo absolutamente equilibrado. Podias \\ hablar con él sin problema, se llamaba Bobby, parecía \\ normal del todo. De hecho parecia más normal que la \\ mayoría de los comecocos que intentaban curarnos. \\ Charles Bukowski, Púrpura como un iris
}

Según le escuché a mi tío Jaime y a su esposa Teresa, "Yiyo" puede jugar billar con quien sea y ganar: "Pero a veces coge unas manías que hay que regañarlo — dice mi tío-. El otro día le conté que en un cuarto de hora se lavó las manos y la cara más de veinte veces, salía al balcón y volvía otra vuelta al baño... Nooooo".

Estamos en una reunión familiar celebrando la Navidad, y "Yiyo" ha comenzado a caminar por toda la casa de mi tía Irene: sale hasta el patio de enfrente, pasa por toda la sala hasta el patio de atrás, y puede hacer lo mismo muchas veces. No las conté. Viéndolo y escuchando los comentarios de mi tío, pienso en aquello de lavarse varias veces....

—Terminó con la cara roja — aclara Teresa.

Creo que lo que más importa de esa repetición del hecho en sí bien puede ser la ratificación de la negación del tiempo o algo así... La constante preparación para algo que no pasa, que no llega porque lo que importa... es... el trance, el tránsito, la pausa... Un momento fulgurante entre esta y la otra dimensión... Algo solo perceptible para el propio interesado, ya sea un drogata, un loco... Un Gómez Jattin, un H Tales, mi primo "Yiyo"... Otro yo.

No pretendo establecer un nuevo dictamen clínico sobre mi primo o la locura... La verdad, en este momento ni siquiera me interesa conocer lo que dicen los 
médicos. Por lo que yo veo, "Yiyo" es normal: hace un rato que llegó el sancocho al que fuimos invitados todos los Fernández, y saludó a uno por uno a los que allí estábamos, aunque guiado por Teresa; igual, servicio de compañía innecesario, porque Edison, alias "Yiyo", goza del aprecio de todos. A todos los reconoce y todos le ofrecen un saludo caluroso.

Después de un rato vi que se sentó a la mesa con la pretensión de jugar a las cartas, un "apuntado", según parecía, "bajando" como también le dicen a ese juego, y mientras todos discutían cualquier cosa como los puntos que llevaban, "Yiyo" barajaba las cartas como un verdadero sabihondo de la cosa ¿Tahúr es que llaman?: las separa en dos montoncitos que entrecruza rápidamente y una vez que tiene solo un montón, golpea todas las cartas contra la mesa para hacer del montón algo uniforme...

Tendrían que ver cómo repartió su "mano": de a cinco cartas inicialmente y al concluir la ronda, otras cinco, preguntando desde luego a quién le correspondían las once cartas... Fue la mejor "mano" de la tarde, un juego reñido, cartas bien barajadas. Seguía el juego y "Yiyo" continuaba en su mundo, suspendida la mirada en el vacío. Aun cuando yo estaba en su mira, no era a mí a quien miraba. Lo sé porque comenzó a hablar, y hablaba y hablaba con alguien que no era yo, no eran para mí esas palabras, aun cuando yo estaba en su mirada. Vi que se impacientaba por ratos; pero volvía a calmarse y era inevitable que los demás lo miraran e interrumpieran su juego.

Mary Luz, una de las hijas del tío Gilda, lo sacaba del trance donde estaba para enseñarle su juego, y "Yiyo", como si nada, inmediatamente sabía qué carta tirar, y de nuevo al trance... Yiyo recoge otra carta para Mary; pero como no le sirve al juego que ella tiene, la deshecha... Y otra vez...

Le escuché a Teresa que un día le pegó a "Yiyo", a causa de una de esas manías y le pegó de forma insistente (¿así de insistente como es él con sus manías?). Obviamente, según ella, fue una "pela” moderada... Y, sin embargo, el Yiyo finalmente le dijo: “Te te te te te estás eeeeenloqueciendo ooo qué, mamá..., dddddejá de pegarme!".

"Yiyo" siempre ha tenido dificultades para hablar: medio gago, medio pegado, quizás sea algo más grave que su andadera repetitiva, pues no le deja expresarse bien; pero la muestra — disonante para los “normales" — de su estado alterado es que camina y camina. Así, pues, parece que en todas las áreas de su conducta, de no ser por esa cosita de caminar de un lado a otro, hablando unas veces, moviendo su cuerpo extrañamente otras, Yiyo es como usted y como yo. Lo de moverse puede 
verse como algo simpático; pero siento que es algo que "Yiyo" finalmente tiene que hacer. Confieso que a veces lo hago yo también. "La locura se calma caminando", sostiene una amiga.

Un vecino de mis abuelos afirma que a "Yiyo" lo rezó una vieja. Cosa más absurda no había escuchado nunca. Junto a la casa de mi abuela, "Yiyo" tiene primos, de esos seres presumidamente convencidos de su "normalidad" y que se creen en capacidad de censurar otras actitudes y entonces rehúsan su presencia y no le abren la puerta cuando él los visita... No pueden ocultar su antipatía. Insisto en que, además del caminadito, "Yiyo" es normal. No entiendo la actitud de la gente, pero sí logro entender el embeleso donde se ubica la mente del primo... Y me parece lógico, se enajena de la absurda rutina de todos nosotros. "Yiyo" logra derrotar la engañosa apariencia de la realidad y de cuando en vez baja a nuestro nivel para complacernos con su presencia, entonces nos regala una sonrisa. Pero se rehúsa a los cuestionamientos, porque a lo mejor ya lo sabe todo: mientras los demás nos movemos entre dudas y mentiras: apéndices de nuestra existencia: dudas y mentiras, mentiras para nosotros mismos... Él flota en su verdad, la repetición...

"Yiyo" sigue desconectado de nosotros en medio de la caminata que a tantos preocupa, sabiéndose etéreo y mágico... Como todos podemos también ser, ¡si pudiéramos desconectarnos...! Él, yo... Nuestras miradas... Aquella tarde donde mi tía Irene éramos viento y humo, respectivamente. Conjugados, revoloteábamos por allí siendo poesía incomprendida, centro de teorías descalificantes que dicen que estamos locos... 



\section{Tensionarte-trazos de Wbeimar}

¿De qué sirve polemizar con la nada? Ya es hora de serenarnos, de triunfar sobre la fascinación de lo peor. No todo está perdido.

Emil M. Cioran, La tentación de existir

Hombre de cabello negro, como de indio. De faz alargada y bien delineada. Tus chaquetas y botas... Tus ojos. Tus manos muchas veces ocultas, pero victoriosas. ¡Hay cosas que la muerte no se lleva! El ángel guerrero, el de espada gigante, va montado en su unicornio de músculos fuertes y patotas grandes. Demonios de cuernos largos y con barbas muy negras reciben rayos que matan: deseo de vida aniquilado por la maldad... En la sala de donde Efigenia, un cuadro de Wbeimar parece consagrar al amor una falsa victoria sobre la maldad...

Wbeimar era el menor del matrimonio entre el también difunto tío Gilberto, y la muy joven aún Efigenia. Los otros dos hijos son Claudia y Fredy. Hace un par de meses el primo Wbeimar fue asesinado de la manera más absurda y, por desgracia, también la más común. En los barrios populares y despojados de cualquier realidad nacional como el tropel ente "paras" y guerrilleros", nos matamos de a poco para controlar unas cuadras, y mostrar un poderío ínfimo pero devastador, hablando al mundo de un honor estúpido... Honor fundamentado en miradas frías y vacías, que con palabras secas y disparos certeros ordena el mundo al amaño de unos pocos...

Así, cualquier humano que en medio de la noche se sienta dueño hasta de la noche misma, puede desenfundar su arma y disparar... seguro de que el caído era una gonorrea del otro combo... pero seguridad nunca puede haber...

Wbeimar se fue así, porque otro lo decidió. Y se quedaron inconclusos muchos de sus trazos: mujeres desnudas rodeadas por demonios; un paisaje para Efigenia, una rubia de ojos cafés fumándose un puro, objetos y formas expuestas a la luz y su firma, una W (doble u) sostenida entre tensiones que se contraen, a la manera de 
fuerzas encontradas que van chocando unas contra otras, dando forma a algo, a él mismo... A él y su arte.

El primo Wbeimar era para muchos un ser extraño. Una vez Efigenia comentó que hasta desconocido por algunos en la misma cuadra...

- Un día resultó metido en todo aquello del rock — cuenta su hermano Fredy - con amigos artistas y artesanos también, y se parchaba mucho en el Parque del Periodista, y dibujaba cosas extrañas que bien le podrían costar la excomunión... Su círculo de amigos eran puros hombres... Yo sí preferí la salsa, y las niñas... Otra rumba, entonces ya grandecitos todo fue un choque entre ambos. Terminamos hablándonos lo necesario.

Y la vida es así: termina uno por hallarle el sentido cuando todo ha terminado. Como si la muerte fuese necesaria... Pier Paolo Pasolini (1971) tiene un ensayo hermosísimo sobre eso... "Es absolutamente necesario morir — dice- porque, mientras estamos vivos, carecemos de sentido...".

Fredy reconoce que, a la final, los roces que tuvieron fueron cosas sin importancia, Wbeimar le cogía sus cosas, y eso al Fredy no le molestaba, siempre y cuando las cosas volvieran a estar en su lugar, y eso era lo que no sucedía. Quizás la pelea última haya sido por un encendedor... Esa historia de disputas y pocas palabras, se parece a la de mi hermano y yo... Nosotros también terminamos hablándonos apenas lo necesario. Triste.

Mientras Fredy terminaba de vestirse para ir en busca de unas cervezas, yo lo esperaba en la sala de su casa viendo ese cuadro de Wbeimar: pintura llena de azules y naranjas... Vi también la placa que acreditaba su talento en la pintura y un par de fotos suyas en el diploma del colegio y el certificado de un concurso donde estuvo Wbeimar cuando era un pelaíto al que ya se le notaba la fibra de artista... Sonaba salsa romántica con un sonido espacial, un poco brillante el acorde de coros sobre los ritmos también brillantes. Era un equipo de sonido viejo, una grabadora de disco compacto y par de parlantes como monstruos negros a los lados....

- Hey, Fredy, ¿qué es lo que tenés aquí montado?

- El equipo funcionando como un amplificador — responde Fredy-. Al equipo llega la grabadora, dos parlantes de 300 watts cada uno y tres twitters... ¡Mero sonido!, ¿no?

De lo que se trata, para que entiendan, es de un equipo de sonido Motorola que tienen en esta casa desde hace unos veintiséis años, los que de casados según Efigenia. El equipo tenía una entrada y una salida para los bafles, dos superparlantes que bien podrían amplificar una orquesta en vivo, los twitters según percibo, dan el brillo 
ese tan notorio. Ya me gustaría escuchar de ese modo, bien duro y bien brillante la mejor pieza de SALSA: "Vámonos pa'l monte”, de Eddie Palmieri (versión en vivo). Pensé en decírselo al primo, pero como que lo sospechó, desde un principio y me fue repitiendo que el equipo ese no funcionaba, sino como amplificador, ni radio, ni tornamesa... Qué falla pensé yo.

El primo Fredy cursa actualmente el tercer semestre de Trabajo Social en la Universidad de Antioquia. Preferiría él estudiar ingeniería de sistemas, pero no se apura. Hoy le interesa el trabajo social, y saber eso ya es bastante. Piensa en la ventaja de la interdisciplinariedad de su carrera, por cuanto debe coger algo de las demás ciencias sociales...

—Eso está bien — afirma el primo- Necesitaríamos de un nuevo Freud en la universidad que establezca esto como ciencia y lo pruebe de una forma tal que las demás ciencias no nos hagan falta.

Y más allá de todo eso, le complace ver a mi primo que el nuevo perfil del trabajador social es mucho más intervencionista ahora:

- Antes era puro asistencialismo y uno estaba en los hospitales para rebajarles la cuenta a los pacientes de bajos recursos. Hoy puede ser uno el líder, el que convoque o impulse el trabajo de un grupo o comunidad; se trata de hacer, de estar metido en la formulación de los proyectos, vamos a ver... Ojalá.

Y, más allá, el primo dice que eso de las humanidades le favorece a uno en lo personal, pues tiene uno que hablar más y decir qué es lo que está pensando, que dizque adquiere uno más conciencia... Dice él.

- Qué iba yo a saber qué era el capitalismo o el socialismo... Es en la universidad donde se da uno cuenta del mundo y después ves las noticias hasta distinto...

Dos años hace que murió el tío Gilberto. A mí, por lo menos, siempre me pareció un tipo lejano, como Wbeimar, silencioso. Sin embargo, era especial... Como al tío Gildardo, le gustaba tener el cabello largo; pero era muy malgeniado y eso desesperaba a todos, aun cuando nunca se metió con nadie. Y Fredy, otra vez como cualquier ser humano, haya el sentido de la vida del tío, ida ya la vida del tío...

- Cómo no iba a estar malgeniado mi papá con ese trabajo...

- ¿Qué hacía, pues, el tío?

- Trabajar en la construcción. Pero había días en que se le notaba contento, era cuando le caían trabajos de electricidad...

Fredy tiene pinta de cachivachero o marañero; eso se lo aprendió al tío Gilberto. De niño, pillaba mi primo cómo el tío desbarataba y armaba electrodomésticos, y lo acompañaba algunas veces, a regañadientes, a las casas donde el tío tenía que 
arreglar la luz... Hoy, Fredy desbarata una moto y vuelve y la monta de nuevo. Así como pillaba al cucho camellando, pillaba al mecánico y entonces esas cosas por la que pagaba ya las hace él...

-Primo, y ètú mamá...?

- Mi mamá es puro amor. Navega en un mar de ingenuidad y entonces cualquiera se la convence, pero es de puro amor por los demás...

$-\mathrm{Y}_{\text {¿Claudia? }}$

- Mi hermanita es muy inteligente, pero muy elevada, hermano...

-Dispersa podría ser la palabra apropiada... ¿No crees?

-Podría ser...

Del primo Fredy podría decir yo que es un tipo abierto al mundo. La U le pegó donde era y seguro le pegará todavía más. De esos golpes son los que uno necesita... Y aspira él, sin afán, estudiar sistemas, electricidad o electrónica... Y en cuanto al trabajo social, le gustaría irse más bien por el lado de las organizaciones, los conflictos en las empresas y todo aquello. Le teme un poco a la tesis, pero yo le digo que eso es hasta bacano, la confrontación siempre es necesaria... y gratificante después de todo... Así parecen levantarse los trazos del desaparecido primo Wbeimar: tensiones que se contraen. Y nos es que yo me lo haya inventado ya, no. Entre los bocetos del primo está el borrador de su firma: las curvas que conforman sus líneas tienen flechas que se encuentran, y con letras pequeñitas, el primo escribió muchas veces la palabra tensión...

Tensión debió haber entre ellos dos: Wbeimar y Fredy... Tensión la que dejó el Wbeimar como regalada a su hija, una nena que con mínimos años ya raya los cuadernos haciendo "píos", tensión su mismo arte falleciendo ante el arma implacable del hombre que le disparó sin preguntar... Tensión aún tensa en sus obras inconclusas... Quien quita que hasta su niña un día las termine... Tensión era el mismo Wbeimar... Hombre de cabello negro, como de indio. 


\section{Yo no sé, hermano, es una orden...}

Ante la colosal magnitud de la crisis, esta experiencia, bajo una de sus formas que es el miedo, está siendo utilizada como instrumento de dominación en la pretensión de doblegar los

sujetos ante instituciones que ya no le dicen nada a nadie.

Carlos Jiménez Caballero, Desobedecer para convivir

JF Tales se llama mi primo... Le decíamos "Mordillo" en un grupo juvenil donde terminamos con su hermano Fred, el primo Camilo y yo; pero todos en la casa le llaman "JF", quien después del colegio decidió irse para la policía...

Riiiiiiiiiiiiiiiiiiiinnnnnnnnnnnn. Riiiiiinnnnnnnnnnnnnnn. Riiiiiiiiiinnnnnnnnnn (suena el teléfono):

-¿Aló?

- ¿Entonces qué, el civil...?

-Entonces, qué, primo...

-Ve, vos que sos bueno pa'l discurso... Necesito escribir sobre un tema cualquiera... Es para la revista de la Policía y hay que entregarlo el fin de mes... ¿Me vas a ayudar?

Desearía que la escritura se convirtiera en un verdadero y próspero trabajo, decía Tsushima Shuji, el poeta maldito japonés, "una ocupación de hombres sin ningún brillo.... No importa, con tal de escribir lo que yo quisiera....

—¿iPara la poli!?, ¿qué tal este poemita?: el monstruo comelasbasuras y las basuras... Y un niño montado justo ahí sobre las fauces del animal mecánico... Rrrrrrrrrrrrrrrrrrrrrrrrrrrrr... Meloniando el animal mecánico y el papá del niño sosteniéndolo justo al lado donde uno de los trabajadores del camión pone unos tacos de madera con puntas y clavos... Papá e hijo a un lado de la boca blanca esa... Al lado de la basura. Al parecer no han leído en la calcomanía amarilla-pequeñita que dice en inglés, precaution... y ellos ahí, como si nada... 
-Y eso ¿qué significa?

-Mmmmm... mira, es necesario tener más información, qué publica la revista, por ejemplo, no sea que mandemos cosas bien extrañas...

-Como las tuyas, güevón...

- Lo siento, relaciono a los polis con monstruos...

-Y lo del papá y el hijo, ¿qué es?

-Vos, vos y tu hijo...

-Mejor el poema de las puñaladas...

-Humm... Las 39 puñaladas.

- ¿Cómo es que dice? Qué pesar del pelao ese, pero quién lo manda, uno se equivoca y no falta el que corrija...

-Ay, primo... A veces me asustas más con tus propuestas literarias... que lo que tengo que ver como policía.

- ¿Te parecen indecentes mis poemas?

-No. ¡Simplemente son malos!

- Juan, matemos la luna...

— ¿Estás trabado o qué?

-Demos un paseo por las estrellas... ¿vamos juntos a torear a la locura?

- ¿Me vas a colaborar o no?

- Transcribí esta conversa si sos capaz, pues...

-Aaaa, ¡mucho marica!

-Te quiero mucho, ome, "mordillo", lagrimeo si te lo digo de frente...

Más bien vení cuando querás a contarme tu vida de poli, pero no vengas vestido de poli. Ya sabes que los polis me caen muy mal.

-Entonces ¿qué mandamos a la revista?... Oe...

$\infty \infty \infty$

La primera característica experimental de esta etnografía ha sido el uso de la observación participante como principal herramienta del trabajo de campo, combinada con otras técnicas, como la fotoprovocación, una manera de explorar la realidad que se vivió en tiempos pasados, mostrándola/contándola por medio de representaciones (Tapias, 2012); y dos tipos de entrevistas, la etnográfica (Guber, 2004), que nunca nos llevó grano o al meollo de los asuntos problemáticos, sino que nos permitió, como a los borrachos, desvariar... Y la entrevista narrativa (Schütze, 1983), que se trata de una narración sobre la vida personal del entrevistado, sin pre- 
via preparación. Este rigor metodológico me permitirá pasar del objeto sociológico que son al principio el grupo de seres humanos, ubicados en la realidad histórica que es mi familia, al discurso sobre ella, como el objeto científico de esta antropología. Un discurso sin mucha coherencia eso sí, lleno de conjeturas, de suposiciones, de imaginaciones... de trabas.

Para decirlo con el mismo Tyler (1986), un discurso revelado en la paradoja y en la persuasión a los lectores a través de conjeturas opuestas a las lógicas o lugares comunes del discurso científico... Emulando a los sociólogos William Thomas y Florian Znaniecki (1996), quienes en lugar de usar fuentes públicas como registros oficiales, noticias de prensa o discursos gubernamentales, optaron por documentos personales producidos por los mismos sujetos para escribir sobre campesinos polacos que emigraron a Estados Unidos; relatos orales que en esta ocasión son coproducciones de las partes que forman el sistema social observado, y del que solo capté palabras. El verdadero análisis subyace en comprender las condiciones de producción de esas palabras, de esas imaginaciones, de esas ficciones... La etnografía misma, la autoetnografía que enmascara (mi preguntadera), en las instantáneas dialogales en que se constituye cada historia.

Entre las primeras preguntas que motivaron este análisis tenemos, ¿cómo ver en una familia las estructuras y formas sociales que la componen en plena interacción? Más específicamente, me preguntaba: ¿cómo son las relaciones entre las parejas, padres e hijos, entre hermanos y entre todos con la abuela? ¿De qué manera intervienen las características de mi familia, sus costumbres y creencias en la manera de relacionarse? ¿Cómo media la vida urbana y su antigua vida en el campo en nuestras relaciones familiares? Así, este proceso etnográfico construye un inventario de valores, de repertorios, de competencias, de todos los conocimientos disponibles proporcionados a los actores por el complejo cultural que adquieren con la práctica, y con los cuales construyen estrategias de acción para negociar sus identidades a lo largo de la vida. Un stock, diría Schütz (1974), para este caso etnográfico y experimental que da cuenta de una autoetnografía donde soy conarrador de mí mismo y de mi familia. Y lleva el apellido de experimental, por cuanto busco innovar en la escritura etnográfica, a través de cierta tendencia a pensar el texto como un cierto tipo de guion o libreto cinematográfico, confeccionado con base en cuadros o escenas muy breves: viñetas, planos secuencia independientes que aspiro a que el lector "componga" en su mente, mientras va leyendo el texto. Ahí está la herramienta clave para visibilizar las negociaciones estratégicas, comunicaciones no (siempre) verbales que nos permitirán comprender el drama del ambiente do- 
mestico antioqueño de un grupo social de clase media baja que evoluciona en la última mitad del Xx: la familia individual moderna, que desde el siglo XIX, Engels, el teórico clásico del socialismo, denunciaba como fundada sobre la esclavitud doméstica más o menos disimulada de la mujer. 


\title{
8. La mamita Gélica
}

\author{
La muchacha que habia franqueado la montaña porque se \\ habia sentido impelida por una esencia interior nueva, formaba \\ parte de las cuidadoras del agua. \\ Doris Lessing, La grieta
}

Fue por una mojada muy tremenda que se metió estando acalorada. En esa época, dice ella, andaban muy mal. "En esos días se me murieron las chiquitas: Aura Rosa, Luz María y Martha Elena y un varoncito llamado H. ¡El primer H!”.

Una de ellas había estado muy enferma y la abuela toda decidida y sin importarle nada distinto a sus hijos fue a llevarla al hospital. Un carro las llevó en la parte de atrás hasta San Cristóbal. Ahí fue donde se mojó... Las cogió un aguacero en el camino.

-Fonso nos había dejado por irse con otra vieja por allá donde trabajaba. Francisco, un hermano de él y yo, lo vimos. Era una que había sido dizque muy amiga mía... Desde eso no dejé entrar más mujeres a esta casa.

Mi abuela y sus hijos vivían en Bello, por los tejares, al lado de los papás de Fonso. Por aquellos días en que el amor iba dejando de ser, o se iba haciendo otra cosa... don Guillermo, el suegro de mamita, les pagaba el rancho. El viejo Guille como que era muy buena gente. Sin embargo, fue doña Abigaíl, su mujer, quien muy solidaria corrió a darle a mamita Gélica una bebida de sauco, cebada, caracucho blanco y malva cuando lo de la mojada esa, pero se la dio fría, cuando tenía que ser caliente. Y la abuela es reiterativa con esa sentencia: "Me la tenía que tomar era caliente, no fría, como ella me la dio...".

Esa, según dice la mamita, fue la razón que le dio el doctor sobre su eterna enfermedad: "pa'l pecho cualquier cosa tenía que haber sido caliente". 
—Desde ahí, fue que empecé con esta asfixia, porque antes nunca la tuve. Yo no nací con eso.

— ¿Gélica, vos pensás que tu suegra te quiso hacer mal?

-Yo no sé. Pero tan raro que ellos siempre que venían me dejaban enferma... Toda la semana siguiente quedaba mal y hasta me tenían que hospitalizar.

A la mamita entonces se le volvió costumbre con los años ir al Seguro Social por lo del asma, y aunque varias veces realmente estuvo muy mal y la hospitalizaron, ella prefería no dejarse coger ventaja y, así fuera sola, cogía un taxi y se iba en el momento menos pensado si es que se sentía más mal de lo normal... Es que normalmente el baño de la mañana la molestaba un poco, pero ella sola se componía a veces, sentándose en la mesa de la cocina, en su puesto junto al fogón, dándole la espalda a la ventana que da al patio de la casa de abajo... Pero otras veces tenía que irse rápido adonde el médico. Y si de pronto llegaba y había mucha gente esperando turno en urgencias, para no esperar mucho, mi abuela tosía y tosía, fingiendo un poco la voz y la ausencia de aire y se lograba entrar a la sección de nebulización. Allí la sentaban y la ponían a inhalar droga; digo, medicamentos. Al ratico salía riendo y me mandaba hacer la fila para reclamarle los remedios... Ya dizque la había visto el doctor y listo. Muchas veces podía regresar a la casa de inmediato. Otras, se quedaba hospitalizada, preocupada por los quehaceres de su casa.

En aquellos malos días cuando murieron algunos hijos, hasta el tío Miro llegó a estar muy mal, lo único que podían comer era "Agua sal". Las cosas mejoraron un poco solo cuando Fonso se colocó en las Empresas Públicas. Al papito yo siempre lo vi muy responsable, sobre todo cuando mis primos y yo éramos niños. No había diciembre que no nos diera carritos de aguinaldo, pero mamita dice que fue que doña Abigaíl quien lo corrigió, y eso porque hasta ella tuvo que demandarlo. Le embargó el sueldo. Solo así empezaron a superar tan mala racha. Ya en la casa de El Pedregal, el acomodo de tanta gente fue aparentemente sencillo. Instalados en casa propia, Melia, Hael, Rubiela e Ilsa dormían en una habitación, de a dos en cada cama. Alberto y Miro, H y Raúl en otra, igual, compartiendo camas, Will y Hétor en la piecita de adelante y el niño con los cuchos en la habitación. El niño era Ed... el niño, siempre al lado de mi tío $\mathrm{H}$, el diablo. De $\mathrm{H}$ dice la mamita que cuando lo bañaba, lo sacaba afuera a asolearse y se le volaba, y se le paraba encima a gallina, un vecinito hijo de doña Filomena y se le orinaba encima... "H era malo-malo desde pequeño y enfermo por conseguir plata”.

Tanto que sacaba cualquier cosa y la cambiaba o buscaba la forma de venderla... de hacerla plata, y de la escuela mandaban a cada rato notas porque les robaba 
plata hasta a las maestras... y que a los ocho años se metió donde un vecino y se sacó un reloj...

Quizás sea difícil de imaginar una casa con tanta gente y con ciertas "joyas" entre los propios hermanos... Y los tropeles, la cantidad de tropeles que debieron de haber tenido. Cuenta Gélica que fulano no le daba plata a mengano y por eso este lloraba, o que a zutano no le gustaba que perano se le pusiera su ropa. Sin embargo, el bullicio de aquella época lastima a la abuela, aun cuando es solo un recuerdo ya. Hoy después de tanta gente... de tanto tiempo, se ha quedado sola. Hasta el papito Fonso con los días se desvaneció, dejó de existir...

Su esperanza siempre fue Ed. Mi abuela, igual como esperan los claveles el rocío, siempre esperaba que estuviera ahí con ella; pero Ed también se esfumó...

-Ed debe de estar flotando por ahí. El haber sido tan malo no debe permitirle aún entrar al cielo, entonces está como esperando...

Hoy la casa está vacía. No la habita ni el ruido de la tele fantasmal encendida... Recuerdo cómo la noche la sorprendían ya dormida: la tele encendida y mamita dormida esperando-descansado... Mamita sonríe con los ojos llorosos sopesando las imágenes de ayer y de hoy contrastadas, atosigándose en la memoria de los años. Y así en el transcurso de una tarde, Gélica recuerda a cada uno de sus hijos con sus verdades...

—¿En qué lugar estará $H$ ?... ¿ Tendrá frío?

Una madre no deja de pensar ni en el hijo más calavera... como recuerda al más diablo de la casa; tampoco olvida al que bien podría haber sido el más juicioso de sus hijos: Hétor Mario.

-Qué pesar. Él no tuvo más que remedio que casarse.

La abuela no hizo sino criar hijos, y nietos... dice, y recuerda que en pago, papito ni ropa le volvió a dar... La veo sentada ahí, junto al fogón, hablando de sus días, de sus años... Años hace que es mi mamita y, sin embargo, siempre parecía estar estrenando nietos de tantos hijos que tuvo. Tantos que cuando trata de llamarlos, a hijos y nietos, los confunde llamándolos por mil nombres, nombres diferentes en vez del correcto, adivinando, retando a la memoria, a los años. 



\title{
9. El segundo nombre de mi mamá es Inés
}

\author{
Dispénseme usted, señora... me sería penoso que usted me \\ encontrase mal educado... no la he saludado antes, aunque me \\ parece, por no decir que tengo la seguridad, de que ya nos hemos \\ encontrado otra vez. \\ Lajos Zilahy, Las cárceles del alma
}

Hay cosas que se le graban a uno en la cabeza, como recuerdos habitados por nostalgias, idas, afectos enredados, días de colores, imágenes como fotos de hasta olores que se quedan detenidas en la mente; pero otras definitivamente las asume uno como marcas bien afinadas hasta constantes: posturas, pensamientos, actitudes, que le otorgan identidad a lo que será uno... De los primeros, tengo yo uno bien bonito: una vez mi mamá me contó que se presentó a la Universidad de Antioquia, quería estudiar enfermería; aunque hoy, creo, debió de pensar mejor en economía, negocios o administración, y eso me lleva al segundo caso. Mamá desde hace mucho tiempo organiza natilleras: forma más popular de ahorro con énfasis en la consolidación de la comunidad, jamás he conocido.

Aunque se evaden de los bancos justificados en el tres por mil y otros tipos de impuestos, desde siempre es claro que plata reunida, prestada al interés y repartida al final con ganancias y divisas... es también, además del desvare en un fin de año, salvación en cualquier momento para el ahorrador que sin muchos trámites recibe un préstamo facilito, de pronto firmando una letra y ya. Y ahorrando así, semanalmente, la gente se atrasa y entonces debe pagar multa... Y ahí está mi mamá cobrando.

"Y mejor que se atrasen bastante, porque por ahí se va haciendo plata", dice mi mamá: Rubiela Inés Fernández Quiroz. Ella es quien propone y organiza las rifas, los paseos y demás actividades de modo que le sumen a la cuota semanal... de la que llevan registro tanto los socios como mi mamá. Registros en libreticas y cuadernos argollados... Un sistema computarizado enredaría la cosa. Mamá de gafas sentada 
al comedor, su cuaderno lleno de cuadros, uno por cada mes, divididos a su vez en cajones: las semanas del mes numeradas del uno al cincuenta... Ahí anota las cuotas pagadas y lleva el registro de los préstamos e intereses. Como recuerdo también tengo que a mi mamá no es que le guste mucho su segundo nombre. A mí por lo menos me parece hermoso. El Inés como tal me trae a la mente a la mamá Inés, a quien le canta "Bola de nieve" un negro gordo cubano, mientras acaricia su piano: “todo lo’ negro' tomamo' café ay mamá Inés... todo lo’ negro’ tomamo' café...”.

Y mencionando el café en la cancioncilla esa, recuerdo el café de mamá, sobre todo el que prepara de sobremesa para la comida la más de las veces. No he probado otro igual. Pero es que detrás del café hay mucho más: la primera lección de cocina, de sobrevivencia, más bien, que a mi hermano y a mí nos dejó mamá: montar cada día, temprano en las mañanas el agua de panela. AGUA DE PANELA para el chocolate, AGUA DE PANELA, un poco de leche y la cantidad precisa de café, de modo que no perturbe el sueño. Y aun así medio disuelto el café. Termina uno y en el fondo de la taza huellas de nuestro producto nacional. De más pelao me armaba figuritas, unas manchitas regadas ahí no más... aunque me quedaban mucho mejor las que hacía con los restos de chocolate: flores, mariposas... y las flores terminaban comiéndose a las mariposas. Lo del café era como otra técnica y tenía su truco... El chocolate es, sin duda, mucho más manejable.

Bueno, volviendo a los negocios, mi mami se arma constantemente propuestas para procurarse un billete, y ahí va uno delineándola... Si bien eso no le han dejado fortuna económica alguna, nunca se la pilla uno fuera de base: siempre tiene algo por ahí pa' desvararnos salvándonos de quincenas tan largas... Si no que lo diga mi papá. A mí, por lo menos, desde 2000 pesos para un pasaje al centro, 200.000 y algo más para tiquete aéreo a Cuba, un millón y tanto para una película o el primer capítulo de una novela... Su franquicia es ella misma: no fue a la $U$, pero las ganas de estudiar no se le agotan: peluquería, panadería, arreglos florales, culinaria y mucho más... Y en eso se encarreta ella, y hace de lo que aprendió y lo vende, o enseña y al hacerlo cobra: decoración de piñatas, elaboración de velas, arreglos navideños... Eso es lo que le da unos pesitos, puro estudio... Lo último si bien no le ha dejado ganancias económicas, tal vez sí muchas espirituales: la Biblia. No es pastora ni nada de eso; solo hace las lecturas en algunas misas y estoy seguro de que, como ella, pocas con la misma convicción y entrega... Mamá es muy creyente, y nunca ha protestado por nuestra poca convicción, aun después de insistirnos mucho en la religión, ¿resignada? No sé, eso sí más tranquila porque nos confía a su Señor. 
También la recuerdo mucho cuando en las tardes oía "Pase la tarde con Caracol". Se dedicaba a mirar sus flores en el patio... La habitaba en aquellos días cierto amor: correteaban sus pelaos por la casa, y ella era feliz. Pero al final, creciditos ya, nos dimos a corretear fue por las esquinas y calles del barrio, y a la cucha de a poquito el sueño le quitábamos... Un día me encontró un superfierro metido entre mi ropa: un trabuco calibre 16. Y ¡lloró mi mamá! La sorprendía el hijo que tenía. ¡Estaba probando cucha!, preferí mejor las palabras y las películas, me estoy haciendo palabrero y cineasta... (Sí, sí estoy matando gente; pero en los cuentos)...

Siempre en la noche mi mamá buscaba el sueño frente a la televisión y me pedía que, por favor, no lo apagara. Su soledad en aquel cuarto no la aguantaba, aunque jamás lo confesó. El poeta panameño Rubén Blades parece cantarle a mi mamá en "Las cuentas del alma”, y yo me imagino cantando esa canción en algún café famoso solo para ella. Ha pasado el tiempo y un poco más grande, me veo un poco altanero con el destino: sus hijos seguimos teniendo una madre joven con ganas de ser todavía... Y nos pelea y nos pelea aún por el desorden... Todas las noches se va a dormir temprano. Al otro día ameniza sus mañanas con la radio encendida en las noticias... Lee también mi mamá, pero ya no tanto como antes, satisfecha seguro de que el vicio ese lo cogí yo... Le interesa de vez en cuando darse otros aires: sentada o recostada en el sofá, despide algunas tardes con un café caliente como pasante a los suspiros que, encontrados por las palabras, las palabras mismas le regalan durante sus lecturas: "las pestes" de Camus, algo de Capote y algunas novelas a las que ha renunciado espantada por los nombres raros: Las cárceles del alma, del húngaro Lajos Zilahy: "Era un día de septiembre; las siete de la tarde. Desde las colinas de Buda, oíanse los lamentos de un tárogato que parecía cantar un adiós al verano”.

Son los recuerdos finalmente lo que nos llenan la existencia. Ahora mismo sé de uno que a mi memoria ofrezco acompañado de un son cubano: "Mamá, yo quiero saber de dónde son los cantantes...”.

Eso es lo que siempre busqué en los discos, de dónde eran los cantantes. ¿Desde cuándo compro yo discos, Inés? ¿Recordás, por ejemplo, mi inquietud por la música instrumental? Estando muy pequeño me compraste un long play de villancicos. $\mathrm{Al}$ angelito de la carátula lo miré durante todo el viaje de regreso a casa; se parecía mucho a mi hermanito Carlos.

“¿De dónde serán? ¡Ay, mamá!” Los cantantes, los embusteros palabreros (los etnógrafos)... ¡Ay, mamá! ¿De dónde serán? 
Sobreviene la pregunta respecto a ¿cuál es el grado de efectividad de este mensaje sociológico?, respondería que... solo quiero hacer/conocer nuestra forma social de interactuar, de ser, de vivir. Y este hacer/conocer remite a un asunto metodológico con implicaciones políticas: cada repertorio de conocimientos fue obtenido conversando, no interrogando ni siguiendo un cuestionario establecido. Se trató de un ejercicio etnográfico que incluyó, además de su escritura o transcripción, la lectura posterior entre quienes la hicieron posible. Un ejercicio de reflexividad que nos permitirá maniobrar con mayor libertad a la hora de seguir siendo parte de este mundo. 


\title{
10. El tiempo / en el amor / y / sin él
}

\author{
A Homero le gustaria narrar otros dolorosos detalles que ha \\ mezclado con su profunda amargura, pero sabe que tantos \\ llorarian al oírlo y tiene piedad de ellos y los omite. \\ Raúl Gómez Jattin, Homero
}

Un día temprano por la mañana, cuando salía para el trabajo, mi tío Willi se encontró en la reja que separaba la casa de los abuelos de la calle una nota que entre líneas desmemoriadas, borradas por la infamia de los años y la rabia, le decía que él no era hijo de mi abuelo. Y él, todo lleno de rabia, fue y le dijo a la mamita un poco de cosas feas que aún hoy le parecen feas y le da hasta cierta piedra el haberlas pronunciado... Y a pesar de la pena, nunca se disculpó porque "En la casa... eso de pedir disculpas nunca se practicó. Pasaban las cosas y nadie volvía a decir nada. Normal”.

Cuentan en el barrio que mi abuela Gélica era muy celosa con el papito Fonso. Y que por eso tuvo grandes diferencias con vecinos y vecinas. Verdaderos problemas. La abuela acusaba, los acusados respondían. Considerando eso, entendió con el tiempo la nota que una mañana lo dejó abrumado. Las intenciones. Los reclamos. ¿Cómo habrán sido los reclamos en aquella época? Pasó el tiempo en casa de mi abuela y a la final eso ya no importó. Como cuando la tarde pasa a hacerse noche. Entonces imagino la calle que conducía a casa de mis abuelos, invadida de sueños, sueños sin mesura, y llenos de groserías... y a mi tío huyendo del lugar. Fugándose. Buscando amor... intentando salvarse.

De entre los hijos de la abuela, el tío Willi fue el primer afiebrado por las motos. Lo recuerdo trabajando la mensajería en su moto, una Kawasaki roja... Me parecía que volaba, rapidísimo, como toreando al viento que quería despeinarle su cabello... y colgados en el viento... dejaba besos para sus admiradoras, untados del humo azul de la gasolina quemada. Pero, de pronto como cualquier gacela, 
siempre fácil de agarrar a pesar de la carrera, la fragancia de una rosa le sedujo... El Willi enamorado terminó casado, pero al poquito tiempo, pasado el amor, el amor perdió... Se separó, siguió correteando el viento:

- Me casé con Rosa, pero ella no paraba la tomadera de trago y las fiestas con sus hermanos casi a diario... Y me iba de ella aburrido, pero volvía además humillado, porque la quería. Y llorando le decía: mañana será domingo pa’ mí, mañana será domingo pa' mí... Un día, coincidieron la aburrición por ella y un buen trabajo: la opción de arrancar otra vez, entonces me abrí...

Con hija a bordo, Willi regresó a trabajar en terrenos conocidos, una agencia de viajes de un mancito-mafiosito que lo necesitaba así de pillo y de rapidísimo como se veía en su moto roja. Entonces su entusiasmo salió del taller, rompió de nuevo el viento y hasta se dejó embriagar por el aroma de una nueva flor.

De donde vivió con su nuevo amor, recuerdo que sobresalía un almacencito que se atendía por la ventana y dejaba ver mil variedades de las mercancías que pueden encontrarse en una miscelánea, cuchillas, adornos, cosméticos y unas pequeñas obras de arte que María Eugenia, la flor del nuevo aroma, pintaba con colores inventados de otros colores, paisajes realistas que adornaban cerámicas pálidas-revividas ante sus ojos... Y al fondo de la casa, resonaba una sonrisa larga, sin pena, brillante, la de Vanessa.

Era otro Willi que con el tiempo, y rodeado de margaritas, dejó las motos para mejor montarse a los carros. Así, en un auto particular o uno de servicio público, como fuera, se la pasaba buscándose las carreras de arriba abajo, y esperando con esperanza entre semáforos y cruces con glorietas, que le saliera un viaje pa'l otro lado. España o Estados Unidos... "Y no es por goma o simplemente porque todo el mundo se va. Yo no veo posibilidades de progreso aquí, pelao”.

Juliana, su hija mayor, la que tuvo con Rosa, de trece años para cuando escribía esta historia, ha querido irse a vivir con él, aburrida también de Rosa y sus rumbas; pero siendo como Rosa, según dice el mismo Willi, "No vive conmigo porque... de pronto sí me voy, no puedo dejarle esa responsabilidad a María Eugenia... ¡Mejor no, que se quede con la mamá! ¡Son iguales!”.

El viento mejoró y cuando Rosa vio que Willi no solo no regresaría, sino que tenía otro jardín... Lo buscó y no dudó en pedirle perdón, pero el Tales, orgulloso y lleno de motivos, fue inclemente, con severidad como si él fuera el destino, le fue diciendo: “¡Hoy es Domingo para mí!”. 
Queremos, dice Estanislao Zuleta (1994, citado en Gutiérrez, 2013), un mundo de seguridades y tranquilidades, amores eternos, verdades firmes, nichos seguros. "Deseamos mal". Esto es fuente continua de intolerancia y males sociales, y de la incapacidad de desarrollar nuestras propias potencialidades individuales. En la sociedad actual, cuyo seno observamos para culpar a la familia de casi todos los males... Ese ideal pedestre inevitablemente empobrece y bloquea el progreso "sin descanso" hacia "una altísima existencia" (Goethe, 2009). Deseamos no solo una buena familia, sino un buen trabajo, y que no hayan más conflictos en torno nuestro. Yo mismo mientras escribo padezco de la angustia de vivir como he podido... Pero mantengo el deseo de mejorar. Sin embargo, ante la pregunta de este gran ensayo por las relaciones entre el sujeto y la colectividad, en una sociedad por demás injusta, basada en la explotación y en la dominación de clase, recuerdo las palabras de Primo, el personaje que abre la etnografía de Bourgois (1995): "Vendiendo crack en Harlem": "Man, I don't blame where I'm at right now on nobody else but myself ", 1 pero mi lugar en medio de los demás es un lugar en medio de estructuras de poder que apenas podemos ver... La familia y nuestro lugar en ella... La lucha diaria por fuera no es solo la familia la que nos oprime... Es la sociedad que se confecciona en la familia.

1 "Pana, yo no culpo a nadie aparte de mí por la situación en la que estoy". 



\section{La huelga del 69 (primera parte)}

Existe un movimiento continuo de crecimiento de las fuerzas productivas, de destrucción de las relaciones sociales, de formación de las ideas dominantes; lo único inmutable es la abstracción de ese movimiento. Carlos Marx, Miseria de la filosofía

Sin duda, esta es una gran historia: de policías y correrías, de amenazas y medidas extremas, de filiaciones casi comunistas luego reivindicadas como errores, la historia de Jaime "Pereque" Fernández, una historia al menos para mí, deslumbrante, una hasta donde el presidente de la República resultó implicado: la huelga en Peldar.

-A uno lo elige la asamblea de trabajadores afiliados — dice el tío Jaime—, así como en cualquier elección. Hay unas planillas con unos nombres, y eso escoge la junta directiva del sindicato; luego, ya entre los elegidos, que son doce, se vota por los puestos: hay cinco miembros principales, cinco suplentes y dos más, quienes asumen la vigilancia.

- ¿Una especie de veeduría o qué?

-En esa época se conocía como junta de vigilancia. Yo entré a Peldar en el 59, más o menos, y la primera vez que me eligieron fui secretario.

- ¿Segundo al mando o qué?

-No, primero estaba el presidente, luego el vice, el secretario era el tercero, luego el tesorero y el fiscal detrás. Pero también llegué a ser presidente, incluso. El sindicato ya había negociado un sueldo de tiempo completo para ese puesto, así que uno no trabajaba propiamente en la empresa, pero en las labores sindicales y la empresa igual le pagaba...

Pero en la huelga de 1969, el tío Jaime era el secretario. Como cada año, el sindicato elaboró un pliego de peticiones para negociar con la empresa. Allíse proponían los aumentos, las primas, los auxilios, en fin... Dice don Jaime que buscaban, 
por ejemplo, que los empleados participaran de las utilidades de la empresa cuando la producción fuera buena, que la empresa mantuviera los fondos para auxilios de vivienda, etc. Ese proceso se llevaba a cabo, dentro de lo normal, a través de las etapas conocidas como arreglo directo, conciliación, prehuelga y hora cero. En aquella oportunidad se agotaron los tres primeras, y se decretó entonces la hora cero...

Por medio de unos papelitos se le informó a cada trabajador la hora de parada, hora que los mismos ejecutivos de la empresa conocían... La negociación sería responsabilidad de unos delegados; dos por parte de la empresa, otros dos del sindicato y uno o dos del gobierno, nombrados en la oficina de trabajo...

Cuando yo llegué a casa del tío Jaime, sin mentir... en busca de esta historia, se me ocurrió preguntar de inmediato por el presidente Lleras. Y mi tío decidió no faltarle al desarrollo cronológico de los acontecimientos; así que mientras que en la licuadora picaba los mangos para los bolis que fabrica, vende y distribuye, yendo de un lado a otro: de la cocina al patio y viceversa, como su hijo Yiyo, andando de un lado a otro... me iba contando que la ley dice que las huelgas se desarrollan afuera de la empresa, en unos campamentos donde deben permanecer los afiliados; pero que, realmente, en la huelga de 1969 se cometieron errores, y reconoce, además, la influencia de un muchacho comunista.

- ¿Qué clase de errores, tío?

-Pues... ¡nos tomamos la empresa!

Normalmente, los negociadores salíamos a las oficinas que quedaban en el centro; pero cuando nos tomamos la empresa, eso se llenó de policías y soldados, y ya no podíamos salir de allí. En tres días acabamos con la dispensa del restaurante y ya luego las mujeres terminaron tirándonos panela por encima de los muros... La negociación continuaba, pues donde estaban todos los trabajadores, y mentiras...

-Como no se llegaba a ningún acuerdo, el plan era secuestrar a los negociadores de la empresa como para forzar la cosa... ¿ ¿Me entiende? Otro error, indudablemente. Y cuando paramos los intentos de conciliación y nada de nada, resolvimos colocar parlantes por toda le empresa y apelar al terrorismo psicológico:

- Vamos a prender la empresa... VAmos a acabar con todo... La cosa fue tal que la gente del barrio de la estación se subía pa'l parque de Envigado por puro miedo a que todo el sector estallara... Nosotros negociábamos en una oficina y los miles de empleados dentro rodeándonos. Ese era el cuadro. Los tipos nos decían que los dejáramos salir, que continuáramos al día siguiente y uno de nosotros iba y les decía a los compañeros: "compañeros, ¿qué si paramos hasta 
mañana o pasado?; ¡que ellos salen y vuelven!”. Y los compañeros, que no. “¡DE AQUí NO SALE NADIE!".

- Hombre, esto es un delito... esto se llama secuestro... apenas decían ellos... estamos cansados, tenemos hambre...

-Y nosotros respondíamos que también estábamos cansados y que también teníamos hambre; pero que nada de nada, el canto de los compañeros era “ ¡ACUERDO! ¡ACUERDO! ¡ACUERDO! ¡ACUERDO!

-De entre los que estaban dentro estaban el alcalde de Envigado y un delegado del gobierno nacional. ¡Ah! Y otro más del sindicato, porque según los negociadores nosotros éramos muy sectarios y hasta complicados. De pronto, como si nada, aparece el portero llamando a Óscar Betancur, el presidente del sindicato.

-Don Óscar, que pase al teléfono...

Al rato Óscar llama a mí tío y le dice:

-Oíste, que pasés al teléfono.

-Y ¿eso? ¿Quién es?

-Donde el presidente de la República...

-Yo paso y el señor me dice: “don Jaime Fernández, ¿sabe con quién?”.

-Pues el compañero me dijo que usted dizque era el presidente.

- Sí, señor - contesta él, y de una va como mandando.

- Me hace el favor. Si a las doce de la noche no me salen todos de allá, los saco cadáveres.

- Pero yo no puedo sacar a la gente así no más - le decía yo- Nosotros también estamos encerrados por los trabajadores; no se trata de hacer lo que nos da la gana... Y bueno...

— ¿Cómo que no? Si yo soy el ¡PRESIDENTE DE LA REPÚBLICA!

— ¿Ah, sí? Sí, sí, claro; pero... es que también está el pueblo, como mínimo los congresistas quienes aprueban las leyes sobre las que usted se mueve - le respondía yo.

- Vos cómo que entendés mucho - me decía él...

-Y yo diciéndole que, así mismo, yo no podía hacer nada... que todos los compañeros también estaban dentro...

—Páseme al fiscal —y yo se lo pasé; pero él le dijo lo mismo.

Así suspendimos la negociación en un momento donde ellos subían un poquito y nosotros rebajábamos. Se cedía de a poco, pero nada de acuerdo. Entonces decidimos parar. Ya en medio de esa amenaza, qué íbamos a discutir. A los señores con quienes negociaban los dejaron libres finalmente; pero libres de salir de la 
oficina esa, porque los trabajadores estaban decididos a que los sacaran a todos según el comentario del señor PRESIDENTE DE LA REPÚBLICA, ¡cadáveres! Así, que entre todos movieron los buses de Peldar y los atravesaron sobre los rieles del tren que en aquella época entraba hasta la empresa, y también buscaron candados y cadenas para cerrar bien la puerta...

Ya el tío se desconcentró picando mangos, como medio consciente de su labor, pero embebido en el recuerdo, picó y picó y picó tres veces el mismo vaso de mangos cortados. No los bajó de la licuadora para luego pasarlos por el colador como había hecho con un par de tandas inicialmente, solo se acordaba y prendía de nuevo la licuadora con los mismos mangos y se enchufaba otra vez a la historia... Me dio como pena - es la verdad-. Comparaba al tío con Yiyo y sus acciones repetidas... pero era por contar la historia que se interrumpía su trabajo; ah, pero qué va, el relato resultaba muy interesante... Mi tío Jaime entregado de lleno a la evocación...

- Pasaban las horas, y nosotros veíamos desde adentro cómo aumentaba el pie de fuerza: ambulancias, bomberos, un tren repleto de soldados y perros policía... Llegaron las doce en punto y se vino una grúa delante del tren y pa' dentro. Levantó esa puerta de una y se llevó esos buses por delante, y se llenó eso de policías y de soldados en un segundo, y bueno... nosotros con palos haciendo escándalo y corriendo por esa empresa... Yo corrí con un amigo y nos metimos por el alcantarillado y de allá nos sacó un perro. Todos cagaos vueltos nada... Resulté encanado allá en Envigado. Todos los miles terminamos presos: unos en Bello, otros en la Ladera, en Itagüí y en Envigado. Al otro día nos ubicaron a los principales de la junta y nos llevaron adonde un inspector quien se responsabilizaría de la investigación fruto de la cual habría despidos y presos por los delitos, es decir, los errores cometidos... por el momento teníamos que pagar 30 pesos por cabeza, es decir, por cada uno de los miles, para poder salir de la cárcel y volver al trabajo al día siguiente.

- ¿Esos 30 pesos hoy serían cuánto?

-Unos 30.000, diría yo... 


\title{
12. La huelga del 69 (segunda parte)
}

\author{
La cohesión del grupo era contra los jefes; ahora hay una \\ adhesión de obreros contra obreros. \\ Pierre Bourdieu, "Hamid", en La miseria del mundo
}

El tío Jaime apenas pudo regresar a casa desde la "cana", como a las cuatro o cinco de la tarde: "Todo cagao, mal oliente".

Al otro día, se suponía que les esperaba de nuevo el trabajo, a él y sus compañeros... ¡ Vaya sorpresa la que se llevaron! A los dirigentes del sindicato, principalmente, el portero no les permitió la entrada: mientras a la empresa ingresaban todos los demás, Jaime y sus "compas" esperaban afuera.

- Entraron todos y con las que nos salió el portero era que firmáramos la tarjeta y que volviéramos a las dos a firmar otra vez la tarjeta. Así nos la pasamos varios meses, recibiendo el sueldo sin trabajar, jugando billar por ahí cerca pa' alcanzar a ir a firmar...

Pero no crean que lo del presidente de la República queda agotado con la llamada telefónica que él mismo hizo a Peldar el día de la huelga. Quedó claro que las intenciones eran despedir cerca de 400 empleados, cosa que no autorizó el gobierno nacional, que solo quería la cabeza de los dirigentes sindicales de cada una de las sedes de Peldar, pues la huelga de 1969 bien podría llamarse la huelga mundial, como a ella se refiere Teresa, la esposa del tío, pues las plantas de Barranquilla, Zipaquirá y Envigado protestaron al mismo tiempo. El problema (y la pelotera) fue en el ámbito nacional, y la solución también debía serlo entonces. Así las cosas, continúa Jaime "Pereque" con el relato de una historia que hizo escala en la Casa de Nariño:

- Le pedimos una audiencia al m... ese, y nos la dio. Nos estuvimos en Bogotá como ocho días. Uno va a una oficina en el Palacio de Gobierno, y en una oficina se tramita la solicitud que el presidente acepta solo en casos especiales. Nos acep- 
taron, pero no a todos. Entramos solo tres, cada uno representando a una planta: por Barranquilla, un moreno grande llamado Douglas; de Zipaquirá, no recuerdo el nombre del tipo, y yo, por la de Envigado...

-Y ¿cómo era Lleras?

—Un cabecipelado él, bajito, malacaroso.... malaclase.

-Les acepté la audiencia solo porque quería conocerlos y pa' que me vieran. Digan lo que digan, aquí no hay arreglo, ustedes van para afuera — dijo el presidente.

—Pero, doctor —intervino Jaime - usted no puede hacer eso, ¡echarnos!, se formará de nuevo el tropel ese, los trabajadores están dispuestos a todo.

-Yo asumo las consecuencias — dijo el señor presidente- y fin de la reunión.

Cuenta el tío que la reunión con don Lleras fue a las 11:00 de la mañana y a las 4:00 de la tarde ya estaba en Medellín. La siguiente parada era la empresa para pasar un informe a los compañeros y ver qué se hacía. Si bien no se aprobó el despido masivo, el de los líderes era un hecho. A través del portero de la empresa mandaron llamar a sus representantes adentro. Como no podían entrar, otros dirigían la cosa. La idea sí era atacar de nuevo; pero los de adentro rindieron informe: "por lo menos unos cien soldados están aquí como desde la 1:00 de la tarde...”.

Esta historia está siendo recreada treinta y punta de años después en el patio de una casa donde se habita y se trabaja. Y Teresa, la mujer de Jaime, haciendo lo suyo en la cocina, pero toda conectada a la evocación, trasladada a esos tiempos, contribuye incluso en la composición del relato:

-Mientras estos venían, el viejo ese se les adelantó y les llenó la planta de policías y ejército...

—No había remedio - retoma don "Pereque" —. Y para ajustar, el portero nos entregó la carta de despido firmada por el propio presidente de la República; pero eso no es todo; no había opción alguna de recomendación para otra empresa. Ahí sí... ¡se cagaron en nosotros!

Sin embargo, aquello fue noticia nacional y unos compañeros suyos comenzaron a ir los días de pago a otras grandes empresas como Tejicondor, Fabricato, la FLA, Coltejer, etc., pidiendo colaboración para los compañeros despedidos de Peldar, y se recogían un platal el hifuemadre que entre los despedidos se repartía...; pero eso no fue cosa de mucho rato, la gente se cansó de dar plata.

- Jaime empezaba a decir que vivíamos era de limosna — sonriente cuenta Teresa- Con el tiempo nos tocó arreglárnoslas solos...

Terminó por aquellos días administrando el tío un negocio que papito Gabriel montó en la América, recién llegado de Estados Unidos. 
- Popalito, un amigo mío, me dijo un día que yo estaba en una foto allá en la gobernación tachado de sindicalista revolucionario. Mejor dicho, si eso hubiera sido hoy, iya nos hubieran matado!

Finalmente, como dice mi tía Irene y la prima Omaira, el tío Jaime se dio el gusto de ser echado por el mismísimo presidente de la República. Una situación que hoy en día él contempla con sonrisa; pero sin evitar que sus ojos se chocolateen. Debe de habitarle la tristeza y la frustración a mi tío Jaime, alias "Pereque", como le dice su esposa. Y es que atrás, más allá de más de diez años consagrados a una empresa, quedaron amigos y una situación que, sin duda, debió de enseñarle bastante.

Y más que haber conocido al presidente, a mí personalmente me asombró ese dato del tío, su capacidad de mirar todo, con obvia nostalgia, pero sin dejar de reconocer errores, algo que no es solamente de ahora 30 años después... De regreso a la planta, el mismo día de la audiencia con el presidente Lleras, los dirigentes pensaron en sus compañeros, y siendo honestos prefirieron dejar las cosas así como iban, ¿para qué pelear más?...

El tío no pudo ubicarse de nuevo en una fábrica; pero no por eso se quedó ahí. Digamos que el tío es hoy una especie de microempresario donde el único jefe es él y sus trabajadores son aquellos (familia o gente cercana a veces) que rentaron sus locales de ventas de comidas rápidas, y evitándose así, de paso, que le monten un sindicato. Y hasta de pronto, que le hagan paro.

$\infty \infty \infty$

Las etnografías dependen de la naturaleza de la audiencia. Esto aplica en casi todo el libro si pensamos que la audiencia primera es mi familia, y ante ellos mantengo el compromiso de posibilitar una comprensión diferente de las cosas, como para ir más allá de comparaciones con manifestaciones de sorpresa. Todo cuanto hay aquí no nos sorprende. Este viaje, esta etnografía, este cuento largo... solo ha descrito mi traslado desde la pregunta inicial hasta el intento de su comprensión, de forma similar a cómo Marlow remonta el río Congo en busca de Kurtz (Conrad, 1899 [1996]).

Sin embargo, esta etnografía también está pensada para los colegas y demás investigadores... Es un documento para contribuir a historiografiar no solo la cultura, sino la forma de abordar el objeto... Desde ahí debo decirles que, como Marlow, fui testigo de experiencias extremas, yendo al corazón de las tinieblas. Esta etnografía debe verse como el registro de un proceso emergente, remontando un 
caudaloso río lleno de dudas, de preguntas, de experiencias que, una vez escritas, intentan transferir esas dudas al lector... Es más que una reseña familiar específica: propone aspectos de los miembros de un complejo grupo social en un momento determinado, un grupo humano que ha estado viviendo en el mundo antes de que yo apareciera con mis preguntas, y que continuará viviendo después de cerrar este libro.

En síntesis, es una etnografía en función del grupo estudiado (Agar, 2008), de sus valores: datos perfectos, objetivamente obtenidos, reescritos a manera de memorias, de poemas... y... la interpretación antropológica que resulta es ficcional, sí, una ficción en el sentido de que es algo "hecho", algo "formado", algo "compuesto" a partir de recuerdos facilitados oralmente, en intercambios más o menos simétricos, discursos autobiográficos que, como dice Gramsci (1975), documentan molecularmente la explosión social, o en palabras de Bourdieu (1989), ilusiones biográficas no necesariamente falsas por ser imaginadas, mucho menos inefectivas. Son un experimento de escritura, que me permite afirmar con Geertz (1973) que lo que primordialmente hace un antropólogo es escribir. Y eso he hecho: desvelando las formas invisibles de cómo funciona la estructura social que conformamos. Recordar que soy miembro del grupo observado, un narrador no protagonista pero involucrado... intentado crear una evocación... y lo que ha terminado por construir, son fragmentos de sus vidas, sus cambios históricos, que una vez relatados, parecen cuentos inventados pero que en realidad son el resultado de escribir sobre su cultura.

$\infty \infty \infty$

Observar la cotidianidad de los personajes durante este viaje constituyó una posibilidad metodológica; pero la resolución de las preguntas solo fue posible de forma dialéctica, contradictoria: mostrando qué es una cosa y qué no lo es (¿quién soy y quién no puedo ser?). A partir de las interacciones con mis familiares y la escritura de las viñetas o historias de este inventario, recurrí a los aportes de varias teorías.

Para comenzar, Norbert Elías (1983), quizás el filósofo social más completo, para quien el objeto de estudio de la sociología es la interdependencia de los individuos: la sociedad como un tejido cambiante y móvil de interdependencias múltiples que vinculan recíprocamente a los sujetos. Mi hermano, sus aprendizajes, el taller de mi papá, mi papá... su violencia, mi mamá, yo... mis tíos, el barrio, el guaro, las drogas: tejido social, configuración social, sistema social, formas específicas de interdependencia entre nosotros mismos, red de intercambios, de intersubjetividades entrelazadas y la mayoría de las veces desequilibradas, porque aquí también existe la 
desigualdad, la dominación y el poder desquiciado junto a formas morales y éticas por construir. Y ni qué decir de la violencia como un recurso para esa construcción de lo social. Incluso la violencia emocional. Ya se trate de héroes, bandidos, sabios, mujeres solteras o con hijos, abandonadas u olvidadas... me parece que es la violencia la que consolida la unión del habitus como historia hecha cuerpo, y del campo como historia hecha cosa, el mecanismo principal de la producción del mundo social (Bourdieu, 2000): conjunción, movimiento, interiorización del exterior y de exteriorización de lo interior. Es lo que llamamos en sociología salidas dialécticas sobre repertorios ampliamente difundidos entre diversos sectores de una sociedad, saberes intergeneracionales que se mantienen como ecos que naturalizan lo aprendido. ¿Qué es ser hombre? ¿Qué es ser mujer? ¿Cómo serlo y cómo dejar de serlo?

$\infty \infty \infty$

Hasta 1860, ni siquiera se podía pensar en una historia de la familia. Las ciencias históricas hallábanse aún, en este dominio, bajo la influencia de los libros de Moisés. (Engels, 1884) ¿Por qué no escribir la historia de una familia? Más aún... ¿las historias de mi familia? Era allí donde podía contrastar la realidad con mis inquietudes frente a elementos que constituyen el mundo social contemporáneo. $\mathrm{O}$ ¿cómo explicar la articulación de las formas sociales pasadas con las formas sociales nuevas? ¿Cuáles son unas y otras? ¿Cómo se conjugan las herencias y la obra social cotidiana? Esta etnografía se convierte en la posibilidad de ver el fenómeno de la familia cerrarse un poco a poco sobre sí mismo. Mi familia confrontada sobre sus repeticiones, sobre sus configuraciones. Porque pensar la familia como una categoría sociológica implica considerarla más que como institución (Corcuff, 2005), como una estructura social en movimiento, plena de interacciones, es decir, una acción social, una experiencia vivida, un acto no necesariamente contemplado reflexivamente; pero en camino de serlo, y como tal, posible de desarmarse, to strip, diría Goffman (1974), pensando en cualquier fenómeno social (adecuadamente) delimitado y contra el cual el etnógrafo (yo mismo) pudiera poner a prueba su comprensión, considerando como centro de análisis, para el caso de este libro: la intersección entre lo colectivo y lo individual.

¿Es posible aislar lo colectivo de lo individual? (¿Mi forma de ser contra la de mi padre?) A este respecto, Émile Durkheim (1895 [1975]) continúa siendo una referencia obligada, ya que su idea de lo colectivo remite a la idea de presiones exteriores impuestas a las personas y a un ámbito de validez que trasciende las conciencias 
individuales. Es la inconclusa obra inédita de Alonso Buitrago, un sociólogo colombiano inédito que se pregunta por hijos sin madre, por padres sin hijos, por amantes sin remordimientos. ¿Cómo ser unos hijos de puta que no necesiten la familia para no venerar la esclavitud? (Buitrago, 2012) Sí, es que somos esclavos formados en la familia. De ahí que las madres se crean dueñas de sus hijos. Es de locos. La familia es de locos. Y mi familia no es la excepción. Está conformada por locos de amor, de entusiasmo, de aguardiente, de rencores, de dolores... Creo que para avanzar nos viene bien modificar aún más los estados de la conciencia, así que la siguiente invitación es a embriagarnos, como lo propone el gran poeta del siglo XIX, Charles Baudelaire: "embriagaos de cualquier cosa”. Incluso de la realidad, acotaría una instructora de yoga. 


\title{
13. Mi hermanito o la danza ebria
}

\author{
Toda la noche nos la pasamos llorando y bebiendo, y pude \\ decirte borracho las cosas que me bullian del corazón... \\ John Fante, Pregúntale al polvo
}

Me contaba un profesor de antropología que en India danzar es diferente a bailar. Para lo primero, el cuerpo era nada sin el alma, que agitada debía verse en la danza, de tal forma que no es lo mismo ver la música poseyendo almas, a ver cuerpos sudando en medio de la pista... El alma de mi hermanito se agita, encantadora y sonriente, adornada por dos huequitos que le deja la sonrisa en cada mejilla. Sonriente, mi hermanito se esparce en una noche de farra, aguantando todo el guaro que la noche le brinde, siendo a la vez la danza ebria, danza seductora, armada de una sonrisa, la sonrisa, los huequitos... Pienso en Baco, dios del vino y de la fiesta que en tiempos modernos puede ser cualquiera que se deje llevar por la propia fiesta sin importar dónde termine.

Caliche ha heredado muchos conocimientos de papá, sobre todo la artesanía de soldar, y el arte de la cerrajería, las lucecitas brillantes que despide el hierro cuando se funde de calor... igual que el cucho fue al Sena, una institución pública, donde perfeccionó lo aprendido en el taller de mi padre, junto a él y los ayudantes que tuvo papá: Ernesto, Garbanzo, Jaimito... y en el INEM, de donde salió graduado en la especialidad de metalistería... Soldar y farrear sin muchos problemas, eso hace mi hermano... (eso hace mi cucho...), flotando por la casa callado muchas veces... haciendo ruido muchas otras, siendo silencio y escándalo los fines de semana, entrando a casa ya casi el principio de la otra semana. Y nuestra madre, cada vez, prometiéndose no decirle nada más que suene a cantaleta; pero por quererlo tanto a veces no duerme preocupada pensando en la calentura del barrio y mi hermano farreando. 
Bullicio, farra, "y Carlos no ha entrado".

Tastaseos, bombardeos, balas entre los combos del barrio, "y Carlos no ha entrado".

Ya quisiera mamá que fueran ovejitas los tastaseos para contarlos buscando el sueño, "y Carlos no ha entrado".

La esperanza es que mi hermano se consiga una mujer que no farree como él.

$\infty \infty \infty$

Para abordar a mi familia como un problema sociológico es necesario hacer precisiones y diferenciar asuntos. Por ejemplo, el objeto de los estudios sociales sobre la familia. ¿Cuál es la tipología de familia analizada? En primer lugar, encontramos estudios sobre la familia consanguínea, un conjunto de miembros unidos por vínculos de parentesco, que comparten un tronco, un apellido; en segundo lugar, podemos leer estudios sobre la familia de residencia, también denominada hogar.

Esta familia de residencia se refiere específicamente a un grupo de personas que, mediante un vínculo (o ninguno) de parentesco, afinidad o amistad, comparten el espacio y organizan conjuntamente la supervivencia (Rico de Alonso, 1999). Para el caso de esta etnografía sobre mi familia, el camino es la primera opción: por allí veremos la familia como un conjunto de miembros unidos por vínculos de parentesco, sin dejar de lado las relaciones individuales y colectivas que establecen con los espacios que ocupan. Un enfoque sistémico que en palabras de Malagoli-Tegliatti (1983), citado por Cusinato (1994), considera la familia el sistema relacional primario en el proceso de individuación, crecimiento y cambio del individuo. Un crecimiento, considerado en el seno del proceso de individuación, crecimiento y cambio de todo el sistema familiar.

Para comprender las relaciones familiares, sin embargo, no se hace explícito cómo se entiende desde la teoría este concepto. En realidad, es difícil encontrar una definición, diversos autores como Cusinato (1992), Gimeno (1999), Satir (1978), Hernández (1998) y Sarmiento (1994) definen la relación como un proceso de interacción entre los miembros de la familia. Para ver esto principalmente veremos el espacio doméstico sin aislarlo de lo público, o fuera de casa: la violencia de la gran ciudad y los conflictos de todo tipo, políticos, económicos... de fuerza... de poder... se manifiestan en nuestro pequeño universo sociológico que no se inscribe solo en el interior de las casas y la violencia doméstica. 


\title{
14. iA a a mí, me me me echaron de la casa!
}

\author{
Sí, pero mientras tanto yo hago la guerra. Buenas tardes. \\ Alfredo Molano, Siguiendo el corte
}

El tío Miro terminó su bachillerato gracias a un subsidio que recibía del abuelo. Pero nunca obtuvo el título bachiller. Dado que el colegio en el que se matriculó pasó a hacer parte que la Universidad Autónoma, tuvo que validar primero de bachillerato. Cuando ya lo había cursado, como para demostrar su competencia, ya casi listo a terminar el último grado, y obtener su título... vuelven y le piden que lo valide de nuevo y ahí sí, iya no! A Miro le dio como piedra y más bien se quedó sin graduarse... Quería estudiar derecho o sociología, pero la verdad, y como él mismo lo dice, con eso de la validación le dañaron el caminado.

La historia que viene, la del tío Miro y su salida de la casa del papito, fue posible porque ni él mismo la censuró. Eso me alegró. Nunca me hubiese sentido capaz de preguntarle por las dificultades que se dieron un día en la casa donde creció, y las razones que tuvo para marcharse.

Miro Tales Cárdenas me pareció inquietante desde un día cuando en el balcón de la casa de los abuelos explicó su gusto por fumar, sencillamente porque era algo que parecía muy bacano, es decir vistoso, interesante, de película...: "fumar es muy bacano".

Bacano, vistoso, interesante, como de película es el tío Miro, que muchas veces aguanta el voltaje de la música de sus hijos... Desde mantener sintonizada Radioacktiva (la única de rock en Medellín) todo el día hasta en el carro, y escucharles sus ensayos, cargarles sus instrumentos, conectarles sus parlantes para cuando se presentan a sonar su música propia. Son músicos aficionados mis primos Andy y Dany; pero, además, ante todo precavidos. No esperan vivir de la música, así que 
no es lo único que hacen. Andy estudia publicidad, y Dany, tercer año derecho... ¡A lo mejor termine un día de fiscal!

Tocan rock duro, y el tío Miro como un cómplice lo disfruta, aunque preferiría que sus hijos tocaran algo caliente como la salsa: "!Hasta les compraría saxos y más percusión!".

Mi tío dice que los hijos le salieron músicos por el bisabuelo materno que cantaba en las iglesias. De pronto no le atribuye mucha importancia a que él mismo siempre haya querido aprender a tocar guitarra. El papito Fonso le dio una guitarra que apenas rasguñaba, y con la que Andy soñaba ser una estrella del rock cuando apenas era un niño. Entonces Miro le regaló una eléctrica, pero con la condición de que se pusiera más atento en el estudio. $\mathrm{Al}$ respecto, con los años Andy no deja de relajarse como Dani de esforzarse.

Con el abuelo Fonso, el tío Miro siempre tuvo una buena relación, tan abierta y sin trampas, como para contarle sin rodeos que le había sido aceptado su ingreso a las filas de la guerrilla urbana del M-19. Todo era resultado de las ideas que le habían metido sus profesores en torno a Marx y Lenin... Aunque al principio Miro comenzó a decir mentiras frente a las llamadas que recibía de sus camaradas, leyendo y leyendo mucho y saliendo por ahí, se decidió y el papito Fonso le dijo: “¿te estás embobando o qué?”.

Se le enojó, y el día en que mi tío pensaba irse para el monte, papito le dio una pela y no lo dejó salir ni siquiera al balcón. A los días asumió que el verdadero trabajo de campaña era salir de casa, ser útil a la familia: se metió a empacar aceite para carros, luego fue hasta el municipio de El Bagre a administrar un almacén de ropa, que era propiedad de un tío materno suyo...

- Le conseguí plata y me echó. Los envidiosos que no faltaban, le decían que yo ¡me la ganaba toda!

Hoy, después de todos los años de la vida, bien jubilado de la Electrificadora de Antioquia, veo al tío Miro al volante de una Trooper roja, apenas alcanzando los pedales, y con un libro de historia en el asiento el copiloto, la Europa de Hitler: "de pronto se lo roban a uno en una pesca milagrosa, de esas que hacen por esta carretera, y ahí está libro para distraerse".

Reímos... Mientras observo el paisaje, de camino a su casa, en el oriente de Antioquia, el tío me dice que si me agarra por ahí cualquier grupo de personas armadas, que no me las dé de sociólogo: "ya el discurso no importa, ni la forma ni el método, de pronto lo confunden, y ¡lo pegan!”. 
De la casa de mis abuelos ya se habían ido su hermano mayor Alberto, o sea mi papá, y la tía Hael. Ambos resolvieron casarse muy temprano, entonces las cabezas visibles venían siendo Melia y Miro. Con la tía Melia fue la pelea por la cual el tío Miro tuvo que irse de la casa de los abuelos, irse definitivamente, aunque la familia de su novia - luego esposa - viviera en frente... A veces hay que dar la vuelta al mundo para estar del otro lado de la calle, frasea la película My Blueberry Nights (Wong Kar-wai, 2007).

- Melia empezó a andar con un man que la visitaba, y entraba a la casa... como se dice, como Pedro por su casa. A mí eso no me gustaba. Pasaba por encima de mi amá como si nada, sin determinarla. Yo me quejaba y le decía lo de Melia a mi papá, pero nada. Un día no pude más, mi hermana y yo discutimos, iy le pegué! Yo mismo fui a donde mí apá, que trabajaba en un centro de bombeo de agua cercano a la casa: le conté lo sucedido, y a él le pareció que lo mejor era que me fuera de la casa.

Desde entonces, el tío Miro ha preferido el campo a la ciudad. Se fue a arrancar papa, y después adonde una tía paterna en el municipio de Bello: "cuando eso, el municipio de Bello todavía era un potrero", y esto hasta que un amigo del abuelo lo ayudó a colocarse en la Electrificadora. Se casó con su novia, Elda, y se fueron al suroccidente del departamento, a los municipios de Frontino y Santa Fe de Antioquia, y luego al oriente, Marinilla y otra vez Medellín... Retrospectivamente, el tío dice sentirse bien, pues tiene una familia. Le molestó mucho haberse alejado de sus padres y no ver crecer a sus hermanos menores... pero como el camino por donde vamos, todo quedó atrás... Adelante solo está lo que no ha llegado.

-Después de que murió Ed, supe que le gustaban las drogas y el gatilleo; nunca llegué al matrimonio de ninguno. Seguro me invitaron, pero no vine a ninguno. Lo más que hacía era llamar por teléfono y preguntar por la gente. Muy tarde me enteré de las andanzas de mi hermano $\mathrm{H}$, y que también Melia se había ido de casa. Pero mejor que todo ocurrió así. Si hubiese estado allí en esos momentos, en cada momento, no sé cómo hubiese reaccionado.

Sin duda que tomar distancia de la familia resultó benéfico para Miro y su esposa. Edificaron su hogar, como todos, con lo bueno que traían, evitando lo malo que sabían que tenían... Así, sus hijos y los de sus hermanos, retoñaron, crecieron, y hoy estamos aquí hablando de todo eso... y la gran pregunta que siempre le tenía, viéndolo siempre enfrente de la casa los abuelos, pasando por ratos a saludar, pero nunca a quedarse... se la pude por fin hacer: ¿ ¿por qué nunca pasabas a casa de los papitos?

—... A a a a mí, me me me echaron de la casa, entonces... ¿ para qué quedarme? 
De regreso a la autopista, mirando los alrededores... el tío me dice quién está de cada lado: "los paramilitares por allí, los guerrilleros del ELN por aquí, los de las FARC-EP por allá... los del Ejército por acá... Utilizan toda esa arboleda para esconderse, de por estos sitios salen a San Vicente, a Guatapé, a San Luis... Lo aconsejable por acá es no hablar mal de nadie, así que ipilas con lo que escribe!”.

$\infty \infty \infty$

La familia como objeto de debate y estudio cobró importancia en el fin del siglo $\mathrm{xx}$ dentro de ópticas que reconocieron recientemente su interrelación con una multiplicidad de procesos que la rescatan del mundo privado: Linton (1965), Gutiérrez de Pineda (1968), Beauchamp y otros (1977), Berger y Kellner (1983), Rico de Alonso (1986) y Henao (1995). La relación de la familia con otros fenómenos sociales que afectan sus formas convencionales de organización, como la ruptura y la recomposición conyugal, los hogares monoparentales, la reducción de la fecundidad y el impacto de la migración y la urbanización sobre el espacio habitacional, el desempleo, el empobrecimiento, etc. todo un continuo de violencias presentes día a día (Scheper-Hughes y Bourgois, 2004), cuyas interacciones se manifiestan por medio de la comunicación, permiten observar los conflictos, las reglas y las normas que regulan la homeostasis del sistema familiar, ya que el comportamiento de cualquier elemento del sistema lo altera en su totalidad (Macías, Paternina y Vargas, 2014). De este modo, la familia y estos fenómenos aparecen confundidos como causa y efecto, de allí la perspectiva dialéctica bajo la que se leen drásticas modificaciones en los roles y en las relaciones de poder entre hombres y mujeres, entre jóvenes, ancianos y adultos.

En 1965, Ralph Linton, uno de los primeros antropólogos culturales que observa la familia, llevó a cabo un estudio comparado entre sociedades primitivas y sociedades contemporáneas en torno las formas de organización de las relaciones sexuales y parentales, en cuanto núcleos de convergencia o de coincidencia de muchos pueblos sin contacto unos con otros a lo largo de la historia, con soluciones culturales de corte sistémico: el sistema familiar se encuentra compuesto por diferentes subsistemas, entre los que se destacan el subsistema individual, conyugal, parental y fraternal; pero tras dicha convergencia se oculta un problema que no fue una grave preocupación para Linton ni para algunos de los posteriores antropólogos que transitan los caminos abiertos por él; se trata del problema de una suerte de naturaleza humana que se adivina más allá de la cultura, tal vez como un 
foco de irradiación de la creatividad del hombre, pero también como un núcleo de selección entre las formas posibles ensayadas y de atracción convergentes hacia las que demostramos históricamente una mayor idoneidad para resolver nuestros problemas (Henao, 1995).

Esa naturaleza humana, así entrevista, quedará como flotando más allá de la cultura, en buena parte confundida con ella, sin desconocer que el ser humano es un animal cultural, que la cultura permite un método eficaz de adaptación a la naturaleza a través del lenguaje simbólico y de la técnica, cuyo primer escenario es la horda. Así, la diferencia entre naturaleza y cultura es la diferencia entre lo congénito y lo adquirido; entre genes y memes (rasgos genéticos y rasgos culturales); entre lo almacenado en el genoma, el órgano de la naturaleza y en el cerebro, el órgano de la cultura, de la moral. De tal forma, vemos que la cultura determina gran parte del proceso de individuación, crecimiento, cambio y socialización de las familias, por lo que resulta imprescindible recurrir a la sociología y la antropología para conocer la cultura de estos grupos y así comprender sus actuaciones, sus maneras de relacionarse y de enfrentarse a la vida.

Desde este parámetro, Hernán Henao (1995), uno de los antropólogos colombianos más interesados en la familia, la propone como un ángulo de mira, por cuanto es una de las instituciones sociales a las que se le ha fijado el papel socializador o endoculturador: la familia como espacio para la intersubjetividad y donde se funda toda relación ética, según propone el filósofo francés Onfray (2008). 



\title{
15. Eso para mí era como un sueño
}

\author{
- ¿Yel amor? \\ - Albergar un hermoso sueño y comportarse de la forma más \\ insensata posible. \\ Aloisa Kirschner, en Ocho escenas de Tokio, Osamu Dazai
}

- Estar ahí sentada al lado de un novio como dos horas mientras me visitaba me parecía algo muy aburridor. Yo prefería estar por ahí brincando con las amigas; pero la verdad es que mi mamá no nos dejaba tampoco, entonces no me animaba. Yo, de por sí, era muy tranquila para eso de los amores: si estaba con novio bien, si no, también.

—iQué tranquilidad! —le reprocha Rigo, el esposo de mi tía Rubi.

Y fue la tranquilidad como una característica personal la que originó esta historia pues, al parecer, Yonnatan, el hijo mayor de esta pareja, es igual de tranquilo con sus novias como lo fue mi tía Rubi en su noviazgo con Rigo, hace veinte años atrás...

Yonnatan es "malito" para el estudio. Por estos días en que perdió el año, antes de reiniciar el colegio, sus papás lo tienen trabajando en la construcción con un vecino del barrio. ¡Pa’ que sufra!

— iA ver si el esfuerzo lo aterriza y rinde más!

Apenas hace poco que llegó del trabajo/castigo y mientras se cambia para ir a jugar fútbol, habla por teléfono con su novia, quien al parecer esperaba verlo; pero Yonnatan ha decidido mejor irse a jugar. Su nena protesta; el primo le dice: “isi le sirve, voy mañana!".

Y la tía sonríe. Me cuenta que se preocupa más Rigo por las novias de Yonnatan, que el propio Yonnatan. ¡Bacano! ¡Qué se va a uno a amargar la vida desde ya por una mujer! Mejor ir a darle patadas a la pelota de fútbol. Aunque la pelota pateada por hombres... Lo femenino contra lo masculino... Tal vez es la preparación para 
un asunto relacional de géneros.... Yonnatan piensa que ya habrá tiempo para eso, si es que realmente llega a haber algo más importante que el barrio, los amigos, el juego... Así pensaba mi tía, doña tranquilidad, para quien tener novio era como jugar... y, sin embargo, ¡se casó!

-Yo tenía 23 años cuando eso, y mi papá me decía que estaba muy joven para casarme, que debería tener otros novios.

En realidad, tanta generosidad era porque a los abuelos no les gustaba mucho Rigo como compañero eterno para mi tía.

- Gélica era diciéndome que para qué me iba a casar con él ¡¿cómo era de celoso?! ¡Para mantenerme encerrada!

Y cuenta el mismo Rigo que hasta de entrometida llamó a la abuela Gélica por cuenta de ese comentario. Entonces empezó a jodérsele la relación hasta con mi abuelo Fonso.

—Ocho días antes del matrimonio — recuerda Rubi- Osorio, Willi y Raúl le hicieron la despedida de soltero. Bebieron desde el día anterior abajo en la acera. Cuando eso, los novios no nos podían visitar si mi papá estaba trabajando de noche. Era supuestamente una orden de mi papá; pero él ahora dice que no, que eran cosas de mamá.

Y, todavía hoy, Rigo se queja porque la imposición era solo para él, y para ninguno de los novios de las otras muchachas.

-Esa vez, al Rigo le da por subir a la casa con una cerveza y en ese momento llega mi papá y se le queja: "usted que va a ser parte de esta familia y dando ese ejemplo. ¡No sea sinvergüenza!”. Y que se fueron a las palabras y después a las manos...

— ¡Tíreme, don Fonso, tíreme!, que usted no me conoce sino la sonrisa.

Según Rubi, el abuelo casi ahorca a su novio aquella noche. Él, en cambio, no dice nada respecto a esta versión; mejor destaca con ironía que, hoy por hoy, ese par de viejos, mis abuelos, lo quieren mucho. Y la verdad, parece cierto. Después de todo, cualquier padre desea el bienestar para sus hijos. Y no es por nada, pero Rigo tiene viviendo muy bien a su familia. Han enfrentado dificultades económicas, pero ahí van.

El noviazgo a lo mejor nunca fue nada en serio para la tía, hasta cuando su novio tuvo que irse al cuartel...

-Ahí sí lo valoré, cuando ya no estaba! — dice Rubi.

Antes, cuando eran novios y rompían, la tía conseguía otro chico... y después volvían. 
-Fíjese usted. A mi mamá nunca le han gustado las personas negras; pero me dejaba charlar con uno, seguramente por lo celoso y lo problemático que le parecía Rigo... Una vez yo le compré una camisa de regalo, y en un baile, como yo casi no bailaba con él, de la rabia, se fue hasta la otra esquina y rasgó la camisa.

El otrora novio, ahora esposo, sonríe en silencio, un poco apenado, pero comprensible. Enamorado se hacen cosas ridículas.

-Otro día terminé saliendo con un vecino. Yo tenía 16 años; él, 27. Resulta que salí con mi hermana Melia para el centro de la ciudad y ella convidó a ese muchacho. Ella se fue comprar un regalo y nos dejó a él y a mí en una heladería, esperándola. Ahí me dijo que yo le gustaba. Por entonces, Rigo era muy amigo de la familia de los Madrigales... Una familia de vecinos que hacen música, y como Rigo les colaboraba cuando tocaban... En un baile que hubo con ellos, ahí estaba Rigo todo celoso, parado en la puerta, como para no dejarme bailar. Entonces yo le dije al muchacho este que mejor me iba para evitar problemas; sin embargo, me quedé con él un ratico en la puerta de mi casa antes de entrar. Al otro día me llamó el muchacho ese como a las 10 de la mañana. Que saliera, que me que me asomara a verlo...

${ }_{-} i$ Ve lo que me hizo el monito ese, el novio tuyo!

Pacheco, otro vecino, le había prestado un cuchillo a Rigo, con lo que se le fue encima al muchacho amigo de mi tía...

-Aunque creo que fue con una piedra que Rigo lo lastimó, justo debajo del ojo derecho.

—Lo más verraco es que él todavía tiene esa cicatriz... — dice Rigo.

- iEsa fue la única vez que Rigo peleó por mí!

-Y con su hermanito $\mathrm{H}$, ¿qué? -interviene de nuevo su esposo.

Esa pelea con mi tío $\mathrm{H}$, bien podría ser otro capítulo de este álbum familiar, pero mejor resumirla: eran los años ochenta en El Pedregal... Como en un poema de Helí Ramírez.

Una pelada muy marihuanera le dijo a $\mathrm{H}$ : "ese monito novio de tu hermana tiene otra vieja con dos pelados por allá en Niquía". Y mi tío, todo solidario, a la defensa siempre de los intereses de la familia, se fue a buscar al Rigo; pero mi tío terminó corriéndole a Rigo...

Lo persiguió hasta el barrio de La Maruchenga acompañado incluso de la Policía. Querían sacar de por allí a mi tío $\mathrm{H}$ y, de paso, a tanto lumpen.

¿Qué vaina con mi tío!

Luz, su esposa, me contó que por aquellos días sorprendió a mi tío borracho, llorando, como enloquecido, diciendo que nadie lo quería y que toda su familia lo 
rechazaba. Pero Rigo sí tenía una vieja por allá en Niquía; no era su amante, sino una hermana suya, y los pelados, sus sobrinos.

-Nos casamos, y por el problema ese de mi papá con Rigo, mi mamá — pobrecita- era diciéndonos que no nos fuéramos a ir por ahí de rebeldes, que mi papá nos tenía preparada una reunioncita en la casa, que nos quedáramos.

- Ya casados - dice Rigo - un tiempo estuvimos viviendo por los lados del barrio 12 Octubre, por la cancha de la Ediluz. Luego nos conseguimos un apartamento en Niquía, al norte. Aunque debimos regresar al barrio El Pedregal, primero por dificultades del embarazo de Yonnatan; después porque nos cogieron la casa a bala unos ladrones que se nos querían meter... Nos fuimos por el miedo de Rubiela, y nos regresamos porque nos aburrimos... Y es que El Pedregal, Florencia y Santander, eran barrios más calientes que Niquía. Ahora regresamos de nuevo y muy bien... Aunque resulta un poco maluco bajar a Medellín: atracan mucho dentro de los microbuses. Entonces camino hasta el metro, y de una llego hasta la fábrica.

Rigoberto Osorio estuvo trabajando en Haceb, una empresa de electrodomésticos por lo menos unos quince años, hasta que la empresa comenzó una serie de cambios típicos de la globalización del capital... Que lo dejaron por fuera... como a muchos otros. Y a punta de préstamos ha levantado su casa, la ha pintado y la ha amoblado... Ya tiene una familia grande que incluye nietos. Cuando me decidí visitarlos para conseguir esta historia, todavía vivían en Niquía. Han regresado al barrio El Pedregal. Sigue trabajando y amando a su familia. Sigue endeudándose. Y Yonnatan, después de ganar los años restantes del colegio, también se hizo policía, como otros primos.

Recuerdo mucho a Rigo con una cámara de video que consiguió... Tal vez sea con sus ahorros o con lo que le dejó la empresa... Siempre grabando todos los encuentros de la familia. Pienso que esta historia guarda el mismo sentido que las imágenes que ha logrado de nuestros encuentros. Recolectamos hechos pasajeros para no olvidar lo que hemos sido en medio de esta búsqueda por seguir siendo. 


\title{
16. Cuando uno se va a manejar mal, no hay quién lo ataje
}

\author{
Benedicto: ¿cuál es la ofensa, dulce Beatriz? \\ Beatriz: me habéis detenido en un feliz momento, estaba a \\ punto de protestar que os amo. \\ William Shakespeare, Mucho ruido y pocas nueces
}

Mi tía Melia y su novio Alejandro siempre conversaron, pues él y mi papá fueron compañeros de colegio. Se dejaban por tiempos, entonces ella conseguía otros novios, y él también conseguía otras novias... Pero Alejo siempre la mantuvo como arrocito en bajo, siempre molestando, "y eso que era muy perro; pero ¡nos casamos!”. A él lo querían mucho en la casa de los abuelos. Fonso decía que era muy verraco, porque el día que pidió la arrimada a la casa para visitar a Rome, fue y sudaba que daba miedo, y lo hizo... Pero la tía interrumpe su relato y me dice:

- ¿Por qué me preguntas eso?

- ¿Le choca o qué tía? - contesto.

Con sus palabras entrecortadas, aguadas por lágrimas... Melia se pone triste y yo espero a que se tranquilice. Le acerco un poco de agua... Espero... Y recuerdo mientras tanto... a Alejo al volante de su camión, un HI:

—Un día Alejandro volvió en su camión, y me dijo "listo, negra, yo sé que esa es la única forma...”.

Cuando él la iba a visitar aprovechaban las salidas de Melia a la "dentistería" para averiguar dónde los casaban. Terminaron en la Iglesia del Perpetuo Socorro. Hasta el último momento mintieron:

—Que es que vivíamos juntos y nos queríamos mucho... Y yo la verdad sé que él me quería más a mí, que yo a él; pero yo se lo había dicho: que yo no quería a nadie, fue entonces cuando le puse mi condición. 
Hicieron el cursillo, consiguieron las argollas. En fin... la fecha señalada fue el 4 de agosto. Él insistía que quería verla de un vestido bien lindo.

— ¿Cómo?, ahí sí me pillaban — dijo Melia.

Ocho días antes ella había sido madrina de una niña que bautizaron por allá abajo en "El Baratón”, y había estrenado un vestido apenas para la ocasión.

-Ese día solo me lo puse un momentico, entonces decidí casarme con él. La mentira ya estaba montada: me creyeron otra vez el cuento de la dentistería y que luego visitaría a una amiga... Pero resulta que Álvaro, un primo de Alejandro, no pudo llegar con mi partida de bautismo, que era del municipio de Heliconia. No pudimos casarnos ese día. Mi amá casi nos pilla: que qué era esa llamadera de Alejandro y bueno... con el cura se había arreglado nuevamente una misa para el día siguiente a las 12 . Yo le dije a Alejo que ya le tocaba a él organizarlo todo, que yo ya no podía con otra mentira. Él la planeó y fue y le dijo a mí apá: "que como él al otro día salía temprano para Barranquilla y que solo a las 12 le iban a pagar un cheque, que si me dejaba salir a reclamarlo y mi apá no puso problema.... Me demoré lo que duró la misa. Yo cogí ahí mismo pa' mi casa, apenas si hubo tiempo pa' una gaseosa. Los padrinos fueron Martha Inés, la amiga a la que supuestamente iría a visitar, y el doctor Sanín, amigo de Alejo. Él mismo nos prestó un carrito cuando después de casados volvimos a la ciudad.

-Y entonces ¿cómo quedaron las cosas?, ¿se casaron, y?

-Por la noche Alejandro apareció con una borrachera, que me cogía a picos y yo que no: "Alejo, mira, que nos van a pillar". Y mi apá le pregunta que qué hubo del viaje: "no, don Fonso, vea la hora que me entregaron el camión”, dijo el conchudo.

Alejo volvió unas cuatro veces más, normalmente, como cualquier visita de novios y no hubo nada, ni cuando estaba él en la cama por unos hongos que le dieron en los pies: yo lo visitaba y le compraba la droga; pero él en la cama yo en una silla... Y mi mamá que le metió una vaciada a la tía de él, allá donde él se quedaba a amanecer... Quién sabe qué se imaginaba

En una de esas veces, le trajo un vestido desde la ciudad de Barranquilla y unas chanclas. La mamita Gélica llamó a Fonso, y Melia escuchó lo que se decía:

-Que ahí estábamos, pero que todo era normal. Yo me estaba poniendo troza...

- ¿Estabas en embarazo o qué tía?

— ¡No te digo que nada de nada, pues! Y mi amá dándonos vueltas como con ganas de preguntar quién sabe qué. Incluso dejé solo a Alejandro a ver si ella arri- 
maba y preguntaba algo y nada vos. Al otro día, mi apá me sale con la cantaleta de que cuidado como hacía las cosas... Ese día era definitivo, el definitivo...

Alejandro decía que ya no se aguantaba sin Melia. Se vistió y cuando mi papito Fonso la vio con el vestido y las chanclas explotó: "Que si estaba en embarazo, que si me iba a casar o qué había hecho que últimamente estaba muy rara".

-Yo le dije: "Sabe qué, apá... Me casé con Alejandro". Y le expliqué por qué lo había hecho... Huy, es que todavía me acuerdo y me da tanta rabia. Mi amá decía que él era poco hombre y los muchachos llorando, Raúl, Hétor Mario, Willi... Yo esperaba a Alejo desde las cuatro. Esa era la quinta vez que nos veíamos después del matrimonio y cuando él llegó le conté que mis papás ya sabían. Alejo se metió una macheta atrás por si mi apá le tiraba; pero cuando entró, él le preguntó que qué era lo que habíamos hecho y Alejo le decía "tranquilo, don Fonso, siéntese y hablamos", y mi amá rebotada. Y los muchachos sentados. Mi apá les dijo que se acercaran.

_- "Déjalo hablar...", le decía su papito a mi amá... Entonces ella se fue para las escalas reclamándole el que no me hubiera dado ni siquiera un vestido... que disque las argollas fueron un par de latas ahí... decía ella.

-Mijo, usted ya es como de la familia, decía mi apá y mi amá encima...

- Quédese, insistía mi apá, ¿ pa’ donde se la va a llevar?

-No, don Fonso, doña Gélica no quiere, yo me llevo a la negra en mi camión.

Y Alejo le da por decirle a mi amá que me diera la bendición...

— Que se las dé el que los casó — decía ella.

-Negra, recoja sus cosas — puntualizó Alejo. Hasta matas me llevé. Y los muchachos llorando.

En el barrio Villa Hermosa nos guardaron las cosas y yo me iba con Alejandro a viajar, pagábamos hotel. Como a los dos meses llamé a su papá. Él y yo siempre nos la llevamos muy bien, nos vinimos a pelear fue en estos días. Bueno... él me dijo: "Loca, ¿dónde estás...? Pasen por acá por el bombeo donde estoy trabajando".

Por esos días, mi papá era operador de aguas en municipios como Abejorral y Guarne... Cuando se vieron, le pidió a Melia que viera al papito Fonso, que él estaba muy mal, sufriendo del corazón.

-Uno y otro después de verme le dijeron a mi amá que yo no estaba en embarazo, aunque para todos por aquí, sí. Aún hay quienes creen que Juan Camilo nació antes de casarme, pero él nació a los dos años de casados.

-Yo me acuerdo del apartamentico en El Pedregal que ustedes tenían por ahí donde estaban viviendo antes de venirse para acá.

-Sí, ahí nació Juan Camilo. 
Esta es la historia del matrimonio de mi tía Melia con Alejo. Al final, pienso que luego de tanto tiempo Alejandro sigue fiel a lo que implica una aventura, como casarse al escondido, como viajar sin tener asegurado pa'l regreso. Ahora que soy un adulto y tengo pase de conducción, me encantaría volver a manejar su camión... Desde este balcón, el mejor lugar de la casa de mis abuelos, allí donde me cogí estos detalles y otros que me reservo por puro respeto a mi tía y a mi mamita Gélica, me parece estar viendo el HI, a mis primos y al tío Ed correteando en el planchón. Hace 23 años se casó la tía, desde eso y quizás más, Alejo tiene ese camión, Paula ya tiene 15 años y mi primo Juan Camilo... quien hizo de patrullero de la Policía, en el teatro de la guerra, muere luego bajo un bombardeo de las FARC-EP al hotel donde dormía.

$\infty \infty \infty$

Ver cada pequeño gran drama de la familia consanguínea nos permite hacer referencia a todas las formas posibles de familia. Desde la extensa, concebida como pilar del ethos tradicional, hasta la díada madre-hijo(a), a la cual se le ha concedido legitimidad. Así lo propone Linton (1965, p. 158), citado por Hernán Henao:

Todas las sociedades reconocen la existencia de ciertas unidades cooperativas compactas, organizadas internamente, intermedias entre el individuo y la sociedad a la que pertenece. Teóricamente, toda persona pertenece a una u otra de estas unidades, por razón de relaciones biológicas establecidas por el ayuntamiento sexual o la ascendencia común. De hecho, tal asignación puede también apoyarse sobre la base de sustitutos reconocidos, como la paternidad supuesta y la adopción. Estas unidades tienen siempre funciones específicas en relación tanto con sus miembros como con el total de la sociedad. (1995, p. 2)

En los estudios de Virginia Gutiérrez de Pineda (1975) encontramos que la característica básica de este complejo agrupamiento social es la forma de unión, la cual es de facto o de unión libre, y la integración familiar, cuya etiología se encuentra en la continua movilidad de los hombres que desde jóvenes van de un lugar a otro en busca de mejores condiciones de vida, o actividades remuneradas, resulta bastante débil. Lo que podemos ver, además, es que hay una serie de funciones en la familia que vienen de su doble condición biológica y cultural, como son la reproducción, la producción económica, el cuidado de los ancianos, la protección de sus 
miembros contra los extraños y la educación y cuidado de los hijos. Es la condición de socialización o endoculturación que Onfray (2008) propone a la familia, en tanto es el lugar del vínculo entre la instancia doble del individuo (en) la sociedad.

Y aquí, aparece el punto en torno al que el profesor Hernán Henao propone sus interrogantes apropósito de Medellín y la crisis que vive esta ciudad ( y la familia) desde los años setenta, a lomo de caballo entre los valores tradicionales de la sociedad rural decimonónica y los nuevos valores que propone la urbe, y es que en la instancia de la socialización se suponen conscientes o, por lo menos, presentes las actividades propias de la trasmisión de patrones de comportamiento entre hombres y mujeres, y grupos humanos de todo orden y condición:

Las reflexiones sobre Medellín vienen de todos lados, por la crisis que ha vivido su población en los últimos años del $\mathrm{Sxx}$, se ha llegado al punto de afirmar que la ciudad esta sobrediagnosticada, y ahora lo que se ha debido hacer es adelantar acciones que permitan superar las situaciones de tensión social, conflicto, delincuencia, narcotráfico, terrorismo, en que se han visto envueltos todos los pobladores del Valle de Aburrá. (Henao, 1995, p. 3)

En contextos como este, las uniones son el resultado de transitorias atracciones físicas. Pasadas estas temporadas, o las tensiones y conflictos que reseña Hernán Henao, las mujeres vuelven a quedar solas y las uniones se deshacen; sin embargo, la desintegración hogareña no limita a las mujeres en sus tareas biológicas. 



\title{
17. Metáfora para las niñas
}

\author{
¡Me protegi el cuello con un cinturón de cuero para que no me \\ mordiera, mira! \\ Kenzaburo Oé, La presa
}

Las niñas de mi tía Ilsa son como una especie de medidor del paso del tiempo. Va el tiempo con sus ritmos, las niñas creciendo tras de sus risas locas y a veces sin control, y sobre la piel de Ilsa albergada la belleza de una mujer que siempre ha sido bella: la menor de la casa de los abuelos se escapó un día tras el bandido - ladrón de su corazón- Osorio, su novio durante siete años, su marido por otros siete. No había cumplido Ilsa los veintidós cuando se fugó de casa buscando el amor, y como no se casó, por lo menos al día siguiente, el papito Fonso no fue al matrimonio que se realizó meses después... y la mamita Gélica dice haber pasado por encima de él para poder verla casar.

-Yo me fui de la casa en enero - dice Ilsa - y en octubre nació Cristina. Con Cristina, Osorio parecía un niño, la defendía al punto de llevarme la contraria. A Cristina nunca le ha gustado comer. Siempre ha sido así de flaca y pudo serlo aún más si yo no le embutiera la comida casi a las malas. Ella resabiada, y Osorio apoyándola para que no recibiera nada...

Y en medio de los años que le van dejando sus muchachitas cada vez menos muchachitas y muchos recuerdos como a todos, Ilsa se sostiene no solo siendo bella sino aguafiestas, como ella misma se califica. Dice Ilsa que de no ser porque trabaja, nunca saldría de su casa... Así siempre fue con Osorio, quien solitario se arrojaba a la calle en busca de ambiente sin su dama, porque ella prefería mejor quedarse en casa como lo sigue haciendo hoy, con sus hijas.

El Osorio, según cuentan, era el dueño de la noche, y encantaba con sus historias de cómo capturaba a las estrellas evadidas del espectáculo al que les tocaba 
pertenecer... y de novio de Ilsa, a su alrededor, se sentaban los muchachos de la casa, Ed, Hétor, Raúl y Willi, embelesados todos por esas historias de fuga en medio de lluvias celestes que amenazaban al Osorio en el cumplimiento de su misión... Katherine tenía veintidós meses cuando el destino alcanzó al Osorio con sus gotas encendidas y ardientes; sin embargo, Kate se ha hecho en la memoria la más fiel imagen de su padre...

—Cada disco de salsa que oía le permitía reconocer la música del papá —recuerda Ilsa-, y como él, Kate se puso fastidiosa e igual de voluble... Un día decidía no hablarle a Ed, por ejemplo, solo porque así se le antojaba. Igual que hacía el papá. Cualquier día, Osorio decidía no saludar a nadie, solo porque no tenía ganas de hacerlo, entonces ignoraba a todo el mundo...(O ignoraba el mundo lo que Osorio tenía en la cabeza. Su misión)

Para Ilsa, Cristina está en la edad de entender algunas cosas, como las circunstancias en las que murió su papá, ¡Kate, no!

- Si hasta un día se rebotó en llantos y reclamos contra mí, por supuestamente, hacer permitido que se muriera Osorio.

Cristina pasa buen tiempo frente al espejo arreglándose luego de cada baño. Y peina su cabello largo, y mira sus ojos puros y se perfuma un poco y sonríe soñando con ser modelo o locutora de radio. Tiene once años la Cris del espejo y ya dice que nunca se casará ni tendrá hijos. Seguro se equivoca. Tendrá dos criaturas... Y Katherine haciéndole mala cara al desayuno solo sabe burlarse de su hermana y de su postura de señorita demasiado preocupada por cosas hoy tal vez vanas... pero que cuando crezca... seguro también adoptará.

Viendo a las chinas y entendiendo la preocupación de Ilsa frente a las muchas preguntas que seguro un día Kate hará, pienso en la huida de las almas hacía otro mundo y en la explicación que siempre hay que dar. Los actos de cada ser humano, perece, debieran estar siempre justificados... ¿Para qué capturar estrellas? ¿Lluvia de fuego? ¿Goteras ardientes? ¿Quién era papá?...

Papá era... Papá...

Así empezaría yo un cuento para Cristina y Katherine: las estrellas eran... las estrellas aunque fueran cangrejos disfrazados de estrellas que se querían robar la luna, y papá estaba allí para no permitirlo... Mientras, mamá se quedaba en casa a proteger un par de florecillas nacidas en el jardín de las caricias que Osorio depositaba en su piel al regreso de cada cacería, cada noche... 


\title{
18. Edison de Jesús Fernández
}

\author{
¿Vienes de trabajar? \\ Si, ¿por qué? \\ ¿Ese es el ejemplo que le das a tu hermano mayor? iQué \\ vergüenza! Tu hermano jamás ha trabajado, siempre ha hecho \\ lo que ha querido. Eres un degenerado. \\ Pier Paolo Pasolini, Accattone
}

Esta iba a ser la historia del tío Gildardo; pero también será sobre un hijo suyo y por cuya existencia, al descubrirla tan tarde, me sorprendí. Un primo que nunca conocí...

Yo sí sabía que mi tío Gildardo alguna vez estuvo casado con una mujer de nombre Dolores, que dizque se había casado prendidito - casi borracho-, lo cual fue un escándalo en El Pedregal; que de esa vuelta quedaban dos peladas todas linditas ellas a las que solo se les veía en la familia una o dos veces al año. Que separado ya algunos años después, se fue pa’ Venezuela a trabajar. ¡Ah!, y tengo muy presente, además, que buena parte de la vida ha sido mesero, y que es uno de los hombres que más quiere a mi mamá.

-Tío, vine para que me contés un chisme.

-Qué será mijo...

- ¿Cómo así que vos tuviste un hijo?

Y el tío Gildardo, sin dudarlo, dice que sí. Y antes que la respuesta, preferiría más bien saber qué pensó "Gilda" frente a esa pregunta... Lo que al principio me pareció una evasiva, fue ver al tío salir para su habitación dejándome ahí solo, pero regresó pronto con un par de fotos suyas. Primero, una donde Gildardo no parece que fuera él: acompañado de Edison y Adriana, dos de los tres hijos que tuvo con Dolores. En esa foto, Gildardo posa con todas las pretensiones de ser eterno: él con su cabello largo. La otra es una foto de una niña morenita, de cuerpito entero, que apenas 
comenzaba a caminar: su hija Mary Luz. Ambos retratos, copias muy regulares de las fotografías originales, se mostraban en exceso contrastadas al blancos y negros estallados-detentores del tiempo, pretensión de toda fotografía, retratos de sensaciones ya perdidas (de vista) u olvidadas (de memoria)...

En la sala de su casa, con la mirada lanzada a la calle por el ventanal grande de la sala, sentado en el mueble, de camiseta blanca por fuera, pantalón y chanclas, y con las medias puestas, mi tío Gilda se encamina a recordar:

- Lo mataron cuando tenía dieciocho o diecinueve años.

-Y eso ¿por qué, tío?

- Porque era malo y mantenía con esos muchachos malos de El Pedregal.

-Y ¿cómo era ser malo en esos días?

-Un ladrón... un marihuanero ahí.

Que en un tiempo no lo dejaban ni arrimar a la casa siquiera. El Edison le robaba hasta a los tíos... Y la mamá Dolores, que había sido una alcahueta de toda la vida, según cuenta el tío, lo dejaba entrar por el solar cuando el abuelito, don Pedro, y los tíos estuvieran durmiendo... Se la pasó callejeando y entrando por el patio hasta el día en que perdió...

- Por ahí más arriba de la escuela especial, por los lados de la cañada, estaban en un baile él, unos amigos... y de pronto lo llamaron unas muchachas. Él como que salió a conversar con ellas y fue en ese momento cuando lo mataron. Era de madrugada, y a mí me llamaron como a las siete... Me avisaron apenas a esa hora que lo habían matado... Eso fue como en el 85, a los diítas de muerta mi amá...

Cómo era Edison es, quizás, la incógnita del momento, por lo menos para mí. Y me sorprendía sobremanera, porque no creí posible siquiera pensar un tipo así en la familia de mamá. Aunque es comprensible, después de todo, la ciudad en sus ansias de crecer... los barrios populares... el rebusque... la esquina oscura, un tango y un café... Todos los Fernández vinieron a la ciudad ya creciditos, mi mamá era la niña, entonces sería la siguiente generación la encargada de demoler las aceras... padecerlas... El tío era un tipo joven para cuando Edison, callejeando, también lo era... Y me atreví entonces a preguntarle a "Gilda”, alabándolo de paso un poco, que si acaso su hijo no se habría parecido a él. Y muy seguro, rápido y confiado "Gilda" contesta decididamente que sí.

- ¡Yo tenía el pelo largo!

Lo confesó en cuanto pasó a contarme algo de Miriam Lotero, la mujer con quien vive como desde 1984 (y con quien tiene una niña bonita, Karina). Asombrado por lo del cabello largo, le pregunto que si es que fue roquero o algo así, camaján 
o pilluelo, y que si había fumado marihuana alguna vez... Y él a todo diciendo de una que no. NO...

NO... NO...

La pinta del tío cuando era joven era una de mucho estilo: patilla larga un toque, y en efecto de cabello largo pero bien cortadito... Las fotos por la tradicional calle Junín, en el centro de la ciudad, lo muestran usando camisas de colores en estampados bien sollados, de mangas largas, correas en cuero gruesas, gruesas como las chapas; chaquetas elegantes y un porte de bacán... hasta creo que se ponía sombreros... (Pero no veo pruebas).

- Yo vestía bien. Usaba un buen reloj, mis anillos... Me gustaba vestir bien... a lo mejor será por eso que...

-Será... que qué...

-Que ahora no me va tan bien...

-Pensás que fuiste vanidoso o qué.

- ¡NO!

Gildardo de Jesús Fernández Quiroz se casó el 25 de septiembre de 1965, recién cumplido los veintiún y Dolores apenas con diecinueve. Sin embargo, la cosa no andaba bien y pa'l año 1971 ya estaban separados. Vivían con los suegros y el tío con ganas de casa pa' ellos solos... Y, en efecto, de puro amor un día la consiguió; pero Dolores dizque prefería quedarse con sus papás. "Gilda" no aguantó y se regresó para donde los suyos: papito Gabriel y mamita Laura. Y, por si fuera poco, una orden de la inspección de El Pedregal le impedía volver a la casa (donde los padres de Dolores que eran donde vivían). Solo hasta cuando las muchachas estuvieron grandes pudo estar junto a ellas. Antes, según palabras suyas, la Dolores les decía a ellas que no tenían papá...

A pesar de ello, "Gilda" entregó ante el altar a sus dos hijas cuando a bien tuvieron casarse. Fue leal a su condición de padre, aunque desde el exilio... Y regocijado en el momento del recuerdo, deja ver el tío muestras de que en su momento le rogó a Dolores para que se fueran juntos: la familia. Y ella como que nada de nada. Estaba decidida a quedarse en casa con sus padres (salvo un par de veces en que Edison prometió cambiar y se fueron los cuatro: Dolores, Edison y las muchachas, a una casa solo para ellos: la familia. Pero Edison volvía y la cagaba y de nuevo adonde don Pedro). Eso de rogar por amor es algo que el tío no confiesa propiamente; pero seguro seguía enamorado. Lo casual de todo esto es que era la misma Miriam la que le llevaba razones a la Dolores de parte del Gildardo... y regresaba la Miriam que cuando señorita era una morena delgadita y bien bonita, diciéndole al tío que mejor se buscara otra 
mujer... Que Dolores no paraba bola, y qué casualidad que la otra mujer resultaría siendo ella misma... Qué casualidad... Vaya, vaya... El tío Gildardo y su hija Ana Karina sonríen cuando digo que a lo mejor Miriam tenía sus intenciones cuando daba la razón esa:

—No, negro, mejor búsquese otra mujer que sí lo quiera... Y resultó con dos: Miriam y otra pinta: Ana Karina (la niña bonita).

Lo del Edison, Dolores y Miriam; las peleas del tío cuando borracho por la avenida principal del barrio... Los abuelos y esa casa de dos patios... Puras sensaciones de olores que vuelven con solo pensar y decir un nombre: El Pedregal (un pedregal fue tu amor, cantaba Justo Bentancurt...).

-El Pedregal es mucho mucho mejor de noche.

- Me lo encontraba por ahí con sus amigos y de una me salía al paso y me pedía plata: "Cucho, cucho... — me decía cucho-". Una vez me iban a atracar. Ya me había quitado el reloj y una plata. Como a eso de la 1:30 de la mañana me cogieron unos manes ahí junto a "El Palmar". De pronto apareció el niño y les fue diciendo a los que me agarraron: "Hey, hey, pilas. Pilas, pues, que ese es mi cucho. Me le devuelven todo ya”.

-Y un pillo en esos días, ¿cómo se movía? ¿Tenía su moto o qué? - pregunto.

—No. El niño nunca tuvo de eso, como que andaba era con un amigo que sí tenía.

— ¿Verdad que estuvo en silla de ruedas por los días de velorio de la abuela Laura?

- Nooooo, eso es falso. A él... el día que le dieron, le dieron y se murió.

Según cuentan, un tiempo se estuvo en la ciudad de Cali y por allá con otra gente atracó almacenes Ley y quién sabe cuántos lugares más. Fue un tipo de golpes grandes y bajos que también recibió sus palmadas en la cara y en la nalga, aunque en vano quizás. Un día le robó un billete a papito Gabriel, era la segunda vez... El papito le había puesto la plata como cascarita y el pelao, en efecto, se resbaló: en tanto el viejo se pilló la ausencia del dinero, correa en mano se le fue encima... Lo echó para donde Dolores.

Tenía que pasar la avenida principal del barrio, luego la calle del pecao, y más allá por el bulevar donde todavía hoy se pasan la vida fumando marihuana. Esta calle lo transformó, anduvo en esta morada de pillos y vagos... Pasó por estos lugares y por encima no sé de quién más.... El pobre Edison llevó su pela... ¿Cómo imaginar a don Gabriel Fernández pegándole a un nieto suyo? Tampoco imagino al primo 
Edison... Por aquellos días, copiloto a lo mejor de una moto 100 roja o amarilla, dándose unos roces por el barrio, mostrándose...

Y ¿si no hubiera muerto...? Seguro seguiría diciéndole a mi tío "cucho”. Y como sé que el primo no habría dejado de ser el primo, así como mi tío $\mathrm{H}$ que no ha dejado de ser $\mathrm{H}$, el mismo Edison, como un personaje de un poema de Helí Ramírez seguiría cogiéndole el paso a la angustia que impele a la vida...

Con unos 33 o 34 años, según cálculos improvisados... tal vez estaría fumando yerba conmigo mientras me relata sus andanzas para este libro.

Pero de los recuerdos que quedan de verdad en mi cabeza, tengo al tío Gildardo levantándose tarde, en su bata de baño gris, cepillándose los dientes en el patio de atrás... Su habitación era la habitación de atrás... Para muchos eso de un divorcio o una separación sería un fracaso, yo pienso que es como un nuevo chance, opción de nuevas cosas... De pronto me sorprendo al ver cómo al final de esta charla Gildardo telefonea a Dolores, su exmujer:

— ¡Hola, querida! ¿Cómo estás?

$-\ldots$

- Oís, es que un sobrino mío que estudió sociología o algo así está haciendo una reconstrucción de las historias de la familia...

—¿Hace cuánto fue que nos mataron al niño?

$-\ldots$

- ¿Y vos no tenés una foto de él por ahí?

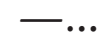

$\infty \infty \infty$

En plena investigación, truncada por la violencia política, el profesor Hernán Henao halla un documento de la Corporación Región, donde se señala que las causas de la violencia "de mil cabezas" que cunde en Medellín se resumen (para los años noventa) así:

La crisis de la institucionalidad política y el Estado. La ausencia de una ética social. Un ambiente social de tolerancia con el delito y la corrupción. La impunidad generalizada como consecuencia de la ineficiencia de la administración de justicia. La corrupción de los organismos de seguridad del Estado. La situación socioeconómica. La influencia del narcotráfico. La crisis de los modelos culturales tradicionales y ausencia de una cultura urbana sólida. 
Este último enunciado es el que anima las inquietudes del profesor Henao cuando trata de comprender al monstruo en que la ciudad se convirtió, al mismo tiempo que plantea el ánimo descriptivo de esta etnografía experimental: ¿cómo vivió mi familia ese aumento de la migración a la ciudad de Medellín de trescientos mil habitantes en 1951 a casi dos millones en los años noventa?

En un periodo de 30 años - dice el profesor - no están en capacidad de asimilar los cambios culturales que se producen en las generaciones nuevas, desarraigadas en su propio entorno familiar y vecinal, pero además ausentes de viviendas pueblerinas campesinas que les hubiesen permitido configurar su personalidad social por el camino de la comparación de modos de vida. (Henao, 1995, p. 9)

Recuperar valores perdidos frente a construir nuevos valores pareciera ser la primera tarea en la ciudad del fin de siglo. Volver a dilucidar el trasfondo de la sociedad rural, decimonónica, que permitió elaborar el mito de la antioqueñidad: esa es la realidad de mi familia, resultante de medio siglo de grandes transformaciones, el hecho grueso que se pone sobre este tapete etnográfico. Veamos, por ejemplo, cómo la familia de mi mamá ha transitado desde Titiribí a Nueva Jersey, o bien buscando alternativas económicas o huyendo de la guerra. 


\title{
19. ¿Es la Biblia tan solo un buen libro?
}

\author{
Hemos existido, dice nuestra leyenda; de algunos deseos nuestros \\ nació esta ciudad. Luchamos contra fuerzas hostiles y un dia, \\ enflaquecidos, nuestros brazos dejaron caer las riendas. \\ Michel Houellebecq, Elmundo como supermercado
}

Escena 1. Exterior/día/un mirador del pueblo. Ante la cámara, Gabriel Fernández (grabando. Acción):

—Un saludito desde aquí para todos mis paisanos de Titiribí, Antioquia. Pa' que ruede este casete allá en Bolivia y en los Estados Unidos... y conozcan el pueblo. Un pueblo muy bonito donde nacimos todos los Fernández que, aunque estén lejos (no lo olviden), vuelvan como nosotros estamos volviendo en esta excursión EXTRAORDINARIA..., porque fue aquí donde nos conocimos todos, donde nos tomamos la primera aguapanelita, montamos a caballo y oímos la primera misita.

\section{Corte}

Se trata de comentario en in (o frente a la pantalla) del tío Gabrielito, ante la cámara que recobraba imágenes para la posterioridad mientras se respiraba cierta nostalgia. Volviendo al pueblo donde nacieron todos los de la familia Fernández Quiroz (la familia de mi mamá) no solo encontramos calles, cafés y casas con historias; la cabeza se puso a recordar, y se recobraron emociones, y se convocaron sensaciones: la tía Carmen buscaba "sitio viejo", el lugar donde se fundó el pueblo. Rubiela quería pillarse de lejos el cementerio como adivinando ante un mapa, y Gildardo queriendo ver a "cañahuate", un primo suyo... La cámara desde el microbús en que viajamos, haciendo panorámicas del pueblo aún en la distancia, y con su lente metiéndose en casas ajenas: las que hay por toda la carretera. Son casas de baños afuera, o separados de las casas, de muchas ventanas, humo azul de la cocina, perros braveros a la entrada de algún zaguán... Y el tío Gabriel acompañado de "la 
mona" (su mujer por muchos años) mirando y mirando el monte trazando imaginariamente los caminos, caminos con los que hace poco se encontró de nuevo...

-Fue una vez con Iván. Nos quedamos casi una semana por todo este monte andando...

Escena 2. Transición de varios días Exterior/Día-Noche/campos entre Titiribí, Bolombolo...

Por la llanura, como Quijote y Sancho arrojados contra el viento, Gabrielito e Iván a caballo por esos campos entre Titiribí, Bolombolo y algún otro lugar reinventando rutas, viejos caminos, rehaciendo esperanzas, recobrando sueños y hasta viejos olores: el tiempo como una mariposa deseando ser oruga otra vez. Inocente y terca la mariposa esa, tratando, tratando, y como ya no hay seda que la cubra, se enrolla en sus alas: lo que le queda, pétalos de flor que vuela, abrazo acogedor que a veces se tiene que dar uno mismo: el tío Gabriel alojado en sus recuerdos habla como cantando, siendo tierno en el relato de un tiempo tierno y duro a la vez.

Por disolvencia: una imagen se funde con otra.

Escena 3. Exterior/Día/un mirador del pueblo. De nuevo ante la cámara Gabriel Fernández (grabando. Acción):

- Para poder que nos llevaran al pueblo el día domingo, desde el día sábado nos mandaban a bañar, nos daban jaboncito bueno: JABONCITO DE OLOR; por eso me acuerdo de la canción: "Mañana es domingo / deja que me lave / despacito, mamá / con jabón de olor...”. Nos bañábamos el sábado pa’ bajar el domingo al pueblo. Eran tres o cuatro horas de camino para llegar, entonces teníamos que salir temprano y llevábamos huevitos para vender en la cafetería y con eso nos tomábamos el desayunito en la panadería.

Corte

El tío Gabriel me sorprendió con su erudición ante cámara: frescura total, amplio dominio, y por todo lo mucho que tenía para hablar, sobre todo por eso. Y resulta notorio porque él habla poco en una reunión familiar, siempre es "La Mona", su mujer, la responsable de hablar... "La Mona" es una mujer a quien le sobran las sonrisas. Y habla poco el tío porque poco es cruzable con los demás, salvo recordar o recochar. Mi tío Gabriel es el único evangélico en una familia tradicionalmente católica. Y dice que se metió a eso dado un claro interés por las sagradas escrituras que lo acompaña desde muy joven. Y descubrió con el tiempo que la religión católica no tiene como meta el principio del cristiano: "Vivir según enseña la Biblia". Y para ilustrarse, me explica por ejemplo la idea que circula frente al infierno: “... es una invención de los hombres, sin duda”. 
Escena 4. Exterior/Tarde/Patio de la casa de Gabrielito

Dándome la espalda, sin pretender dejar ahí el tema, Gabrielito arregla las jaulitas de sus pájaros: pericos y canarios de todos los colores que adornan su patio con sus colores y cantos...

- ¿Qué padre pone las manos de sus hijos sobre el fogón? Es falso todo aquello de un lugar donde la gente se quema y padece...

- Pero debe haber un sitio para los lamentos...

Pienso, por ejemplo, y se me vienen a la mente algunos dibujos de La divina comedia, y los sollozos del poeta, la creación de un católico militante. Allí, se narra cómo las almas esperan la redención o su segunda muerte. A su manera, el tío también se queja, o expone como ejemplo algo que puede marcar la diferencia entre los rituales católicos y las creencias por las que él se ha decidido. Las diferencias pueden notarse, pues como si se tratara de un plato servido a la mesa, un plato al alcance del paladar, la Biblia por lo menos hoy se pueden probar.... Antes a nadie le era permitido leerla. La Iglesia católica no lo convenía... ¿ ¿ por qué? Se pregunta el tío aun cuando hablamos de hace muchísimos años...

En el año 777 de nuestra era, los tiempos de Carlo Magno, el unificador de la Europa cristiana, los sajones eran vistos como paganos a los que se tenía que convertir mediante el bautismo... sin previo aviso, sin opción a preguntar de qué se trata eso... Tomen. Háganse creyentes... Pero mi tío, que fue criado en un hogar católico, preso quizás de la herencia y la tradición, alcanzó a su manera el conocimiento requerido, aquello que le antojaba: la curiosidad después de haber sido la ñaña de mamita Laura, una matrona muy rezandera... Ni eso, ni el tener una hermana monja en casa, pararon a Gabrielito en su búsqueda. Carlo Magno bien tenía en sus manos la fuerza y la creencia de gozar del beneplácito de Dios. Era fuerte y hacía convertir a los paganos, en nombre de Dios. En la familia Fernández solo habría un poco de indiferencia. Quizás se creía, a lo mejor se cree todavía, que los equivocados son los de otra religión y que Dios a ellos no los acompaña, ¿o se trata de otro Dios?

- Qué una misa por mi mamá, que una novena por aquel, y yo que no. Yo a eso no voy... El muerto, muerto está y nada puede hacer por nosotros.

Retoma. Escena 4. Exterior/tarde/patio de la casas de Gabrielito.

-A mí me gusta atender la visita en el patio, como en las casas de antes. Aquí me distraigo con los pajaritos, quizás sea porque ya tenemos el don de preferir cosas tranquilas, así como le pintan a uno el paraíso...

El tío Gabriel tiene 52 años. Desde hace unos 30 es cobrador en el Hospital San Vicente de Paul. Le toca ir a las aseguradoras y en medio de mucho papeleo hacer 
efectivo los cobros... Dice que lo pusieron Gabriel, recordando a Gabriel Ángel, uno más de la casa que no alcanzó a ser, murió... Está casado con Amparo o "La Mona" como casi todos le dicen, una mujer a quien conoció a través de otra mona, la hermana de Amparo, de quien Gabrielito era compañero en un colegio nocturno:

-Un día fuimos a ver un partido de fútbol por allá en Bolivariana y la conocí porque la hermana la llevó. Ellas vivían por donde hoy es el Éxito de San Antonio, en unas casitas que había por ahí...

Sin embargo, insistía mi tío en hablarme de la Biblia. Como a muchas, no le dije a él por qué de tanta preguntadera. La razón de mi visita fue prestarle el video que se logró en la excursión extraordinaria a Titiribí. Creyó él que mi inquietud por su vida iba tras otras cosas...

—¿Por qué recordaste que en Titiribí fuiste a la primera misa, siendo hoy otro tipo de creyente?

- Porque antes no tenía uso de razón. Cuando adulto me busqué lo mío y lo encontré. Me siento bien. Fue mi decisión. Lo que antes era una tradición en la que nunca te pedían consentimiento: que los papás lo llevaran a uno a oír misa... Y eso es algo que hace parte de uno.

- ¿Y los abuelos dijeron algo cuando creciste y te cambiaste?

- Habrán quedado desconsolados, pero qué se va a hacer, sobre todo mi mamá. Luego de que yo la acompañara a todas las misas, de que le hiciera los altares y, en fin, todo aquello...pero vea, mijo, léase esta revistica para que se oriente más y luego volvemos y hablamos. Se llama ¿Es la Biblia tan solo un buen libro? A mí me gustó mucho. ¡Léasela! A ver si usted también se ilumina... 


\title{
20. Donde quiera que uno esté hay que trabajar...
}

\author{
La realidady los enigmas de nuestro viaje no tardaron en \\ sacarnos de aquel estado de sublime éxtasis. La primera \\ pregunta, y la más importante: ¿por dónde hay que ir? \\ Ryszard Kapuscinski, Ébano
}

—¿Oíste, Iván, por qué fue que te viniste de Segovia?

- ¿Que por qué?

— ¡La guerrilla nos iba a matar!

Y Nora contrapone:

-Eso fue lo que dijeron las hermanas de éste...

Nora es una mujer de estatura baja, delgada muy delgada, muy flaca, siempre de cabello corto, más bien motilada como un chico. Es la esposa del tío Iván. Señalaba Nora a don Iván, uno de los mayores de la casa de mi mamá, que apenas me mira me guiña un ojo por encima de ella, como para que no le preste atención... Entonces yo me acerco y le pregunto por la verdadera razón de su aparente exilio de la montaña... y él no tiene problema en contar, así seco y concreto, tal y como es él:

- Qué me iba a quedar por allá, en el monte, con todos los muchachos ya grandes, organizados, viviendo por aquí en la ciudad... O en el pueblo.

Estamos en el negocio de mi tío Iván: un quiosco ubicado en una terminal de buses donde se lavan los buses y las busetas que bajan la gente del barrio al centro de la ciudad. En el quiosco se vende agua para tomar y para lavar los carros; gaseosas, fritos y mecato... Y la verdad tal vez resulte fácil una historia en medio de todo eso. Sobre todo en estos días en que el chuzo se compone de nuevo, luego de una racha mala. Las busetas apenas regresaron hace unos días, y de ellas depende el movimiento de este lugar. 
Hace por lo menos unos dos o tres meses atrás las busetas tenían que subir pasajeros y estacionarse de una vez allá arriba en El Triunfo o Bosnia para los conocidos del ambiente bélico que se respira en esta zona periférica de Medellín... Y entre hijueputazos y madrazos de todos los colores y tamaños, "el viejo" — como le dicen todos aquí a don Iván- despacha un café, un refresco, una empanada, un cigarrillo y hasta le presta la candela a más de uno de esos que gustan de prenderse un mariguano en medio de la jornada laboral: sus clientes de planta, además de los choferes, son los alistadores de los buses: hombres jóvenes, descalzos, sin camisa (y, por ende) con las marcas del justiciero sol a sus espaldas... manos ennegrecidas por la grasa y el pantano de por debajo de las carrocerías y las llantas, hombres hechos jabón que bailan y cantan salsa unas veces, vallenatos otras... trabaos casi siempre... y danzando entre los carros ya listos y encendidos, probando motores, con los equipos de sonidos retumbando... chequeando baterías...

$\mathrm{ran} / \mathrm{ran} / \mathrm{ran} .$.

Y mi tío por encima del bullicio, gritando... una escena de puras atracciones:

-Esas putas mangueras están mal conectadas. Vea cómo botan el agua manada de malparidos. A ver... quién va a venir a arreglar esto, pues...

Y llega el cucho que hace chance y, como si nada, el tío se baja de la bulla, y no menos acosado le dice un número, aclarando que solo lo hace pa' que el cucho ese no pierda la venida... Oigan a don Iván, pienso, no conozco a otro que le meta tanta plata a la suerte... Y que no se desmotive de ganar tan poco, o nada cada año.

- ¿Cuánto jugas en loterías, tío?

-Ayer le metí 4000 hijueputas a eso, pero... i¿pa’ qué? Si es más lo que se pierde!

Un mansito de estos que lavan los carros entra al negocio y paga el agua: 500 pesos. El tío desde siempre ha cobrado a los alistadores de los carros por enchufarse a la canilla del negocio. Eso, a la final no se pudo seguir haciendo después de un tiempo, sobre todo cuando el barrio y el cuadradero de los autobuses y colectivos se pusieron más calientes de lo normal, más caliente de lo que siempre ha sido... Ahora, desde que de nuevo los colectivos estacionan aquí abajo, del otro lado de la línea de fuego, "Jersegovina", las cosas cambian...

Como las busetas se quedan todo el día esperando el llamado para el viaje, son los choferes los que pagan el agua, de paso desayunan, almuerzan y mecatean... Entonces el tío improvisa un listado de las busetas, por sus números, sobre un cartón de cigarrillos donde chulea las que pagan, deja en blanco las que deben... la 306, 307,316 y otra más. De a 500 pesos por lavada, y a 100 de cada cigarrillo, de lo que 
valga la empanada o el desayuno... De eso y de todo lo que vende es que vive y pasea yendo a San Cristóbal donde Carmen, y de pronto hasta "cachonea" por ahí y, obvio, paga servicios y lleva comida la casa... Aunque reniegue parejo de esos hijos que poco le ayudan; pero por los que fue que finalmente se vino para la ciudad...

-Donde quiera que una esté hay que trabajar, mientras se pueda, hay que trabajar.

-Y aquí, ¿cómo te va?

-Bien. Ahora sí se puso bueno esto otra vez...

Y bajando la voz, me cuenta que unos fulanos no dejaron volver a subir los microbuses hasta "Bosnia", que porque como ellos son los dueños de todos los buses que también suben hasta allá, las busetas eran las que bajaban llenas y los buses siempre vacíos....

- Pura envidia. Y las busetas desde aquí siguen yendo llenas pál centro, y solo los buses van hasta "arriba" y para ellos puede que mejore la cosa, y así los fulanos dueños del barrio lo obligan a uno a montar en lo que ellos quieran... Y bueno por eso me está yendo ahora como mejor.

Cortando la carne a las carreras para los almuerzos que también vende, ofuscado por el solo hecho de estar allí entre los fogones encendidos, abriendo el enfriador, soportando todo —-incluso la grosería-, el tío se queja cuando se ensolva el quiosco de puro olor a bareta.

-Así trabajan esos malparidos. Trabados a toda hora...

— ¿Cómo son ellos trabados?

- ¿Cómo? ¡Todos locos!

Dice el tío un poco exaltado pero solo para imitarlos por los visajosos que se ponen, que quieren guardar las herramientas debajo del enfriador o entre las ollas, o arriba entre sus tarros... Y es que estos manes parecen en el cuartel, escondiendo el jabón y las estopas porque el que se duerma, perdió...

- ¿Y vos no quedás trabado con ese humo todo el día? ¿No te da cómo curiosidad el aroma?

Y el tío apenas se sonríe. Yo solo atino a decirle que a lo mejor, cuando le obra el humo ese, ya empieza a tratarlos mejor, sin tanto insulto. Y aún más se sonríe don Iván, y me mira y yo no lo dejo de mirar...

-Oíste, tío, ¿y con la guerrilla cómo era la vuelta, se manejaban bien o no?

Y la respuesta la elaboran entre los dos, la Nora y el Iván. Cada uno da su versión. Una versión en la cabeza de cada colombiano desplazado por razones, además de las conocidas... de algún lugar. Cualquier día uno se tiene que ir... 
- Se les hacían sus mandados: unos mercados que pedían y sin problema.

-El Ejército sí se portaba mal, pues sabía que uno les ayudaba; pero era que nos tocaba... Eran otros tiempos.

$-¿ Y$ con los paracos?

- Humm, donde hubiera paracos por esos días nos hubieran matado... No ve cómo matan y matan gente que dizque por ser auxiliadores de la guerrilla. ¿Qué puede hacer uno con un fusil apuntándole en la sien...?

Un chofer se entra hasta el mostrador, abre el congelador y toma una gaseosa, mientras va pidiendo un chorizo para comer...

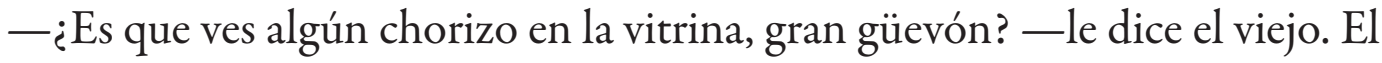
chofer contesta:

-Pues me fritas uno, jombe!

- ¿!Y si lo vas a esperar!?

—¿Cuánto se demora?

Y el tío mira la hora: como que cae en cuenta del tiempo y su ineludible paso afincao hacía el fin, y le dice a Nora: "pilas con esas papas". Ella lentamente se mueve hacia el fogón y yo decido mejor partir... La salida, un par de alistadores de carros piensan dónde esconder un pote grande de jabón, el jabón que casi todos usan. Me miran. Yo los miro, y me voy saltando los charcos de agua ya sucia por el tierrero de los autos... Alcanzo a oír a otro chofer que se queja de que no se puede mear en el baño por un chorro de agua que hay ahí. Mi tío vuelve con la cantaleta.

-Estos malparidos, ¿es que no van arreglar esa güevonada o qué? 


\title{
21. Ellos tienen su inglés y lo entienden a uno
}

\author{
We led a sheltered life out there in the suburbs. New York was \\ only twenty miles away, but it could have been China for all it \\ had to do with our little world of lawns and wooden houses. * \\ Paul Auster, The Locked Room
}

En las dos oportunidades en que el tío Mario ha estado en Nueva Jersey, donde sus hijas Nelly y Mery, como que se las ha pasado no más que hablando en español. Y aun cuando muchos aprovecharían un viaje de esos para aprender otro idioma, dado los beneficios culturales que tendría, sin destacar los económicos, al tío eso como que poco le importa, y eso porque sin el idioma ha podido trabajar. La última vez, en solo tres meses, se consiguió algo más de 1500 dólares.

—Primero — cuenta el tío — 'tuve trabajando pintándole la casa a la suegra de Nelly, después empacando una mercancía para llevarla de un almacén a otro. Eran muchas cajas, entonces eso fue trabajo como de una semana. También 'tuve por ahí podando jardines y, bueno, me conseguí unos dolaritos con los que les puse puertas de madera a las habitaciones de la casa en Colombia. La pintura sí fue una plata que me mando Mery en diciembre...

- Vos has trabajado toda la vida, ¿no?, tío.

- Toda la vida, mijo, toda la vida... ¡Desde chiquito!

Mi tío Mario tiene 65 años; es el segundo en la familia de mi mamá, después de Iván, si hablamos de los hombres solamente. Fue el último en dejar el pueblo de Titiribí, al sur de la provincia... Solo emigró a la capital de la montaña después de muerta mi abuela Laura, y eso dizque porque no le gustaba venirse pa' Medellín a

* “Llevábamos una vida protegida en los suburbios. Nueva York estaba a solo veinte kilómetros de distancia, pero podría haber sido China considerando lo poco que tenía que ver con nuestro pequeño mundo de jardines y las casas de madera". 
pagar arriendo. Vivió un tiempo en la casa de los abuelos en el barrio El Pedregal, hasta que consiguió un lote por los lados del 12 de Octubre, un barrio más alto en las laderas occidentales de la ciudad. Ahí vive todavía, en una casa a la que todavía le meten plata: los dólares que hacen las muchachas en Nueva Jersey y lo que le deja un puestico de mangos que desde hace años tiene junto a la iglesia del barrio El Pedregal.

— ¿Qué hacías en el pueblo, allá en Titiribí, tío Mario?

-Un tiempo 'tuve trabajando por allá en una finca, sacando cabuya.

- ¿Cabuya? Yo sabía que en Titiribí era posible el café y al caña de azúcar; pero de la cabuya...

-Ah, pues eso sale de la penca. Uno mete cada hoja y la máquina esa...

- ¿Un molino como lo que se usan con la caña para el guarapo o qué?

-Humm, no...¡ Una máquina para hacer cabuya, llama eso. Tiene una cuchilla o algo pues... como de filo. Empuja uno la hoja hasta el medio, y sale una tira. Saca la hoja y la voltea y vuelve a meterla... Y así.

- ¿Y lista la cabuya?

-No. Eso hay que lavarlo y después ponerlo a sol. Se trae pa' Medellín y ya con eso hacen costales y todo eso, son bultos de fique lo que uno termina haciendo en la finca.

-Y ¿qué te tocaba hacer en todo ese proceso?

-Yo hice de todo: cortar, meter al molino... También en el lavado y la extendida, HASTA CARGUÉ LOS BULTOS; pero eso era cuando yo vivía en el campo, porque cuando me vine pa'l pueblo, trabajaba recogiendo café, y los fines de semana, sacaba un puesto de ventas de mangos en el parque.

- ¿Y fue que conseguiste casa ahí en el parque?

- Primero sí pagaba arriendo, después compré una casita que vendí luego pa’ venirme para Medellín.

- ¿Y en el campo dónde vivías?

-En la casa del patrón.

- ¿Con toda la familia?

- iClaro, hermano!

El tío también cuenta cosas sobre Nueva Jersey, que ToDo es muy bonito, aunque no le ha tocado las olas de calor:

-Dicen que son épocas muy bravas. Ahí de pronto bajábamos a Nueva York y no más cuando se trata de pasear, de conocer... 
—Y eso de bajar a Nueva York... ¿es como si uno fuera al centro de la ciudad desde aquí, o qué?

Que todo es bien frío. Tanto así que la gente no hace fiesta en la calle, como por aquí. Que todo el mundo es en la casa o en las tabernas. Las calles son frías, solas y blancas por la nieve

- ¿Aprendiste a decir algo en inglés?

-No, ah, qué va. Lo mejor de por allá es que ellos tienen su inglés y lo entienden a uno. Hay quien hable los dos idiomas. Entonces pa’ qué.

- ¿Ya no sacas tu puesto de mangos en El Pedregal?

-Sí, pero los sábados y domingos. Esto ya ta’ muy malo, hermano. Mejor me quedo por aquí.

- ¿Cuándo regresas por allá?

-Cuando se mejore Luz.

Luz, su esposa, se accidentó hace algunos meses: rodó por unas escalas y se fracturó. Solo puede caminar con la ayuda de un caminador; por eso en la casa del tío permanece a diario Miriam, otra de sus hijas, y con ella, algunos de los hombres: Óscar, Jairo..., y mucho peladito, entre ellos Andrés, el hijo de la Mery, que un día viajará adonde su mamá, allá en Nueva Jersey.

Me dice el tío que se ha hecho de todo y nada que lo dejan salir —o entrar, pienso yo-. Viendo al pelao ese, recuerdo a la prima Mery, ella igual que Nelly, se la llevaban muy bien con mamá cuando eran más jóvenes. Sobre todo Nelly. Una vez, no sé por qué, la Mery amaneció en casa. Yo era un chino de unos pocos años; pero recuerdo que ella era muy linda, y se desvestía en la habitación de mi hermano y me ordenaba taparme con la cobijas. Yo obedecía, entonces la imaginaba desnuda, solo la imaginaba. Finalmente era yo obediente o, a lo mejor, muy dormido... Su piel era muy blanca, todo su cuerpo también... Podía imaginarlo.

Antes de despedirme le pregunté al tío Mario que cómo así que en sus tiempos mozos a él le decían "Cucharada", allá en Titiribí. Él apenas se sonríe diciendo que la gente tiene ese vicio de rebautizar a los demás por cualquier cosa; pero yo le digo que conozco la razón, y que la verdad no es que sea cualquier cosa:

- Que porque te metías en cualquier conversación y hasta opinabas.

— ¿Vos cómo supiste eso, muchacho?

—Estuve en Titiribí hace algunos días.

Y apenas se sonríe el tío Mario, de nuevo...

—¿Qué hay de tu papá, muchacho? — me pregunta el tío como para finalizar la conversa en torno a sus aventuras-. ¿Sigue bebiendo todos los días? 
- ¿Claro!

- ¿Y quién de ustedes le sacó el gusto por el trago?

Mi tío de cabeza calva ya, cubierta con un sombrero, igualito a como hacía el papito Gabriel, continúa preguntando, y antes de responderle, viéndolo, pienso...

— Todos dicen que mi hermano - es la respuesta que le doy.

- ¿No te pensás ir por allá, muchacho? Hoy en día, pa’l que estudie o pa’l bruto. Aquí en Colombia no hay nada que hacer...

Yo asiento mientras le digo que a lo mejor sí me vaya; pero, pensándolo bien, que lo que es ventaja para el tío Mario, para mí no lo es tanto. Qué pereza estar rodeado de latinos, colombianos para más señas o cubanos en el mejor de los casos, todos hablando español. Mejor me quedo aquí o me regreso a La Habana. 


\title{
22. De recuerdos, memorias y nostalgias
}

\author{
Cuando se acerca el mediodía, las sombras son todavia bordes \\ negros, marcados, en el flujo de las cosas, y están dispuestas a \\ retirarse quedas, de improviso, a su armazón, a su misterio. \\ Walter Benjamin, Discursos interrumpidos I
}

-¿A qué huele?

- ¿Como a algo dulce!

Sí, un recuerdo dulce retorna a mí, vistiendo la camisa azul marino que me mandaron los primos de Estados Unidos. De ellos tengo un recuerdo muy vago de hace muchos años que vieron junto con la tía Oliva y su esposo Ovidio. Su equipaje y su ropa, todo olía dulce, dulce.

Recuerdo también una buseta roja de transportes Castilla — que el tío Jaime había conseguido - en la que fuimos a recogerlos al aeropuerto. Tal vez haya sido para el entierro la abuela Laura. Les llevamos flores. Tendría yo acaso unos nueve o diez años. Por aquellos días también soñaba con ir a Nueva York, como muchos en la familia... pero yo lo pensaba porque creía que todo allí sería dulce: los dólares, los carros, Mickey Mouse, la estatua de la Libertad... Aquella vez, la tía Oliva solo vestía de negro. Sí, había muerto alguien. Ya lo recuerdo...

Pero después volvió en varias ocasiones. Vino a saludar, a celebrar... y vestía de colores. En algunas otras ocasiones su esposo Ovidio vino solo. Siempre nos saludaba. La tía Oliva, físicamente, se parece mucho a mi mamá. Y de sus hijos siempre he tenido la misma imagen. Un par de chicos blancos en un cuadro colgado en casa de la tía Irene. Willi es el menor. Me parece una versión masculina de mi prima Omaira. Ricky era el más grande, y no solo por su tamaño... Me parecía un típico gringo de las películas. Los imagino en primavera o en otoño, siempre 
entre flores. Quizá sea por las flores que esos recuerdos son dulces... Las flores son dulces y evocan sensaciones.

Estoy evocando recuerdos de mis primos y añorando volver a ver a la tía, que con los años le tiene más miedo a montar en avión. No sé si mis ancestros tuvieron tanta conciencia de dónde estaban y adónde iban. No sé cómo se sintió el abuelo en Nueva York. No alcanzo a imaginarlo por el barrio latino... Yo tampoco me veo paseando por Atlantic City. Pero imaginando nuestro transcurrir por los años entre pueblos y grandes ciudades de esperanzas y añoranzas de una vida mejor... escucho a mamá decir que la tía Oliva fue a buscar un lugar mejor... Mamá siempre ha querido ir a visitarla... Espero que así sea. Entonces me dirá cómo es el olor de Nueva York.

$\infty \infty \infty$

Este texto nos está dejando ver a la organización familiar en pleno proceso de construcción, deconstrucción y reconstrucción en medio de inevitables tensiones, conflictos, redefiniciones y otras ambigüedades que nos llevarán a transformaciones radicales generadoras de varias crisis, por cuenta de factores como los que se destacan a continuación:

- La democratización en las relaciones familiares, que debilita la supremacía de la autoridad paterna y fortalece la participación y autonomía de los otros miembros.

- Una diversificación en las formas de unión y las modalidades de convivencia, en especial el aumento de la unión libre con o sin residencia compartida, la separación y el madresolterismo.

- Un descenso en las mujeres separadas, como resultado de nuevas uniones.

- Un aumento en la viudez femenina, asociada con el notorio incremento de muertes masculinas por causas violentas, en especial en los varones entre 20 y 44 años.

- Fracturas irreversibles en la división sexual tradicional: el esposo-padre ya no se percibe como único proveedor económico de la familia, y el único representante legal y guardián de sus hijos, a la vez que la esposa-madre deja de ser vista como una exclusiva responsable de proveer cuidados y servicios domésticos.

- La disminución de la fecundidad, reducida en más de la mitad del número medio de hijos por mujer: de 7,4 en 1964 a 3,05 en 1993, 1,9 en 2012, lo que a su vez disminuye el tamaño medio de la familia. 
- Hay un número creciente de parejas que nunca tienen hijos.

- Mayor crecimiento de la participación femenina: incrementada de $36,84 \%$ a 49,07\% entre 1982 y 1995.

Estas transformaciones radicales las ha estado experimentando nuestra sociedad en el seno de las funciones tradicionales de la familia. Por ejemplo, la conyugalidad, entendida como convivencia vitalicia para organizar la sexualidad y garantizar societal y familiarmente la legitimidad, cambia en la medida en que la gratificación sexual no requiere ni la convivencia ni la legalidad de la unión. Surgen así, o se fortalecen, diversas formas de unión y de reproducción de la prole, como lo había planteado Engels (1884), en Elorigen de la familia, la propiedad privaday el Estado. Etiológicamente, familia viene del latín famulus, que quiere decir esclavo doméstico, donde la familia es el conjunto de los esclavos pertenecientes a un mismo hombre (Engels, 1884). Por tradición cultural, o por determinismo histórico, estos esclavos se liberan o se condenan aún más, como las madres, quienes están llamadas a asumir la carga filial en las crisis de los famulus. Así lo demuestra la creciente jefatura económica de la mujer urbana, heroína separada o madre soltera de la que esta etnografía nos deja ver algunos episodios. 



\title{
23. Esfuerzo propio
}

\author{
Pensó: "Son las gentes más enigmáticas del planeta... Educadas \\ para aceptar lo que la vida les traiga, sea bueno, malo o atroz". \\ Mario Vargas Llosa, La guerra del fin del mundo
}

- Fuimos nosotros los que nos los trajimos a toda la familia desde Titiribí. Jaime recién salido del Ejército, Oliva trabajando en la Noel, y yo en una casa de familia donde estuve por lo menos diez años. Hasta el 2 de febrero de 1964 cuando empecé a trabajar en el municipio...

Llegaron primero a Itagüí, luego a Envigado. Mi mamá estaba muy pequeña cuando eso. Ella es la menor de la casa de los Fernández. Que dizque se hacía en una piedra que había ahí enfrente de la casa, no más que a gritar:

-¿Quién quiele "jular", quién quiele "jular", yo "juelo"? (Por decir que quién quería jugar con ella)

A estas alturas, ya muchos en la familia conocen las intenciones de recolectar estas historias: armar un álbum, un libro, un inventario. Y no diré que le resta interés el que la gente lo sepa; pero sí es seguro que se crean muchas más expectativas. Y hablo pensando en todos aquellos que tienen algo que contar... y que ahora, de un momento a otro, lo quieren contar...

-A través de don Guillermo Villegas, un antiguo patrón, conseguimos la casa en El Pedregal. Era cuestión de conseguir un formulario para el Instituto de Crédito Territorial y llenarlo. Aunque se hizo, yo no le paré muchas bolas a eso hasta que tío Toño fue por allá al edificio del teatro Junín, donde hoy es el Coltejer, y vio el nombre de Laura Quiroz... Él sí dijo que miráramos por allá, que quién sabía que de pronto sí era pa' nosotros, y sí... así fue: salimos seleccionados y el lote que nos tocó quedaba por allá donde vive la familia de su papá, ¿La Tinaja...? Por esa cuadra, pero mi papáy don Guillermo dijeron que no. Que eso era muy alto y muy solo. Que 
era un solo pedrero... Entonces conseguimos uno como más central. En esa época, por la cuadra que nos tocó apenas éramos nosotros y la familia de Miriam Lotero.

— ¿Por qué apareció aquello a nombre de mamita Laura y no tuyo, si el formulario te lo dieron a vos?

- ¡Porque yo no estaba casada!

¡Y nunca lo estuvo! A mi tía Carmen Fernández Quiroz, mujer desafiante para la época, la mayor de la casa de los Fernández, además verraca por lo que verán... le tocó soportar durante varios meses el silencio del abuelo Gabriel, quien no le determinaba ni a ella ni a Omaira, que porque a Carmen la tuvo sin haberse casado.

- Se hicieron los papeles y mi papá empezó a construir...

— ¿Él solo o alguno de los muchachos le ayudaban?

- Jaime era el que le ayudaba. Gildardo estaba muy pequeño y a lo mejor sí puso unas piedritas por ahí, pero también había uno que otro trabajador.

Lo del Instituto de Crédito Territorial no era solo un lote ahí; era también un préstamo con el que se retiraban los materiales; la construcción sí era un esfuerzo propio; así incluso era como se conocía el programa de autoconstrucción. Y el papito Gabriel se quedaba hasta los ocho días de la semana trabajando en la casa de El Pedregal.

-Pa' que se iba a volver hasta Envigado...

- ¿Ya papito no trabajaba en alguna otra parte o qué?

-No, ya que le iban a dar trabajo a esa edad...

— ¿Y el negocio que tenía en la América, con el tío Jaime? — pregunta Omaira.

—Eso fue ya estando aquí... Era que su tío Jaime se lo manejaba, sino estoy mal...

Don Guillermo Villegas, una persona bien recordada por la tía Carmen, se había comprado un terreno por los lados del corregimiento de San Cristóbal, por donde quedaba la casa de Montecristo, y tumbó la casa que había ahí para hacerse otra. Todo lo que iba sacando y que servía, lo iba mandando pa' la casa de la familia de Carmen en El Pedregal. La tía recuerda sin hacer mucho esfuerzo que fue don Guillermo quien le habló al doctor Londoño, que tenía un hermano por allá en una fábrica de baldosas... Mosaicos:

-A ver sí me entregaban unas baldosas y yo pagaba con el sueldo, eso lo negoció fue don Guillermo, o que él las pagaba o que él mismo se encargaba de sacarme de mi sueldo algo. No de una, porque yo tenía que ayudar en la casa; pero que eso se pagaba y él respondía por si algo... 
- ¿Eh, y vos es que cotizabas con don Guillermo o qué tía, por que qué señor más querido, o no?

- Noooooooooooooo, qué va. Yo sí tenía un novio y fue él quien pegó las baldosas en la casa, porque es que siempre me las dieron. De segunda, casi regaladas... pero es mejor deber plata que favores. ¡Donde don Guillermo Villegas no me liquidaron! ¿Cómo iba yo a pedir plata después de todo lo que me ayudaron: la casa, el trabajo pa' los muchachos...? Porque lo que fue Iván y Jaime resultaron trabajando el Peldar, Gildardo por lo que estaba tan muchacho resultó pa’ mensajero en una empresa... Y así...

-Y si el tío Iván se vino para acá también, ¿entonces cuándo arrancó para Segovia?

—Él se vino ya casado, pero esa mujer que tenía sufría mucho de unos cólicos que, mejor dicho, a veces caía como un pollo. Entonces Iván todo aburrido. Un día, el suegro se lo llevó pa’ Megachí, o algo así —Vegachí, mamá, aclaró Omaira-. Y entonces se quedó en la montaña hasta ahora que se volvió y eso por los problemas que tuvo con la guerrilla, si no, allá estuviera.

- ¿Y, el papito, cuándo fue que resolvió irse para Nueva Jersey?

- Ya estábamos en la casa de El Pedregal, y Oliva ya se había organizado bien en los Estados Unidos. Papá se fue para donde ella y se estuvo cinco años.

—¿En qué trabajaba si estaba de edad? - Se inquieta Nando, el marido de Omaira.

— ¡Empacando mercancías! — Responde la tía, agregando, que la mamita Laura nunca fue allá porque nunca le dieron la visa.

-Y ya que hablás de mamita Laura, ¿qué es lo que más recordás de ella?

- Qué recuerdo yo de ella... Que era muy rezandera.

Todos los primeros viernes de cada mes, mamita Laura bajaba al pueblo a la jornada de oración del Corazón de Jesús. Salía a eso de las cinco de la mañana, cuando ya aclaraba el día. Se tardaba tres horas en llegar al pueblo para la misa de las ocho de la mañana y como eran tan pobres de dinero, a veces ni pa'l tinto tenía, y no más pasaba con un vaso de agua.

— ¿Y qué?, ¿era regañona la abuelita Laura?

— ¡No!, de pronto le hacíamos un motivo y nos quedamos en la calle hasta que llegara papá y así no nos pegaba.

Un día, la tía Emma, el tío Iván y Carmen, que eran los mayores, aprovecharon que mamita Laura le llevó el almuerzo a papito Gabriel: se sacaron un tabaco 
de los de don Gabriel. Al viejo, como le gustaba fumarse uno que otro de esos, y se metieron tremenda borrachera...

—Cuando llegó mamá, nosotros estábamos más malucos que un diablo. Y mi papá que se da cuenta que le faltaban tabacos. Entonces, va y pregunta por los que faltan. Debimos fumarnos varios porque pa' la borrachera y pa' que él se diera cuenta... En fin, mamá dijo que no sabía nada; pero se acordó de nosotros y dijo que... a lo mejor habíamos sido nosotros, que porque cuando ella había llegado de llevarle el almuerzo, nosotros estábamos vomitando. De la rasca, sería...

La tía Carmen se llenó de sentimiento al recordar lo acontecido en torno a la construcción de la casa en El Pedregal. No olvida al papito Gabriel cuando la acompañaba prácticamente hasta la autopista donde tenía que tomar buses de Bello o Copacabana para poder llegar al centro de la ciudad, y ella alzaba un pie para subir al bus y papito le ponía un zapato limpio, igual con el otro pie. Todo El Pedregal era un pantanero sin precedentes hasta la autopista Medellín-Bogotá, y solo cuando había verano, los carros arrimaban hasta donde empezaba el barrio... El agua debían sacarla de una pila que quedaba un tanto más lejos; por ahí donde quedaba también la capilla. Papito Gabriel tenía que madrugar como a las tres de la mañana si quería agua. En El Pedregal ya había mucha gente soñando con el progreso.

Esa casa finalmente tuvo que ser vendida, muertos los abuelos. Mi tía Carmen confiesa que prefiere no pasar por allí. Ya tiene dos pisos, cuando a ellos jamás les interesó construir más. Esa casa era grande. Recuerdo que tenía cuatro habitaciones, dos patios, una cocina grandecita, también con vista al patio y a la tarde...; el pasillo: un zaguancito y una piecita junto a los baños. Pero, más que el espacio, el sol sobre las botellas verdes de gaseosas Castalia, Gilda con su bata de baño cepillándose los dientes en el patio, desearía recordar más a la abuela: su cabello largo, muchas veces adornado con trenzas, su paso lento por su casa larga desde el jardín hasta el patio de atrás... Y al papito Gabriel... papito terminó por poner una tienda pequeña de la que solo recuerdo las Castalias y los chicles globo. Pasó el tiempo, y en sus últimos días terminé buscándole yerbas de no sé qué cosa, para unos baños que le preparaba mamá. Baños de agua tibia y yerbas verdes para sus piernas cansadas e hinchadas de andar el mundo. Mi abuelo fue hasta Nueva York desde Titiribí, igual que hoy hace el tío Mario...

Carmen siguió siendo centro de afectos y encuentros durante muchos años.... Como siendo una versión renovada de doña Laura. Hoy habita nuestro recuerdo... Se ha convertido en una estrella. 


\section{Mujeres en exceso}

¿Qué tontería cartesiana es pensar que los cantos de las aves son apenas unos gritos previamente programados que lanzan para indicar su presencia al sexo opuesto y cosas por el estilo! Cada canto de ave es una sincera liberación del yo al aire, que apenas podemos comprender. ;Yo!, dice cada grito, ;Yo, qué milagro! J. M. Coetzee, Diario de un mal año

De nuevo en casa de la tía Irene, sentados al comedor y afortunadamente lejos de la televisión. Aquí la televisión, como quizás en muchos otros muchos hogares, ocupa un lugar de privilegio, pues toda la familia le presta la atención que a lo mejor se niegan entre ellos. Aunque casos se dan en los cuales ni el más excitante avance de la modernidad rompe el diálogo intrafamiliar, y la familia sigue desempeñando su papel moldeante del individuo... sin massivas interferencias. Donde mi tía Irene, por lo menos, la tele está en la sala, y con eso se evitan que las palabras sean ahuyentadas de las alcobas cuando cada uno va a dormir.

En la sala se ocupan todos los muebles mirando la tele, y entre los comerciales de la novela Gotita de amor o las noticias de las siete de la noche, se hablan unos y se saludan los otros. Sobre la palabrería que se desata en la sala ancha de la tía Irene, y ante los ojos pintados de los abuelos en un par de cuadros que cuelgan en la pared, nos tomamos un tinto fumando de paso un Mustang. Las tiendas de por donde la tía deben surtirse de Mustang no más que para venderle cigarrillos Mustang a mi tía. Es raro ver a alguien fumando esa marca; ni mis primas, sus hijas, que como ella fuman... Ahora recuerdo que, de niño, le encendí un par de cigarros a mi tía... En la estufa: acercaba la cara al calor del fogón con ese pitillo en la boca, y aspiraba...

Beatriz llega del trabajo y su sobrina Sandra le sale al encuentro y le cuenta algo al oído. Se cuchichean en la habitación de mi tía entre sonrisas, jseguro que se trata de amores tanta risa! Luego las veré con la vecina Cristina, yendo hasta el teléfono 
público... Parecen novias cansonas. Y es que hace apenas un rato que la tía Irene ha debido regañar a Sandra por tardarse tanto en el teléfono. Ya venía don Arturo hablando, quejándose bajito:

-Esa muchacha no entiende, las visitas no se hacen por teléfono.

Pero como aquí lo que hay es un matriarcado, cuando habla Irene es cuando habla... la autoridad. Solo entonces se obedece. Dice la tía que es que eso nunca lo pierde un padre ante sus hijos: LA AUTORIDAD.

- Siempre él y ella merecerán el respeto de sus hijos. Luego de traerlos al mundo y haberlos levantado, es eso lo menos que puede pedirse...

Que los hijos necesitan amor, compañía; pero también templanza, dureza, criterio, exigencia, va contando Irene mientras se fuma otro cigarrillo. Sentada parece una reina la tía Irene, sosteniendo alto ese cigarrillo, aprobando y desaprobando las palabras de sus hijas sentadas ya a la mesa para comer... Un aire señorial se manda Irene hasta para hablar: manotea con la mano libre mientras habla, la otra de cuando en vez le acerca el cigarro a la boca justo en el espacio que le dejan las palabras... Y así se va confesando sobre el amor y cómo darlo. Cuando a ella le ha tocado ser dura ante los suyos, lo ha hecho. Y no deja de estar segura y convencida de lo que piensa, ejercer la autoridad sobre los hijos... Y no descarta volver a hacerlo si de nuevo siente que hace falta. Y eso que los hijos de la tía Irene ya marcan con el tres, treinta y punta... salvo Sandra, que en realidad es su nieta y no su hija... Aunque Sandra siempre le dirá mamá a mi tía Irene... Sandra apenas tiene diecisiete años; pero aun así, dice Irene, que hasta que pueda levantar la mano, la levanta si se siente irrespetada, desautorizada.

-A Sandra jamás se le mintió sobre Adriana, su verdadera mamá — dice la tía, cuando hemos logrado entrar en la conversa-. Siempre se le inculcó el llamarla mamá; pero es que Adriana era muy... ¡Adriana María nunca quiso a Sandra! Esa es la verdad... y yo me la aguanté mientras mi papá estuvo vivo. Él veía por los ojos de Adriana... Le daba pesar los castigos que yo le imponía, y no comía, intranquilo, pensándola cuando ella se desaparecía: "dónde estará esa muchacha, pasando hambre quizás y uno comiendo..., decía el abuelo Gabriel.

-Yo me tuve que salir del trabajo por cuidar a Sandra. Adriana solo le pegaba y la castigaba. Ella era solo la mamá para jugar; mientras no tuviera que prepararle un tetero o ir a bañarla, no había problema...

Si bien en esta casa se fraguó la idea de armar un álbum familiar, aquello ocurrió oyendo lo que casualmente se decía, lo que deambulaba por el aire; pero hoy buscaba algo muy puntual: saber de Adriana y Nolberto, dos de los hijos de 
Irene, y a través de ellos, de los demás hijos suyos de toda esta casa amplia y cálida por dentro habitada por mujeres en exceso: Irene, Beatriz, Lucía, Sandra, Luisa... Pronto otra nieta, ;seguro!

Hasta hace algunos días también Gloria y su hija. Los demás, Arturo y Gustavo (quien se ha alojado por unos días donde mi tía). De pronto pasan Nolberto y Luis, los hijos del primer matrimonio de Gloria... (No hay nieto que no busque la bendición de su abuela). Recuerdo a la Gloria tan enojada tan enojada que no hablaba cuando se devolvió para Bogotá. Gloria es una mujer negra como su papá Arturo, y tan guerrera como mi tía Irene: - Solo que un poco altanera - resalta Irene.

Ella, como Adriana, y quizás como Sandra, no se la deja montar de nadie, ni del marido ni de las cuñadas... Solo la tía Irene puede más, y como con ella nadie se mete, a la que no le gusten sus cosas, sus comentarios, o sus ideas, mejor se va. $Y$ así le pasó la última vez a la Gloria.

- Su altanería, su grosería no cuadraban en la casa.

Pero si de altanería se trata... a Arturo le parece una ofensa el que una hija tenga un hijo siendo soltera:

-Eso es como no valorar los sacrificios de los papás — dice.

Beatriz, por ejemplo, no piensa igual... Y esa controversia finalmente no genera problema alguno en esta casa. Solo un intercambio de palabras... dice mi prima:

- Papá, yo con usted no estoy de acuerdo...

Y Arturo la mira, pero ni él ni Beatriz dicen más...

Beatriz mira de nuevo la tele mientras va haciendo un lindo carrizo con sus piernas gruesas - morenas y aventuradas - Las cruza suave, como en cámara lenta, jala hacia abajo y con certeza la falda corta que lleva, no dejando escapar nada... ni mis suspiros.

De pronto me descubro: obviando su opinión, embelesado viendo solo sus piernas... Discutíamos sobre lo especial que puede ser una casa llena de mujeres, aun cuando para esas mujeres el asunto no tenga nada de especial... Entonces, recato mi postura y empiezo a analizar... viendo a Arturo... a través suyo, veo a mi abuelo Gabriel. El viejo se la montó a mi tía Carmen, porque tampoco estaba casada con don José... Arturo era sobrino de mi abuelo Gabriel... Humm... los Fernández... (Y yo, que soy hijo de mi papá... Humm).

Amanda rompe el silencio diciendo que tampoco está de acuerdo... Beatriz, Amanda y también Adriana tuvieron hijas sin casarse (¿Qué significa todo esto?) — ¿Con qué no estás de acuerdo? — pregunto-. ¿Con lo que dice Arturo? -recalco. 
- ¡No!, con que pueda ser especial una casa llena de mujeres...

— ¡Aaaahhhh, yaaa! Me lamento...

-Eso de muchas mujeres en la casa les permite a unas recostarse, echarse, dejarse ir, todas conchudas sin hacer nada más que dejándose atender...

Y se reserva nombres a la hora de quejarse. Amanda es una mujer delgada muy alta y más veloz que una gacela... de más joven era atleta, corría y jugaba basquetbol... La recuerdo corriendo detrás de mí, y eso que yo iba en la bici, volaooo... Y Amanda me alcanzaba.

Mi tía está mirando a sus hijas y las repara... como exponiéndomelas... y se alegra por Beatriz, que siempre encuentra trabajo; y se entristece por Amanda...

-Desde que perdió a Carlos Mario... Ay, qué pesar de mi hija...

Carlos Mario fue su último novio: un hombre radiante, contento... Un caballero fugado de la vida. Siento que no fue un juicio ni un reclamo la comparación de mi tía sobre el destino de mis primas... Según dice, hay encuentros que truncan la vida misma del que sea... Ahora mismo recuerdo a Carlos Mario con mi prima de la mano, su inquietud por mis historias y sus ganas de contar las suyas; pero la vida se le acaba a uno y uno todo sano, se queda no más con las ganas... Así como yo me quedé con las ganas de conocer más al primo Nolberto, quien en un cruce extraño de dos extraños también resultó fugado de esta vida.

—Estaría calvo, es casi seguro... — juró el tío Gustavo, un hermano de Arturo muy de la familia.

Él supo antes que nadie, y desde Titiribí, que aquí en Medellín había sido muerto un sobrino suyo, en un fin de semana, cuando la tía estaba en Bogotá.

- Para Nolberto la casa no existía de viernes a domingo; en esos días se perdía buscando adónde ir a parrandear... - dice Irene.

—Y ese último sábado jugó la Selección Colombia — recuerda Lucía- y como perdió... la decepción nos dio por silenciar la radio y la misma televisión...

Entonces de Titiribí llamaron a decir que en la radio hablaban de un muchacho asesinado a quien nadie iba a reclamar. Se llamaba Nolberto de Jesús Fernández Fernández, como el de Irene... y resultó ser el Nolberto de la tía Irene. Fue la misma Adriana quien lo pudo comprobar. Cuando supo la noticia, fue a la morgue y allá lo reconoció... Y que Nolberto (como lo es Beatriz) era la tranquilidad en pasta: el sello de la familia, dice y dice Gustavo: "así somos todos los Fernández: frescos, tranquilos".

De Adriana no se sabe nada desde que cuando Sandra hizo la primera comunión, y a pesar de su rebeldía y su grosería, la tía guardaba las esperanzas de volver 
a verla en los quince años de Sandra; pero Adriana María nunca apareció. Lo hará dentro de muchos años, con una nueva familia, verán...

Otro ausente de esta casa es el Darío. También resultó evadido por las calenturas que se respiran en los barrios altos de esta ciudad. Hoy también está en Bogotá... Pero al que nunca vi en esta casa fue a Carlos Arturo. Cuentan que de pelao él siempre prefirió el campo a estudiar. Iba todos los días a la escuela, pero jamás participaba de las clases y jamás a nadie le ocultó que no quería estudiar. Así, para evitar las mañas que enseña la ciudad, Carlos Arturo fue enviado a Titiribí, a trabajar...

Yo me explico ante la particularidad y lo especial que podría ser esta casa llena de mujeres. La mía, por ejemplo, llena de hombres, nos ha permitido a mi hermano y a mí jamás embalarnos ante los quehaceres, tan común y tradicionalmente asignados a las mujeres... Sin embargo, mi inquietud va más allá de los comportamientos más notorios. Sandra y Luisa pelean mucho, Sandra y Beatriz se la llevan bien, Lucía podría ser la más juiciosa y quizás sea Beatriz la que se recueste un poco... A Irene le parece inaudito que con tantas mujeres en una casa no se atienda debidamente a los hombres, aunque nunca ha permitido que hombre alguno se la monte a alguna de sus hijas solo porque le sirva la comida. El Darío alguna vez lo intentó...

-iY, seguro, no pudo...!

Arturo pasa la mayor parte del tiempo viéndome preguntar y descartar información; incluso podría decirse que ni siquiera le interesaba lo que se hablaba. Con cierta distancia me pedía mejor que viera en la tele al presidente Pastrana argumentando por qué Colombia merece hacer la Copa América:

-Vea, mire... por qué mejor no va y le hace un reportaje al presidente... Para qué quiere saber tanto...

Arturo es un hombre alto, grueso y moreno. De joven, sin duda, fue muy pintoso y el porte que seguro tuvo puede verse en sus fotografías. Arturo e Irene son primos, y según cuentan eso nunca significó líos, aunque eso de amor entre primos tampoco fuera la cosa más común. Irene sí tuvo miedo los primeros días, pero a la final ningún hijo bobo, ni con cola de marrano.

—Lo de Yiyo fue escopolamina, y lo de Byron, el hijo del tío Gabriel, de leer tanto lo Biblia. Esos son los únicos locos entre nosotros...

Eso lo dice Arturo y lo apoya Lucía, aun cuando Irene establece otra teoría: -Byron estudió mucho, siempre fue muy inteligente y se preparó; pero él no encontraba trabajo, donde poner su talento... Lo lanzó a la pensadera y eso lo volvió medio loco. 
Así, pues, no parece tan difícil establecer patrones que no se repitan en la familia, además de la tranquilidad de Nolberto y la de Beatriz, y la de cualquier ser humano... Uno no siempre esta agitado... Me parece clave ver que Irene castigaba a Adriana y eso a papito Gabriel le molestaba... y Adriana de mamá adolescente también castigaba a su bebé... Ahí está la vuelta de Van Gogh, apropósito de repeticiones, o espirales como lo propuse en Fumando mañas (Tapias, 2010):

—Los Fernández siempre hemos sido eso, frescos —insiste Gustavo.

- ¿Y quién lo va a contradecir? Solo quisiera notar que en una casa con mujeres en exceso como esta, hay que ver es cómo se transfiere el conocimiento del conocimiento que ofrecen... La vida, la experiencia y la familia, es decir, de nuevo... La existencia... La tarde pasando (se parece a la de ayer...), pasando ante la mirada serena de mi tía... La tarde anocheciendo y el cigarrillo cada vez más fumado... acabado como los otros cigarros fumados... La puerta abierta, la tele prendida... la vida pasando en la casa de mi tía Irene.

$\infty \infty \infty$

Para doña Virginia Gutiérrez de Pineda (1998), los estudios de familia en Colombia se han movido entre varias tendencias temáticas no excluyentes: por una parte, están los estudios de composición y tipo de familia; por otra, podemos ver la crisis asociada al concepto de descomposición social. Por último, una línea de desarrollo más reciente, considerada resultado de la interrelación entre las esferas pública y privada, donde se reconoce el papel clave de la socialización y supervivencia material y afectiva del grupo familiar, y los requerimientos que para dicho desarrollo tienen en relación con la oferta de servicios sociales. Vemos, una vez más, que en el abordaje de la familia convergen múltiples factores que inciden positiva y negativamente en su análisis, por cuanto esta no es solo un hecho social, sino una experiencia de vida, lo que dificulta la separación entre posturas valorativas y analíticas.

Este delirio socioantropológico quiere plegarse a la tendencia "crisis de familia" pero asociada al concepto de transformación, que también defiende la profesora Virginia aludiendo a crisis en medio de transformaciones muy violentas que podemos leer etnográficamente; por ejemplo, el asesinato de miembros de la familia o el enojo de los padres ante el madresolterismo de sus hijas. Esto nos obliga a considerar dos aspectos centrales:

En primer lugar, la crisis social y política que surge con la migración del campo a la ciudad, movimientos humanos en muchas ocasiones derivados de la violencia 
política y que se involucran en otras formas de violencia una vez llegan a nuevos espacios en la ciudad: asaltos... intimidación... y la propia violencia intrafamiliar. Y, en segundo lugar, la crisis en función del lugar que ocupan las mujeres. Información del Departamento Administrativo Nacional de Estadística (DANE, 1998), obtenida de encuestas a hogares en 1978, y el Censo Nacional de Población de 1993, dejan ver que el predominio de la familia nuclear, como forma en la que se organiza más de la mitad de los hogares en Colombia, disminuye a expensas de leves incrementos en los arreglos unipersonales y las modalidades extendidas. Es el caso de familias con nietos y bisnietos, o de mujeres madres solteras que se quedan o regresan a casa de sus padres.

La profesora Virginia desagrega esa información y encuentra cambios sustanciales, como la disminución de la familia nuclear completa (padre, madre e hijos); en tanto aumentan hogares con un solo progenitor, por lo que habría que incluir a padres abandonadores. Ahí podría observarse la crisis en torno a la función de la mujer, en cuanto vanguardia de la transformación de la función económica, con el hombre que se rezaga o se dualiza ante el sexo. Pese a todas las contradicciones y modalidades de cambio, la función sexual gratificante pierde su restricción prematrimonial en la mujer, que ha entrado a obtenerla desde edades tempranas. 



\section{Sus brazos gruesos desnudos sobre el muro}

Québestia fui, recuerdo. Pero recuerdo que me dijo:

"No te preocupes. Ya estoy acostumbrado. Creo que se le nublaron los ojos, y a mi, peor". Evelio José Rosero, Cucbilla

Como si el tiempo se resistiera a pasar, el láser del equipo de sonido del primo Alberto no deja avanzar normalmente los CD: se devuelven los temas musicales antes de terminar. No terminan porque se devuelven sobre sus notas y todo se hace una constante repetidera de un solo acorde, algo que no se hace molesto sino hasta después de un rato cuando nos damos cuenta de que Ray Barretto no para de tocar el mismo tumbao sobre las congas...

—Hummmm... No se cansa este Barretto. ¡Qué monstruo! — dice el primo.

El primo Alberto es un tipo gordo-gordo, pero según parece solo desde algunos años para acá. Aun cuando yo siempre lo he visto así, gordo-gordo y barrigón, como si se tratara de un Buda. A veces tiene la desfachatez de andar por ahí sin camisa con su inmensa barriga —el mundo - y el porvenir al aire... y se pilla uno que su cuerpo es proporcional al tamaño de brazos y manos gruesotas. El barrigón por lo regular viste de jeans anchos caídos atrás, camisas también anchas, usando botas y casi siempre motilado muy tuso.

- Pero antes de casarme yo más bien era flaco... Y también muy loco. Finalmente fue necesario organizarme, porque corría el peligro de no ser nada si seguía como iba...

Y es que el primo se la pasaba jugando dados, bebiendo y peleando por allá en Bello cuando apenas era un pelao, y peleaba tanto que a lo último tuvo que andar enfierrao y lleno de puntas. Según parece, eran muchas culebras las que tenía... Al final se tuvo que ir de la casa y fue a dar a El Pedregal, adonde su tío Fonso, es decir, 
mi abuelo. Yo jamás llegué a considerar realmente necesario, benéfico para uno mismo y su "calidad de vida", formar un hogar (y aún lo pienso). Si bien es cierto que no somos islas, como individuos también valemos. El primo dice tener siempre la sabiduría de escucharse en los momentos cruciales de la vida:

- Se trata de hallar el yo interior.

-Y ese "yo" le dijo un día que mejor se casara, de lo contrario...

- Nada de nada con esta vida de loco.

Esa sabiduría le permitió entender en su debido momento que lo mejor era estudiar; pero cuando terminó quinto de primaria, su papá le salió con que... ¡Ya no más!

- Mire a ver qué hace, usted ya está muy grande...

Alberto había ahorrado unos pesos de cuando trabajaba barequeando en Segovia por vacaciones de la escuela, para con esa plata ayudarle al cucho a pagar su estudio... Pero nada de nada tampoco... Pelaíto se fue de la casa y pelaíto también se casó:

-Yo tenía dieciséis años; Lucrecia, mi novia, era mayor que yo como por cuatro años... Doña Carlota, la mamá de ella, me dio el aire de la casa y ahí construí...

Y es que en El Pedregal no solo se salvó Alberto de las culebras callejeras, y de tanto tropel, sino que conoció a Lucrecia mientras sorteaba otra clase de broncas: las de la casa de mi abuelo. Escapado de la calle y su rudeza, Alberto terminó correteando al tío $\mathrm{H}$, lo agarraba y se lo llevaba al papito Fonso, que lo cascaba con un alambre... Dice Alberto que mi tío era tan grosero que una vez hasta le tiró la comida en la cara a la mamita Gélica.

-Ese día acompañé a su mamita a poner el denuncio allá en los Carabineros... al día siguiente lo encanaron en la correccional de menores...

Sin embargo, aun cuando el primo parecía neutral ante los conflictos de la familia que lo acogió, terminó empeliculao cuando la Melia apareció casada: que era un alcahueta, le decía mi abuela al primo, y él sin saber nada de nada...

- Melia sí me había dicho de su idea de casarse; incluso me pidió que fuera el padrino junto con Lucrecia, pero nunca supe más hasta cuando dijo que ya se había casado... Y fue a mí a quien se la montaron.

A lo bien, pienso que el primo podría resumir algunas anécdotas de la casa de los abuelos, pero se pilla uno que después esas mismas anécdotas lo dejaron mal parado. A lo mejor de ahí, de la experiencia, sacó el primo Alberto tan mala cara:

- Recién casado su papá, por ejemplo. Él me contó de una vuelta con otra vieja por ahí. En la casa como que escucharon y quién sabe qué pensaron; pero eso 
se volvió una calentura tremenda, todas aleteadas, la Melia sobre todo, me cogían a preguntarme sobre qué era lo que me decía Alberto y yo que no decía nada. Hasta su mamá se enojó conmigo. Yo a la final siempre reuní buenos argumentos para ser la mala compañía... La puta del paseo.

Un día apareció $\mathrm{H}$ como con ganas de cobrarle al primo las sapeadas y las carreras para cogerlo y llevarlo adonde el abuelo. Entonces lo llamó por el balcón y le fue diciendo:

-Alberto, Alberto, sacá lo más grande que tengas y vamos a matarnos...

Y Alberto sacó un machete ni el hijueputa de grande... Y casi mata al pobre $\mathrm{H}$, según cuenta él, que le abrió la cabeza y a punto estuvo de botarle un brazo... En ese brazo lleva el tío $\mathrm{H}$ una de las cicatrices más grandes entre las muchas que el callejeo le ha dejado por todo el cuerpo... Como la barriga del primo Alberto, yo creo que las cicatrices de mi tío $\mathrm{H}$ son como una página del libro abierto que ha sido su vida.

Pasado el tiempo y todavía pelao, el primo Alberto se pasó a vivir enseguida de los abuelos, donde Lucre, en el aire que le dio doña Carlota y desde ahí a batallar con nuevas broncas. Gracias a un hermano de Lucre, Alberto volvió a estudiar: se metió al Sena, a Mecánica y Soldadura. Camelló y se hizo a una casa prefabricada de la que hoy, dice él, lo quieren sacar... Después de catorce años, las cosas no han salido tan bien: el primo ha pasado por dos grandes crisis que le han significado deshacerse de las cosas más queridas y, obviamente, el amor también sufre sus quebrantos cuando no hay plata... Alberto dice que después de casado, con casa y dos hijas, lo demás era ganancia; sin embargo, esas ganancias se han ido gastando para poder seguir batallando, o sea que las ganancias esas vienen a ser como una especie de reserva para los tiempos malos...

Alberto tuvo que vender su colección de salsa. Unos ochocientos álbumes en pasta fina y grabaciones originales. Salió también de la herramienta, el soldador... La última mala racha duró como dieciocho meses. Solo ahí vendió más de cien de sus $\mathrm{CD}$..., y me da una tristeza que a mí mismo no me cabe en el pecho: sí, la familia puede salvarlo a uno, bien, pero hay que tener en cuenta que eso se voltea y termina uno salvando a la familia en detrimento de uno. Sacrificios que llaman, actos de amor... pero bueno, Alberto dice que todavía le queda algo de esa música dura — cantadora de verdades-golpeadora de almas-azaradora de mentes - callejera, música que a la final algún día espera volver a conseguir...

-Es que cuando las cosas están mal, hay que pegarse de lo que sea que tenga, de lo que sea que tenga... 
En esas andanzas callejeras que el primo aún continúa haciendo, farras que terminan comiendo morcilla en Balalaika a las tres de la mañana, el primo dice haber probado de todo y después de los años solo quedarse con el guaro. La bareta y el perico son solo fórmulas de escape a la realidad, cosas que ya no le interesan al primo, porque siempre es mejor meterle el pecho a todo... O si no, ¿para qué ese cuerpo de Buda gigante?

Ahora, con un nuevo empleo y esperando se enmienden los errores que con él se han cometido, espera arrancar de nuevo. De hecho, cree estarlo haciendo de a poco, entonces con la tranquilidad que lo caracteriza, el gordo-gordo se recuesta en el balcón de su casa a fumarse un cigarro mientras ve pasar a cada quien con sus preocupaciones y sus penas... Sus brazos gruesos descansan desnudos sobre el muro que recibe todo su enorme peso; justo ahí junto a la puerta de su casa prefabricada levantada sobre una terraza por donde se escapan los sonidos bulliciosos de la salsa que aún le queda y que pone a sonar a cualquier hora: un domingo en la madrugada, por ejemplo, aun a pesar de las vecinas, de la suegra y de las hijas...

Y borracho del desencanto que a veces lo habita a uno, o de la alegría que le otorgan unos tragos, el primo Alberto evoca la canción del hombre que salió de casa a las cuatro de la mañana directo al Pueblo de Morón, con un tabaco en la boca, pero que a Morón nunca llegó...

Así mismo, con el tiempo, como el hombre de la canción, Alberto se fue a algún lugar... dejando sola a Lucrecia y dos hijas adolescentes.

$\infty \infty \infty$

En el artículo "Cambio social, familia patriarcal y emancipación femenina en Colombia”, la profesora Virginia Gutiérrez de Pineda dice que constituye un lugar común asegurar que las instituciones y la cultura colombiana han cambiado aceleradamente desde la mitad del siglo pasado, y no se puede pronosticar fácilmente su estancamiento o dinámica. Conviene, sin embargo, focalizar áreas de transformación para ver aciertos y desaciertos que proyectan en la vida social esas transformaciones. Se me ocurre que en el área de las interacciones que he venido describiendo etnográficamente puede verse que si la famulus esclaviza, o prepara para la opresión, un acierto de sus transformaciones - léase también crisis - tal vez sea la independencia, más que económica, ética por lo personal, también política por el poder que involucra, mas... algo espiritual, si se quiere psíquico, que nos hace más conscientes de las consecuencias de nuestra acción: pequeñas luchas de 
emancipación ganadas, que brindan nuevos elementos para capacidad de maniobra, de acción, de agencia (Giddens, 1986), vital para (existir de forma cada vez más libre) la construcción de lo social. Ya sea por la fuga del padre, o de la madre... de la pareja; por su muerte violenta o natural... o por el deslizamiento de los sujetos entre roles que no asumen so pena de perder autoridad... poder... aprendemos a saber que estamos solos en medio de mucha gente.

Cuatro funciones familiares son, sin lugar a dudas, las de mayor visibilidad durante estos cambios: la económica, la sexo-reproductiva, la de germinación gratificante y la de socialización y crianza. Es necesario reiterar que estas transformaciones se encuentran íntimamente relacionadas con los cambios institucionales. La transformación de la función económica familiar, por ejemplo, su reasignación como rol a otro actor de la familia es, sin lugar a dudas, la que mayores repercusiones produce sobre las demás funciones, la estructura familiar y la relación de los géneros. No es una novedad entre nosotros el trabajo productivo de la mujer casada, fuera de las tareas relativas a la reproducción adscritas a su estatus y género, que han intervenido desde siempre en su quehacer.

La mujer fue parte del peonaje agrícola y en la etapa artesanal mantuvo desarrollos, bien como unidades productivas o como ayudantes familiares sin remuneración bajo el comando del marido, condición que le restaba figuración a su aporte, para después desempeñar la jefatura económica en procura del sustento de su prole, o en la viudez, en el madresolterismo o en el abandono marital.

También debe considerarse la profesionalización, el cambio cultural ante el trabajo de la mujer casada y la planificación familiar, como componentes que redujeron sensiblemente el número de hijos por mujer en edad fértil, junto al desplazamiento de la crianza hacia instituciones que le han permitido a la mujer permanecer en el trabajo fuera del hogar. Si por tradición cultural la madre está llamada a asumir la carga filial, y en las crisis de la familia esto demuestra la capacidad de jefatura económica de la mujer urbana, separada o madre soltera, es necesario comprobar si como consecuencia de la coproveeduría de la madre el padre actual se ha hecho irresponsable o es que, ahora, ante la denuncia femenina, se evidencia un problema que en el pasado permanecía encubierto.

También vale la pena preguntar y responder con investigaciones si el cambio operado en la función que analizamos estimula negativamente el desempeño del hombre en su papel de providente. Hoy parece que, a semejanza de la mujer patriarcal, el padre asume el estatus de mantenido, y que valiéndose de su poder tradicional, está tomando ventaja personal del aporte de su pareja para eludir su deber 
progenitural. Veremos a la mujer que huye a la sumisión a los hijos, al marido, y al hombre, eludido del deber...

Tales escenarios etnográficos ayudan a ver cómo esa transformación de la función económica, que promueve la coparticipación femenina, es fuente de duros conflictos, pues hacen referencia a algo más que el descargo que el hombre hace de su obligación de cooperación y que deja sola a la mujer en la cobertura de la función. Dos modalidades: la ya citada de cabeza económica femenina manifiesta y la forma encubierta tanto cuando la pareja no ha roto su convivencia como cuando la ha abandonado. 


\title{
26. ¡Esos ojos, muchachos! Esos ojos...
}

\author{
Shinji contempló el cielo cuajado de estrellas y aspiró hondo. \\ Entoncespensó: \\ “Pero no podría el dios castigarme por dirigirle una plegaria \\ tan egoista?". \\ Yukio Mishima, El rumor del oleaje
}

- ¿Y lo que usted piensa qué?, ¿lo qué usted siente qué?

- De todas maneras yo siempre estoy llamando a la casa a averiguar por los muchachos. No soy capaz de quedarme sin pensar en ellos, ¿estarán bien?

En su cartera, antes que nada, antes que sus documentos y esas vainas con las que uno se empapela de por vida (incluso antes que otros accesorios cuando se trata de mujeres), mi tía Hael tiene fotos de sus muchachos. Son algunos retratos de cuando eran más bien pelaos junto a algunos más actuales. De JF, por ejemplo, que ahora está bien gordo, tiene una donde luce su uniforme de patrullero prácticamente nuevo y de pronto otra de más pelao, en el colegio. Entonces me sobreviene un recuerdo de mi primo JF bautizado un día por el parche con el alias de "Mordillo". De nuevo miro a Hael. Sonríe muy sincera y muy tiernamente llena de orgullo enseñándome esa foto.JF es policía. ¡Y con lo mal que me caen los tombos!

Es una tarde especial, sin duda alguna, y aunque las palabras existen precisamente para expresarnos, las palabras en los labios de Hael se quedan cortas para lo que dicen sus ojos...

- Quisiera estar con mis hijos, siempre y cuando ellos tuvieran en cuenta lo que yo siento. Lo que pasa es que ellos creen que no más es el amor de madre, no más el amor de ellos, pero yo también necesitaba a alguien. Alguien que me hiciera sentir bien... El papá de ellos es una persona muy respetuosa, muy cariñosa. Él fue una persona muy especial, pero al parecer solo pensaba en él. 
—Fred — su hijo mayor - se preocupaba mucho por mí. JF quizás porque estaba tan loquito, pero siempre quería estar al lado mío. Él tiene cosas muy lindas, pero Mónica... MÓNICA... Vos sabés que Mónica siempre ha sido al lado mío también, aunque los primeros días de casada fue muy déspota conmigo. Ella tiene cosas muy buenas... Yo a ellos los quiero mucho, César, y me hacen falta; pero creo que nunca van a alcanzar a entender lo que yo sentía.

- ¿Y quisiera que algún día lo entendieran?

-¡Síín!

— ¿Te preocupa lo que alguien más piense, además de tus hijos?

—Sí, mis papás. Qué puedo decir yo de mis papás, César. Mi mamá, vos sabés cómo es mi mamá. Quizás ella... ¿Qué pensará? Aunque a veces estaba como al lado de Fernando... ¿Quién sabe qué pensará?

-Pero mi papito, por ejemplo, ¿no crees que él siempre ha sido más abierto?

- Mi papá, sí, por esa parte, sí... Lo que pasa es que a mi mamá hay que entenderla. Y toda mi familia, César. Obviamente me interesa lo que ellos piensen, pero sobre todo ellos que son mis papás.

- Si te encontraras a los muchachos, ¿has pensado en decirles algo?

-No sé. Yo sé que Fred siempre me mira como raro. Yo trato más con Mónica.

Y la tía se queda... mirando.

Y parece que dibujara en su rostro la cara de cada uno de los muchachos.

Y me quedo con el que logra de Mónica.

Nadie puede dudar cuán adentro los lleva mi tía Hael...

—Quién sabe ella, JF y Fred, ¿qué pensarán?

Esa pregunta no se la baja mi tía de su boca.

De su boca, donde protegidos por palabras de amor y suavizados por lágrimas de amor también... permanecen los recuerdos de sus hijos.

Tiene mi tía guardaditos a sus muchachos en sus labios.

-A mí me dicen que Fred tiene novia. Muy bueno que se casara — pienso yo-. De todas maneras, sé que se siente muy solo también... Yo digo que a veces... sé que beben en la casa y que lloran... Pero uno a veces siempre ve las cosas malas de las personas: ¡SIEMPRE! Y nunca ve el lado bueno. Quién sabe si algún día Fernando se sentará y pensará... Yo era así, Yo era asá... De todas maneras, yo me vine de la casa, yo dejé el hogar: para él siempre será una...

-No, tía, ni de riesgos. ¿Y lo que usted piensa qué?, ¿lo que usted siente qué?

-De todas maneras yo siempre estoy llamando a la casa a averiguar por los muchachos. No soy capaz de quedarme sin pensar en ellos, ¡¿estarán bien?! Por 
ejemplo, en lo que está JF ahora: eso de ser policía siempre es un trabajo muy peligroso; mi mamá dice que él es muy bravo, y usted sabe que a los policías siempre les llevan bronca... Y todos los días me pregunto que si ya estará en la casa o si estará trabajando todavía. Yo pido mucho por ellos. En el trabajo de Fredy también pienso mucho, cuando estuvo viajando y trabajando con ese señor Villegas, yo era pensando que... Fred estaba en lugares muy peligrosos... y Mónica, pienso que por qué a veces es tan grosera y tan malaclase... Pero ella tiene grandes cosas... Ojalá ella lo supiera. Me alegra que Fernando aún esté con mis hijos. Recuerdo que un día les dije que el papi era el papi, y él siempre los ha querido mucho. Me alegran que eso lo sepan, pero... Yo no sé si es que no han querido entender más o es que se hacen los loquitos. Yo sé que cometí un error... pero, itampoco!

- $\mathrm{Si}$ crees que se trata de un error, ¿cuándo uno se la juega por su felicidad?

- Pues, Fred ya estaba muy criadito, ya estaba trabajando. JF sí se quedó muy menorcito; pero como le dije a Fred una vez: "si Juan se dañaba, era por el tío Ed... y Mónica ya estaba casada.... Lo que yo puedo decir es que todo fue tan raro... Yo nunca dije que me iba a conseguir otro. Tenía mis problemas y me mantenía aburrida, pero que yo saliera a buscar otro... "una tripa”, como decía mi amá. ¡No! ¡Nunca!

Hael acoge en un pañuelo el llanto. El cielo se la ha pasado llorando desde hace un rato también. Entonces yo le digo que sin que nos importe mojarnos, caminemos... como para lavarnos o purificarnos, quizás ya muertos y enterrados escuchemos que llueve sobre nuestra tumba y nosotros extrañando el agua que no nos toca, que no nos moja, que no nos llega...

La tía me complace solo por algunas cuadras. Caminando, fuimos y vinimos por el centro y sus calles; caminando de la mano del sol primero, de la lluvia al regreso... Y pasa la gente huyendo, también nosotros después de todo, pero disfrutando un poco del rocío al que otros no atienden.

Antes de encontrarla, cuando la esperaba, me preguntaba ¿cómo estaría? Tenía tiempo de no ver a la tía Hael. Y se lo dije: "Estas tan distinta tía, pero muy bonita...” Entonces me regaló un confite y se colgó de mi brazo...

- Pensé que no vendría, tía.

-Usted dijo que quería verme... ¿ ¿No?

- Sí, claro, camine la invito a almorzar donde los Hare Hare...

Y toda la tarde pasó sobre las palabras, pero insisto en que los ojos dijeron mucho más.

¡Esos ojos, muchachos! Esos ojos, esos ojos... Tiene que verlos. 



\title{
27. Una caricia que después no reclame amor
}

\author{
Siento que cada una de mis fibras de carne se enojan si no las \\ dejo hacer el amor con una bala. \\ Helí Ramírez, La ausencia del descanso
}

El tío Raúl es uno de los pelaos de la casa de mis abuelos. Él, Hétor y Ed, de pronto hasta Willi, aparecen así, como niños, en las historias de viejas anécdotas como la del matrimonio en secreto de Melia, como las aventuras de Osorio o de mi tío $\mathrm{H}$. Donde los Tales, que son tantos, ha habido de todo, y estos que fueron primero los llorones también tienen sus historias. Raúl, por ejemplo, durante mucho tiempo terminó siendo el taxista de la familia, pues desvaraba a más de uno con carreras programadas por la misma familia, dizque para colaborarle al hombre: que recoja a las niñas de Ilsa, que lleve a Rigo a Niquía, que acompañe a César a grabar en el centro, etcétera, y es que resultaba hasta bacano tener transporte fijo, porque que fueran a recogerlo a uno donde uno estuviera no era cosa de todos los días... El "Mocho", como algunos le dicen al tío, dado que perdió uno de sus dedos de la mano derecha en una fábrica de embutidos, es hoy por hoy el jefe de personal del autoservicio los Tres Reyes, un minimercado que el primo Memo, un sobrino de mamita Gélica, tiene en el municipio de Apartadó.

Después de andar perdido un buen tiempo, Raúl reapareció en la casa de los abuelos, gordo, bien motilado y con la dentadura arreglada. Sus últimos tiempos fueron muy malos, según su propia evaluación. Dice que su familia nunca lo aceptó así: pobre y guerrero, como es él... Su esposa Patricia dizque anda en España camellando y de sus hijos, Santiago y Laura, poco o nada se sabe... Sin embargo, espera que los pelados se enteren de que él ha regresado por algunos días. Confía, pues, en que los chismosos del barrio les den aviso. 
Ahora, cuando su presencia goza de tener presencia, dice Raúl — muy defraudado, por cierto - , que los sueños son finalmente güevonadas, que uno lucha por ellos y a la final nada de nada... no quiere entonces el tío meterse con nadie y de las mujeres solo le interesa una caricia que después no reclame amor... Y se justifica mirando espejos cercanos, como el caso del primito que se ganó la vida y más de un canazo empapelando mulas... El primito ganó las lucas mandando gente pa' los nuevayores con merca, y una vez hasta él también se fue; pero la mujer no lo esperó cuando supo que lo agarraron: seis años y un día fue la condena; sin embargo, como el día podría ser un mes o un año más, la Jevita también voló a España para nunca volver... Hoy el primito, al menos, está con los hijos; al Raúl ni chance de eso le dieron. Según él, la familia de Patricia ha puesto a sus hijos en contra suya.

-A lo mejor me equivoco copiando las cosas de esta manera, pero nada me dice lo contrario.

En Apartadó se gana unos pesitos con los que vive bien, bebe y rumbea en el barrio Ortiz o en el Vélez que, según cuenta, son como la calle 70 en Medellín, calle para la fiesta con lugares como La Cuna del Son, si lo que quieres es oír salsa (esta no le puede faltar a un Tales), y muchos otros lugares donde no dejan de sonar vallenato ventiao.

-Allá todo es puro vallenato y pura AUC.

Dice Raúl que en ese pueblo ya lo conocen bien, sobre todo porque es el primo de Memo. El primo Memo es un bacán con todo el mundo: les presta fierros y surte gratis de munición a más de uno, y sus escoltas son de esos tipos que por ratos trabajan para los paras.

-Eso a la final es como una empresa, dice Raúl. He visto manes que en las referencias laborales ponen haber trabajado para las Autodefensas... Donde vivo, la cucha dueña del rancho es viuda; al marido se lo pegaron en un enfrentamiento y está esperando indemnización. Los Paras dicen que le van a dar veinticinco palos de los grandes.

Y, así y todo, cuenta Raúl que él quería camellar con ellos, con la certeza de que si se aburre, puede salirse sin tropel alguno, que ellos no son como en la guerrilla, donde si alguien quiere salirse... ¡Mejor lo pegan! Memo entonces es un personaje en el pueblo, y el tío Jesús, el hermano de mi abuela... ni qué decir. Cuentan en Apartadó que don Chucho fue de los primeros comerciantes en decirles a las FARC: “... señores, iyo a ustedes no les doy un peso más!”.

Entonces, como lo conocen por esa familia, al Raúl los Paras le dijeron que no fuera a rumbiar más por allá por el Ortiz, dizque hay unos infiltrados que hay que 
cazar; pero, según parece, se tienen que llevar por lo menos a unos doscientos pa' que la cosa quede bien y se pueda volver a respirar... Debe ser por eso que últimamente han masacrado a tantos parroquianos en ese pueblo.

-Esos manes son la autoridad, y no dejan ni siquiera quemar bareta. Mariguanero mal parqueado, de una lo pegan.

Yo, la verdad, a pesar de que en el fondo lo que me llena es eso que llamaríamos profesión: sensibilidad social y política, me quedo pensando más que en los paras y su empresita de guerra, pienso en aquello de las caricias sin promesas de amor... El tío Raúl no llama a los pelados; pero espera que vengan a saludarlo... Creo que quiere tener razones para copiar algo bonito de sus hijos, como que aún lo recuerdan; pero hace mal el tío en no contribuir a un posible encuentro con sus pintas, sobre todo con el Santiago. Él es el mismo Raúl en pasta. Lo digo yo que siempre me parecí a él cuando era un niño, bueno eso es lo que dice mamita Gélica, y las tías... Pero es que Santiago se ríe como el tío, camina como el tío, corre como el tío... Es hasta barrigón como siempre lo ha sido su padre, salvo en aquella mala época en que se dejó con Patricia y se regresó a vivir con los abuelos. Es que los sentimientos y el amor, sobre todo el amor, también desgastan y acaban: desgastan los afectos y la disposición y acaban con uno... Por eso Raúl mejor se fue a ver otras tierras, a descansar de esta vereda que se lo quiere tragar a uno a las malas. Medellín es una vereda que quiere tragarnos con esas miradas escapadas que cabalgan en medio de amarguras, miradas de putas que te miran por pura necesidad... Y mi tío va de acera en acera esperando encontrar una dama que no le cobre más que la tarifa.

¡Quiere caricias que no aspiren a un futuro!

Raúl me cuenta estos deseos mientras nos tomamos unas cervezas, y después de contarme sus cosas, empieza a preguntarme...

— ¿Camellando o estudiando? ¿Qué va a hacer después? ¿Que vas a escribir un libro? Eso, siga haciendo cosas sanas. Y déjese de mariguanadas... Vea que por acá, ya están llegando también los Paras.

$\infty \infty \infty$

Para cuestionar la presencia o ausencia de los padres, se requiere avanzar más sobre tres hipótesis que se han venido planteando estudiosos de la familia en Colombia y que el profesor Hernán Henao resumía así:

La cultura antioqueña, que dejó al varón sin instrumentos para enfrentar la pérdida de su prestigio en la función del proveedor económico, que ya no está en 
capacidad de soportar sobre sus hombros. Hablamos del pasivo psicológico, social y cultural del padre.

La revolución de género, agenciada por la mujer en la lucha por su identidad como la otra, que trasciende el sexo pero lo reivindica para sí a plenitud, que le disminuye intensidad a la maternidad y en línea directa desborda el ámbito doméstico en su accionar cotidiano.

La culpabilidad de doble naturaleza, que en la crisis social se les imputa a los padres. Al varón, por su débil figura para asumir el sexo y la intensidad que requiere una cultura que se construye. Y a la mujer, por su reiteración del discurso apologético o mítico, en lo relacionado con la presencia del nombre del padre de la familia y la cultura.

A partir de estas tres formas de análisis me propuse dar paso a las voces de los protagonistas de esas crisis; por eso este experimento etnográfico se constituye en una plataforma polifónica, una heterogloxia que evitará que el dialogismo de Bajtin degenere en una visión trivial de múltiples voces. Por ejemplo, podemos ver la función del parcero, quien asume la tarea socializadora que descuida el padre, los saberes, los afectos, las enseñanzas acumuladas, algo extraño que si no da paso a la reflexión, porque a veces creemos que de nada sirve, deja ver la dimensión social de la familia extensa que vincula otras circunstancias. 


\title{
28. De Jair y, de paso, de mi tío Ed
}

\author{
¡Que venga! ;Que venga! El tiempo que nos prenda. Tuve tanta \\ paciencia. Que olvido siempre. \\ Arthur Rimbaud, Una temporada en el infierno
}

Hace algún tiempo tuve la oportunidad de conocer a Jair, alguien a quien el cine - la imagen que cuenta historias - le proporcionó una idea distinta del mundo posible en esta selva de hienas que es nuestra sociedad, según dice él mismo. Una película que contaba la historia de Gandhi le enseñó a Jair alternativas distintas a la de matar al enemigo. Hasta entonces, jamás había visto posible algo distinto al uso de la violencia cuando se tratara de la defensa, de la sobrevivencia... (Y, así mismo, en algún momento pensábamos algunos). Hace un par de meses, Jair estuvo de gira por Miami, Boston, Road Island y Washington con la fundación para la No Violencia de Martin Luther King, y luego con otro expillo del Doce, se fue por Europa: Fráncfort, Estocolmo... en el marco del Festival de la Unión Internacional de Juventudes Socialistas, una asociación internacional de jóvenes socialistas defensores de la democracia y la solidaridad.

Estoy seguro de que pocos pueden hacerse una idea de Jair. Yo lo puse aquí, en medio de estas historias, porque él ha tenido que ver con nuestra historia: la del tío Ed, la de mis primos JF y Camilo, la de Osorio y, por supuesto, la mía.

Jair es un man grandísimo, de contextura gruesa y habladito especial. Un grandulón que no teme decir a qué le teme y que se escabulle entre palabras para decir, a su estilo, lo que siente... Desde hace mucho tiempo ha sido un líder natural de su barrio, uno de esos que creen en la paz entre combos de pillos, porque ha sido de esos combos y sabe de la necesidad de parar la guerra que desangra las laderas de la ciudad... Pero, a pesar de eso, no está de todo contento el hombre, pues no falta el que entorpece los procesos. Mostrándome las fotos de sus viajes por Europa y Estados 
Unidos, me muestra Jair el recordatorio de Alexander, el parcerito que andaba con él pa' todas partes... ¡lo mataron! Y se muestra muy humano el Jair al reconocer sus flaquezas, debilidades de hombre callejero:

-En estos días vi a un pelao que le dio bala a Ramón el hermano mío, yo no sabía qué hacer... Le quería hacer el mandado; pero me vi hablando de paz para afuera y por dentro confrontándome... Finalmente, no pasó nada porque me fui; pero seguro que él baja por aquí y me siento tentado... Y yo sé que a la final uno le ha hecho mal a mucha gente y que no falta el que conspire contra uno, como con ganas de cobrárselas... Probándome más de uno me torea a ver si de pronto me cojo otra vez con ellos... Así es esta sociedad.

Desde que conozco a Jair, siempre hemos querido hacer una película, una donde sin mucha moraleja mostremos que no es para nada chimba ser el duro del barrio. Él, desde siempre, supo de mi gustico por el video y, a la final, sabe que el tema me suena: la sangre siempre llama, dice un vallenato... Y sé que hay mucho por decir tras las historias de los pillos que triunfan.

Cuando nos disponíamos a hablar del Ed, el menor de los Tales, llegó Wbeimar, hermano menor de Jair, y compañero de mi tío cuando estudiaban bachillerato. Ya le había dicho al grandulón de mis pretensiones, pero hablar de amigos muertos es duro; él se lo pensó mucho, yo no insistí al notar su silencio, de pronto dijo:

— ¿El Tales? ¡El Tales! El gordito estudió fue con Wbeimar, pero a la final nos hicimos buenos amigos y nos íbamos a gaminiar juntos... Creció y resultó estudiando con el Tino, y se hizo amigo del Tino... Un día el Tino nos prestó una pistola, una $25 .$. como pa' salir a plaguiar por ahí. El Tales era bien... Lo recuerdo mucho, también al Osorio, ese que era su cuñado... Ed lo quería bastante. ¿Qué hubo de Ilsa y las niñas?... Y tus cuchos, ¿ todavía están ahí?

A Jair siempre le ha parecido que mi casa es la de mis abuelos y siempre ha creído que ellos son mis padres, es decir, siempre me asoció como hermano de Ed, pero sabe que soy su sobrino... Y, aun así, cree que los demás sobrinos de él también lo son míos...

-Y tus sobrinos los policías ¿qué? Había uno en Apartadó, ¿sí o qué...?

Wbeimar, el hermano de Jair, es mecánico industrial. Sabe de su hermano, lógicamente, de sus vueltas en el barrio, y supo también cómo eran las del tío Ed. Incluso hoy se pregunta por qué uno resulta amigado del malo, del vicioso... del que da mal ejemplo:

—Ed venía en su cicla — cuenta Wbeimar- y nos íbamos a andar por todo El Pedregal y Castilla. Nuestras ciclas no tenían frenos, entonces manteníamos 
gastados los pisos. Un día no podía ir con él, porque ya no tenía con qué frenar, y él me dijo que fuéramos a la casa, y me regaló unas garritas. Entonces ahí sí nos fuimos a andar... y andar. Pasó el tiempo y cuando se compró la moto, la AX 100, me la traía y yo se la revisaba y tal... Me acuerdo mucho de las hermanas de él, y de la cucha. Se les notaba que lo querían mucho, y él bien loco como era.

-Y el chino que lo mató también murió — dice Jair-. Siempre le dieron, pero se murió de una peritonitis el hijueputa ese... Era una gonorrea que mataba al que no le caía bien... Ese día el Tales vino y hablamos. Ya estaba muy periqueado, porque qué man pa' meter. Siempre me decía: "Metete, ome, mariquita”.

- Pero Ed camelló en fábricas Haceb — parece reivindicarlo Wbeimar-. Después se metió con las motos... y esos negocitos.

- Sí, yo lo conectaba con más de un man en el centro — se ufana Jair- - Y una vez vendió una con la que finalmente nos quedamos nosotros.

Y hubo también momentos de silencio en medio de los recuerdos. La evocación está cargada de silencios y suspiros. Por lo menos, yo me sollaba esos momentos viendo a Jair bien bacano, sentado, sin camisa, en pantaloneta, despreocupado de tombos y tanta vuelta viendo las mismas noticias de todos los días. Hablaban de un loco que en Cartagena se montó en pelota sobre el caballo de Bolívar, queriendo cabalgar... Hasta pensé que era el poeta Gómez Jattin. Wbeimar comiendo, y la cuchita de ellos renarrando el cuento ese: un loco en pelota montando en el caballo de Bolívar... Y Jair, como siempre, atacado de repente por las ideas, como de repente resultaba hablando... Y el silencio desplazado:

- Me mantengo en mi posición contra el sistema carcelario de este país... Es que este es el único país donde a unos nos dan la cárcel por casa y a otros la casa por cárcel.

Y me reinstalo unos segundos antes, trasladándome, en una foto donde Jair luce los moretones de una fuga... En los tiempos de policías y de ladrones, correteando calle abajo...

- Te acordás, Tales, cuando me cayeron los tombos. Yo me les tiré de un cuarto piso. Ve lo que me hice (señala Jair la foto) un morado en la pierna y no más...

El cuento de la no violencia sí que es interesante en un tipo así. Muchas veces, le manifesté a Jair mi alegría por lo que hacía y le pedí que no desistiera. Qué bacana la confrontación con uno mismo, y bacano cuando es uno el que gana...

—Yo me quiero ir pa' Bogotá, ome, Tales —insiste él_- Camellar en alguna cosa. Lo social ya no me gusta, ver morir a los amigos es muy duro; pero también he querido estudiar. El derecho me gusta mucho. La vuelta es que no he pasado a la de Antioquia, y pa' las otras no hay plata. Por lo de los viajes esos, conocí a una dura 
de la Bolivariana; pero que ellos dizque están muy mal de plata. Estoy esperando de pronto algo con monseñor como para entrar a la San Buenaventura... ¿Y vos sí te acordás de todo lo que hemos hablado, ome, Tales?

-Claro, parce... Así como me acuerdo de aquella vez que vimos juntos a Gandhi, la enésima vez que vos la veías.

Yo solo le dije eso, pero en el pensamiento tenía más para demostrarle el poder de mi memoria: recuerdo la cinta que vamos a hacer algún día: cómo vos recordás mi nombre y a mi abuela, a Ilsa y a las niñas...

Por la sala de la casa de Jair, salvando los obstáculos en que se vuelven los muebles, su pinta de unos seis o siete años corretea vendiendo corozos: "corozos a 50, corozos a 50...”.

Y yo me río y Jair apenas le dice:

-Hey, loquito ¿qué es lo que vendes?

$\cdots$

—Tales, tráenos la historia que escribas... — puntualizó Wbeimar mientras me acompañaba a la puerta.

— ¡Claro, parcero! - le contesté-. Mañana mismo la traigo...

Y me fui a casa exorcizado...

Mi tío Ed murió disgustado conmigo. Me puse un día a decirle cosas que no eran mentiras; pero que el gordo no quería saber más... Así soy yo, hablando siempre demasiado. Recuerdo que solo él me preguntaba por mis películas. No sé cómo sabía de las convocatorias del Ministerio de la Cultura y me decía:

—Quiubo, ¿qué ha mandado?

-Y quería el Ed que me regresara a Cuba.

-Aquí todo es una mierda, y no falta el que se lo quiera lamber a uno y uno que no se deja, entonces es cuando hay tropel...

Sí, señor. Aparece la pelea y el bochinche... Como dicen en su salsa los de la orquesta Lebrón. De eso es de lo que Jair se aburre. La pelea y el bochinche... Eso nos dejó sin mi tío Ed.

A propósito de salsa, en la última farra que vivimos juntos, me reclamó por un disco que le dediqué borracho. Ya no encuentro una justificación válida, y creo que nunca se la di; pero a él también le gustaba el disco ese... en la voz de Ángel Canales:

—Que yo conozco a Perico Macoña / un mulato sin igual... Se mete un cigarro 'e los finos y enseguida empieza a desvariar... Ese mulato es un puente roto, nadie lo puede pasar, se para en las esquinas / y a todo el mundo empieza a insultar... tiene problemas... Ayyyy, con toditas sus amistades... tra la la la la la... 


\title{
29. De un primo llamado Óscar
}

\author{
Eso sí, el día que nos llegue a faltoniar, que sea lengüilargo, que \\ se alce con una cosa, ese día se muere. \\ Alonso Salazar, No nacimospa'semilla
}

Cuentan donde Los Monos, unos vecinos de los Tales, que el tío H era una madre al lado de Óscar, "El Caleño". Que dizque tenía celda propia en la cárcel de tanto entrar y que por aquella época en que estaba de moda aquello de los reboliones, el Óscar decía haber estado en más de uno.

- Por esas mangas donde hoy es el barrio del Doce, como muchas parejas se metían por ahí, dado que eso era tan solo, los pillos los cogían de quieto y lleve... Violaban a las mujeres entre varios - cuenta uno de Los Monos-.

- ¡Severa moda! - pensaba yo.

¿Sobrino de Gélica o Fonso?... Nadie lo recordaba. Tuve que preguntárselo a mamita. Un día, mientras esperábamos turno para el médico en el Seguro Social de Bello, se lo mencioné y ella dijo que ni de riesgos era familia suya: que ÓsCAR, esa belleza, era familiar de Fonso y que prácticamente era el diablo:

- Con ese sí que había que estar pilas cuando estaba en la casa. Un día nadie supo cómo se le robó un radio a Alberto...

Que le ponían cuidado desde cuando llegaba... pa’ dónde se moviera tenía a uno encima, pendiente porque..., ave María, si era ratero. Qué hijuemadre.

-Un día se fue y no se le vio nada, pero cuando nos dimos cuenta fue que se había llevado el radio ese...

Y como que desde esa época donde Los Monos eran hasta de lo más queridos con los extraños...

—Comida no se le niega a nadie, ¡mucho menos un trago! 
En esa casa, dos más arriba de la de mis abuelos, muchos son como Pedro por su casa, y doña Ofelia, como que atendía muy bien al primo Óscar, así como a otros amigos de sus hijos mayores:

—Seguro por eso "El Caleño" nunca nos llegó a fallar — dice Darío, uno de Los Monos.

-Ese lo que era, era un ladrón el hijueputa. El único que lo quería por la casa era don Jorge —cuenta mi papá.

-Ese viejo era quien lo atendía, porque en la casa no lo dejamos volver a entrar - remata mi abuela.

—Él era hijo del hermano mayor de Fonso, y a lo último se fue pa’ Barranquilla y por allá lo mataron... - anota mi papá.

Pero Darío, sobria y hasta medio comprensivamente, comenta:

— "El Caleño" como que tuvo un problema grave en la casa. Mató a la mamá o la madrasta... Algo así.

Y la mamita Gélica me confirma el dato aquel día en el Seguro. En efecto, el hombre había matado a alguien:

-Cuando falleció la mamá, el papá ya tenía otra vieja por ahí lista pa’ casarse y el Óscar se la mató.

La verdad, yo no alcanzo a imaginarme al primo Óscar. A lo mejor tendría la pinta del primo Alberto, otro sobrino de Fonso; pero quizás más bien flaco y con una mirada mucho más asustadora. Aunque no descarto que fuera un pelao hasta pintoso, pues la Miriam, la única mujer en la casa de Los Monos, me confesó que fueron novios dizque por una noche, dice ella, y describió al Óscar como un tipo de unos ojos hermosos, buen cuerpo y una dentadura espectacular:

- Para nada comparable con el primo Alberto.

¿Qué le turbará a uno la mirada? Me pregunto a mí mismo. Además de la bareta, las penas. Solo en el velorio de Ed pude conocer a otros hermanos del papito, pues solo conocía a Virgelina, la mamá del “Gordo” Alberto, y a Francisco, y eso porque cuando él trabajaba en las Empresas Públicas un par de veces pasó por la casa leyendo el contador y mi mamá le sacaba juguito. Así que primos del cucho o tíos como para hacerme a una idea mucho más fiel del Óscar... Nada. Me da la impresión de que todos son medio parecidos de no ser por Francisco, que es moreno...

"El Caleño", un apodo hasta interesante para alguien que de seguro pocos recuerdan, y creo si este álbum llega a servir de algo, será para rememorar personajes, historias y anécdotas quizás ya difuminados en nuestros recuerdos... 
Esta etnografía es una experiencia testimonial que destaca una cultura particular. Se puede notar por las tradiciones y costumbres expresadas cada vez más con el parlache: un uso lingüístico que nos muestra una realidad a través de una simbología manifiesta en la oralidad de las personas entrevistadas... Narradas. Esta es la parte fuerte de lo que usted está terminando de leer: el ejercicio oral como trasfondo de este trabajo que marca el paso a lo largo de la obra, de las reflexiones que no construye del todo el etnógrafo, sino que las compone con lo que dicen los propios etnografiados... Como narrador, he venido proponiendo un juego dialógico que muchas veces resbala en un rasgo repetitivo, un lugar común, cierto anquilosamiento en lo anecdótico que considero, para bien, un nicho etnográfico del que intentan salir a flote rasgos teóricos que se disputan la vocería del autor, que no pretendo ser. Así parece que me pierdo en la repetidera de algunos asuntos, como la cita constante al uso drogas.

No pretendo explicar a fondo lo que propone este significante en el entretejido que es mi familia como práctica, como forma de ser y su conexión con la violencia, de eso hay mucho en Fumando mañas (Tapias, 2010). Aquí solo quiero ver que funciona como una verdad común, como una base de nuestra estructura simbólica, inconsciente forma de vida, material de escritura, ingrediente para una etnografía delirante sobre una familia disfuncional, como casi todas en nuestra sociedad... Y aunque parezca necesario revisar con cuidado este problema para dotar de sentido los diálogos y las situaciones que se presentan al lector, me pregunto hasta dónde importa el sentido. ¿Cómo tienen que ser los estudios de los fenómenos humanos y sociales para que resulten valiosos en sí mismos y sirvan, además, de orientación a los reformadores sociales? Responderá la crítica que esos estudios deben ser objetivos. Y ¿cómo lograr esa objetividad?

Las condiciones básicas para la conquista de la objetividad, según Linton (1965), son un punto de vista impersonal y un espíritu amplio. Soy amplio de mente y de espíritu, pero esto que trascribo no puede dejar de ser personal, autobiográfico, autoetnográfico... No soy objetivo, pero voy libre entre palabras que no pronuncio yo... Solo las recolecto. Y en el cómo las recolectó, en el método que empleo... Ahí está lo social científico:

Lamentablemente, existen prácticas muy extendidas entre los pretendidos científicos que, so copa de noble amor a la verdad, cubren deficiencias intelectuales y-ipor qué no decirlo? — prescripciones éticas, como la búsqueda de pruebas 
con el mero objeto de echar por tierra una teoría en boga, la racionalización para justificar un determinado plan, o restar importancia a hechos que no se ajustan a las propias ideas preconcebidas. (Martín López, 1993, p. 65)

"Ninguna ciencia que se ocupa de los seres humanos podrá alcanzar nunca el grado de objetividad de que son susceptibles las ciencias físicas y las biológicas. Nadie podrá estudiar a una persona con la misma impasibilidad con que estudiaría a una rata blanca o un fósil, pues se encontrará demasiado ligado al objeto de su estudio" (Linton, 1965, p. 12). El delirio de las drogas, en cuanto objeto que me sujeta a los demás, es un factor emotivo cuya influencia es cada vez más directa, pues el objeto es un fenómeno de la cultura.

Por eso esta etnografía escamotea varios problemas sin solucionarlos. Bosqueja una serie de factores emotivos que discurren... siendo historias... y ¿qué más puedo decir sobre esos factores, sobre esas historias?, por ejemplo, sobre mi padre que no deja de beber... Sobre mí que no dejo de drogarme... El problema, dice Reynoso, no es tanto ser o no objetivo, sino cómo lograr la objetividad. En un estudio como este ¿cómo podría ser objetivo si miro a mi propia gente? Además, lo hago tan embriagado como ellos... El camino no es propiamente la embriaguez, sino la escritura... ¿Escribir como borracho? ¿Estar tan borracho como el borracho? ¿Ser otro borracho?

Para salir de este embrollo, podemos ver a Piaget (1964), quien apoyado en los planteamientos marxistas propone que se reoriente la relación entre el sujeto cognoscente $(\mathrm{S})$ y el objeto de conocimiento $(\mathrm{O})$ para concebirla de forma dialéctica. Ello implica la existencia de una interacción mutua y en movimiento entre los dos elementos de la relación, como lo diría el filósofo chino Zhuang Zi, también llamado Chuang Tzu: de modo que mutuamente, opuestos, este y oeste (yo y el otro), somos incapaces de negarnos mutuamente... La dialéctica, como un interesante esfuerzo de síntesis... una salida que Ricoeur (1990) termina por aclarar cuando plantea entender que la objetividad no solo está ligada a la subjetividad que posee el científico social que reconstruye la historia o la cultura, sino, además, a la subjetividad del otro, entendiendo al “otro" en el sentido más amplio de la palabra. 


\section{Sniffffffff}

Las drogas dan respuesta parcial a los anhelos fundamentales del hombre; son un artificio para ponerse a salvo del dolor. Juan Cajas, El truquito y la maroma

Acabo de llegar de la calle

Con flores en mi cerebro

Y sonrisitas para todo el mundo...

Todos (en realidad, algunos), en el balcón bebiendo y bailando, ¡... Aaahh! Si el balcón de la casa de los abuelos hablara...

- Qué hubo, pues, fulano de tal, ¿muy loco o qué? —abordo a uno de mis primos.

- He, vení, metete un pase conmigo, mariquita.

No digo que sí, no digo que no

No digo que sí, no digo que no

No digo que sí, TAmpoco que no

Y ya estamos los dos metidos en el baño:

cosas como estas no debe haber

Visto mi abuela... aún

(Ella que incluso ha cogido in fraganti a más de uno con sus novias...)

—Tenés que ser el personaje de una de mis películas. Ome, perano — pienso yo mirándolo apenas sacar su perico de la billetera-. ¿Habrás leído de casualidad mi guion?: Cuatro actos hábiles, la adaptación de un cuento donde un mansito que se la pasa mete que mete cocaína en el baño de una discoteca y encuentra la mujer de sus sueños... ¡Es que hasta te sentás igualito, güevón!

Interior. Baño de discoteca. Noche. 
Escena 5. Un sanitario. Nuestro hombre (de nombre R) entra al baño y de espaldas, sentado a lo vaquero sobre el inodoro, saca su billetera para ponerla sobre el tanque.

La música se sostiene. Corte a:

Escena 6. Desplegada la billetera sobre el tanque, R saca un envuelto (rectángulo de papel celofán), una tarjeta telefónica de Orbitel y un billete de cinco mil pesos. El envuelto es abierto y sobre él, la tarjeta hace lo suyo: rápida y hábilmente pica un polvito blanco. Con el billete, R arma el "tubo de acceso" y su cabeza entra a cuadro. Aspira:

\section{R:Sniiifffffff}

Sonido en montaje alterno con siguiente plano sobre la música.

Escena 7. La mano izquierda de $\mathrm{R}$ suelta el sanitario para despejar las dudas de lo que hacía adentro.

La música se sostiene. Corte:

Vos, en cambio, tenés el guardado en un billete de dos mil, y una tarjeta plastificada de un alquiladero de películas...

- ¿De qué es esa tarjeta, ome, parce?

Y la tarjeta esa hace lo suyo: pica, montá, te lo arrimas a la nariz...

Sniiifffffff

—Te metiste tres, güevón —apelo yo sorprendido.

— Hoy estoy de cuenta de ellos, hijueputa — repunta él medio desvanecido ya.

- Mejor metete uno y no quemés tanta yerba, que te vas a volver loco.

-Loco, loco, ya estoy desde hace mucho tiempo, desde antes de conocerla... Entonces también le entro.

- Sniiifffffff, qué bravura, como que no lo sentí.

Luego, apenas me miro al espejo, estoy limpio; pero con la mirada itan perdida! Y el fulano de tal apenas guardándose lo suyo es pura pasividad... Deleite en su movimiento... Se goza entera la labor de guardar la billetera, y yo embelesado en mi misma mirada. Lo veo por el espejo... Como que amago abrir la puerta... Amago... Ambos supremamente arañados-trabados-embriagados... Amagados.

— ¡No, no. No, NO abras todavía! — azarado replica el fulano.

-Don't worry - contesto, queriendo brindarle un poco de seguridad.

—¿Quién sale primero? — pregunta el hombre, y yo... con mi tumbao lento... me imaginé pillado con los ojos rojos... mirada.

- Suyo es el honor caballero. Yo me refrescaré primero... A ver si limpio mi 
Y sale el fulano de tal con cierto caché... La fiesta lo está esperando y él cree que va como nuevo a pesar de su quijada inmóvil...

Yo me quedo echándome agua en la cara.

¡Está fría el agua!

Y si en el espejo, de pronto me miro, fijo

Resulta que no soy yo... 



\title{
31. "Caregato, vaya y tráigame un armao"
}

\author{
El machismo tumbero, la prosapia delincuencial, el archivo \\ policial, los peritos en el tema, y hasta los periodistas de \\ policiales, creen que la traición que sufre el ladrón casi siempre \\ está relacionada con una mujer. \\ Cristian Alarcón, Cuando me muera quiero que me toquen \\ cumbia
}

Madrugada del 25 de diciembre. He salido en moto con Mónica, la hija de la tía Hael, en busca de algo para su cabeza (y la mía), y terminamos donde Luz, la ex de mi tío H, "La Cucha”, como cariñosamente le dicen los del barrio. Ella no recuerda cómo me llamo yo y entonces pregunta. "César", dice Mónica. César... Y al comparar los ánimos con los que hemos llegado y las caras que vemos a nuestro alrededor, pienso, “iaquí es!". Música, ebrios y marihuana. La cosa se ve que pinta bien a pesar de tanta angustia. ¡Donde Luz se vende remedio para la angustia!

- Hey, pelada... ¿ ponemos para un cabezazo o qué?

-Pero aquí vende es el moño, primo...

Pero sin problema alguno, Mónica lo resuelve ahí mismo diciendo: "Luz, tráenos un porro, pues...”.

Y Luz llama al "Caregato", el patinador-mensajero de la plaza.

- Caregato, vaya y tráigame un armao... Acá no hay sino moño.

Luz le enseña a Mónica los traídos del niño Jesús para sus pelaos (Daniel, Tita, Mónica y Baba... y los sobrinos). Y está realmente orgullosa de haberlos conseguido ella misma, sola. El tío $\mathrm{H}$ los dejó hace ya algún tiempo, y entonces su frase de la noche es:

${ }_{i}$ H creyó que yo no podía sola!

Llega el bareto y, sin embargo, yo pienso en fumármelo de regreso adonde mi abuela... Un man, que está muy cerca de Luz, me mira y me ofrece un cigarrillo, 
que yo no rechazo. A Mónica también le da uno. No hay cenicero y, sin embargo, Luz dice que frescos:

-Tiren la ceniza ahí, que yo barro ahora.

Luego nos presenta...

— Gafíao, él es sobrino de Tales. César, él es un amigo mío...

Y el tal "Gafíao" me saluda y me ofrece gaseosa. Acepto. Mónica dice que también quiere una. Al final, yo soy el desconocido aquí. Pienso... La prima Mónica siempre se la ha llevado bien con las primas Asiley y Mónica, las dos mayores de $\mathrm{H}$. Por algún tiempo, quizás corto, incluso Asiley vivió donde Hael. Se dio entre ellas cierta confianza... Pienso que tal vez Mónica quiera hablar con ellas... A solas...

Una mujer delgada y de cabellos rizados, ya en la cumbre de su loquera, de ojos perdidos, me mira con la mirada que le queda y no cree que yo sea un Tales.

— iUsted no tiene cara de Tales!

Cuando "Gafíao" sale por las gaseosas, Mónica aprovecha para preguntarle a Luz qué le dio ese man.

- ¿Gafíao? - pregunta Luz.

-Sí, él mismo. ¿Qué te dio? — replica Mónica.

-Estos pisos, el jean y un dije de oro...

Se trataba de un dato ya conocido. El man nos lo había contado previamente, solo que Mónica lo preguntaba de nuevo como pa' seguir hablando, y distraer los malos sabores que a veces degusta el alma. Pienso que a lo mejor ella no quiere que le pregunte: “qqué pasa, Mónica?”. Se pondría a llorar de inmediato; pero se le nota que necesita hablar, y por eso fue que vinimos aquí... El viaje a punto de iniciar. Y en todo esto lo único que yo puedo hacer por ella es traerla a este otro lado... Pero, bueno, viendo al "Gafíao” pienso en el pobre de Tales, mi tío: pobre Tales si regresa. Lata o balín seguro que le sobra, ¡con todos estos manes como quieren a "La Cucha"! Es que a ella solo le falta bendecir a sus clientes y darles besos, para enfatizar más el amor que se reparte repartiendo vareta.

- Mi Dios le pague, cucha...

-La Virgen lo acompañe, mijo...

Hasta hace algún tiempo, el rumor era que $H$ estaba en la ciudad de Bogotá, en la Calle del Cartucho, pero hace un par de días le dijeron a Luz que sí, que H está por allá en Bogotá, pero gordo y lleno de bambas. Que dizque va a venir a matar a Luz, es el comentario... Y a ella eso no le preocupa tanto... si mi tío H supiera lo que piensa Luz de él...

—Yo no le deseo mal a H... ¡Es el papá de mis hijos! 
Y eso es seguro, incluso, de Luz siguen siendo culebra de las culebras de H...

-En estos días vi una gonorrea de flaco por allí. Me reconoció y yo le hablé: “vos fuiste el que le tiro a mi marido, gonorrea, todo bien”. Me monté un fierro y cuando volví por él... ¡nada! Se había esfumado como el humo... Por ahí me dijeron que le diera, que todo bien... Yo a esa gonorrea lo veo por ahí... Espere y verá...

Yo sigo fumando el Belmont que me ofrecieron. Llega la Coca-Cola y Luz me sorprende del todo:

-Préndase ese bareto ahí, todo bien.

- ¿Aquí?

- Hágale, que todo bien, y por la ceniza fresco, brilla los pisos.

Así, pues, don César, ¡candela, muchacho!

Estamos en la habitación de Luz. Mónica y yo sentados en su cama junto al "Gafíao". A un lado, una de la cicla "de traído de niño Dios” para uno de los muchachos y Luz mostrándonos la mercancía que le ayuda a sostenerse. Dos mancitos llegan a pedir "perico" y se van entrando a la casa como Pedro por su casa, y "Gafíao" se para de la cama y los aborda disimuladamente... como queriéndolos sacar. De buena manera, ellos copian y cogen pa' fuera. Luz, de todas formas, interviene:

-Fresco, "Gafíao", fresco, que ellos saben que yo estoy vendiendo...

Del palo donde pende la cortina de la ventana que da al pasillo central de la casa hay un angelito o un Niño Dios, qué sé yo. La figurita esa parece como de porcelana y tiene un hueco detrás: ahí está el polvo blanco que se vende como arroz.

- Mi Dios le pague, cucha...

—La Virgen los acompañe, hijos...

Y salen los manes esos mercados ya... ¡Mera noche buena la que tendrán! Sintiéndome medio extraño en esta casa adonde entra tanta gente, resulto ofreciendo fumadas de Cannabis como quien ofrece un pedazo de pan, y Luz dice "gracias, que todo bien", y me confiesa que con H se trababa en forma, pero que al "Gafíao" no le trama eso...

Y yo me quedo mirando al "Gafíao", pensando, mirándolo, asociando su rostro con el de un cómic, la nana de El conde Pátula, quizás... y me da la impresión de que lo que al "Gafíao" le trama es el perico. Solo es cuestión de ver su azare, cómo mueve la quijada. Incontrolable; pero es solo una impresión. Lo veo muy "gato". Me da la impresión, no más la impresión, de que está "gato" de tanto esnifffffarrr o güeler (¿cómo me veré yo?).

— ¿Que en estos días encanaron a Mónica? — pregunta Mónica la de Hael y Luz lo confirma... 
—Que dizque una vecina le delató la plaza. Y llegaron los tombos — que hasta se manejaron bien - y raqueta pa' todos...

Luz tenía una libra de marihuana que había querido guardar enseguida de su casa, pero el "Gafíao" insistió en que no: "todo bien, Luz". ¿Todo bien? Raqueta incluso para Luz y Mónica... Cuando menos pensó Luz, su Mónica, sin dejarse tocar, sacó el perico que tenía en los pantis. Luz la mira y ya qué se podía hacer... No la encanaron por ser menor de edad; pero que era muy grosera le dijo a Luz la juez de menores que atendió el caso.

La habitación de Luz, perfumada con hierba que se quema y Mónica (la de Hael) preocupada por sus ojos rojos-rojos, y yo le contesto, mientras que le doy una palmadita: "fresca, todos saben que estabas llorando".

Salimos de la casa de Luz. Una casa que tiene pinta de ser bien grande por dentro... Y llena de gente, que sale, que entra... Afuera los muchachos de la cuadra están armando un fogón para freír el chicharrón. Sigue siendo madrugada, y Luz, aparte, me invita a regresar a su casa. Y no espera respuesta mía, de una le dice a Mónica: "Gélica, vuelva y baje con él en estos días".

— ¿Gélica? - pregunto - ¿Por qué te dicen Gélica?

- Aquí toda la vida me han dicho así...

-Debe de ser por esos ojos tuyos que se parecen a los de mamita... ¿ ¿no? replico.

La Mónica, que traje en moto en busca de relax, de niña era una rechoncha lo más de linda, y aún sigue siendo hermosa, a pesar de las lágrimas y de algunas palabras fuertes alojadas en sus labios. Es ella quien dijo que nos fuéramos, preocupada obviamente por la "colinera" que yo tenía. El bareto quedó hecho cenizas y el espíritu levitando con cierta sensación... La tranquilizo: "fresca, prima, que vamos despacio".

Y aunque ella va tranquila, dignos efectos de la marihuana: el relax. No sé en realidad cómo fuimos de nuevo adonde la abuela... Despacio, a buen paso, velociferinamente... Mónica — creo- creyó en mí. Y nos fuimos juntos de regreso adonde estaban los borrachos que nos deja el Niño Dios cada diciembre en el balcón de la casa de los abuelos. Ya le había entregado su regalo de cumpleaños a la prima: una chocolatina. Solo faltaba esta historia. La maquiné en casa al despertar del viaje la mañana siguiente, bueno, en realidad la recordé para ella. 


\section{Tita, la del cabello dorado-derramado}

Everybody can't go to school a lot. Some people have to live,

man. ${ }^{*}$

Philippe Bourgois, In search of respect. Selling crack in El

Barrio

- Me gustaría estudiar; pero me da pereza, como me mantengo mucho con mis amiguitas. Además, entiendo poco, porque... como no presto atención y, además, el iprofe me tiene bronca!

- ¿Cómo es eso?

- Si él pregunta algo, yo contesto primero que todos; pero él no me pone atención... Y si mis amiguitas me hablan en clase y yo les converso... Ahí sí me ve... A veces me regaña delante de todos y entonces todos me gozan... Y empiezan hablar de mí, y a mí eso no me gusta... Me da rabia, sobre todo cuando me gozan y hablan a mis espaldas. Me siento mal... pero ¿yo por qué voy a quedarme callada cuando me gritan o me hacen algo?

- ¿Por ejemplo?

- Por ejemplo... En estos días una niña me quería pegar, y yo fui y le contesté que me diera, pues. Me empujó y yo ahí mismo la agarré del pelo... Al otro día ella y yo tuvimos que ir con la mamá ante el director...

A la niña de rizos de oro de cabello dorado-derramado sobre los hombros de mil quilates en pura sonrisa con ojos profundos y aventurados... Y de decisiones decididas al parecer (que a veces hasta parece contestoncita...). A ella dizque no le gustan los mariguaneros. Esa niña es Tita, la menor de las mujeres de "La Cucha" (y el tío $\mathrm{H}$ ).

* " No todo el mundo puede ir a la escuela. Algunas personas tienen que vivir, hombre". 
A Tita un computador le parece interesante. Le gustaría incluso estudiar eso... - Sí, es que de pronto no puedo estudiar medicina.

Solo a eso le gustaría ir a la universidad... A estudiar medicina. Por ahora va para sexto grado y le gustaría meterse a hacerlo en el Colegio El Rosal... La falla es que es un colegio de monjas y hay que pagar mensualidad; pero es que del Rosal mandan a los hospitales a las peladas de décimo grado cuando les toca eso del Vigía de la Salud... Solo por eso Tati iría al Rosal, por ir a los hospitales como le toca a Natalia, una amiguita suya. Un día Tita fue a Comfama, acompañando a Natalia a su clase de computadores y fue ahí cuando se dio cuenta de que le gustaría aprender eso también: computadores...

- Sí, es que de pronto no puedo estudiar medicina.

-Pelaíta, si le gusta eso y no tiene plata, dígale al profe de computadores que la deje entrar de vez en cuando. A lo mejor resulta usted más interesada que cualquiera de los que pagan... Piense qué quiere hacer... y averigüe... y cuente... y hable. Sea entrona como los de aquí - le dije yo.

Que ha pensado en el Colegio Alfredo Cook, me dijo también... que porque hay buenos profesores, según le dicen; pero el problema es que ahí entra mucho "mariguanero".

Ya he contado que en casa de Tita se vende yerba, y se fuma... y ella insiste en que a pesar de eso no le gustaría fumar nunca... Tita apenas tiene once años cuando escribo esta historia... Y ya está como decididita. Así por el estilo parece tener muchas más cosas claras... Por lo menos, las reflexiona.

Y en medio de esa claridad en la que al parecer se define, dice Tita que le gustaría ponerle atención a la clase, que quisiera ser más aplicada, pero es que las amigas le hablan y ella no se aguanta; sin embargo, me dice que va a intentar guardar silencio. Intentar guardar silencio. Intentar. Guardar. Silencio. Como si fuera un ángel. SilEnCiO.

El silencio es el hechizo del demonio, y cuanto más se calla, tanto más peligroso es el demonio; pero el silencio es también la conciencia del encuentro particular con la divinidad. Decía Kierkegaard, por allá en 1843. Y la Tita mirando un punto perdido, me va contando de sus ideas e intenciones, mientras de fondo la rutina de la casa:

-Una bolsita, mona.

Por la ventana, la bolsita de baretica, a seiscientos pesos cada bolsita...

El feo las arma y, de ñapa, regala un par de papeles smoking para enrollar... 
Viendo esa vuelta todos los días... Tita sabe que la gente gasta en eso DEMASIADO:

—Es una bobada fumar mariguana — dice-, quedan como bobos después de que fuman eso... ¡Y toda la plata que se gastan...!

Tita la del cabello derramado

Hoy de blusa azul

Y mejillas también azules

Tiene un par de mirellitas grandes en las mejillas... Piensa de pronto en volver a la clase, en acercársele el profe de la escuela y pedirle que la cambie de puesto.

- Que me ponga donde sea pero sola, adelante o en el medio... i pero sola! Y que ojalá el profe ya no la regañe más — dice-. ¡ Al menos no delante de todos!

- Haga las tareas — le digo a la Tita - Ponga atención, y si el profe es inteligente, lo notará.

-Y si no lo es, ¿qué?

—Ni se le ocurra decirle al profe que no es inteligente — le advierto—. Más bien, déjelo que muera engañado.

Y SE RíE TiTA. Mil quilates en pura sonrisa.

Los dientes de Tita son blancos-blancos.

Y me ponen a pensar en la bata blanca de los médicos.

Debe de verse linda esta niña como médica: vestida de bata blanca la doctora Tita Tales.

De cabello de oro y dientes blancos como la bata, como su esperanza. 



\section{La Coca-Cola mata el alcohol}

¡Sí! El tiempo reina, restaurando su brutal dictadura, y con su doble aguijón me empuja, como si yo fuese un buey: "camina, asno!, ;suda, esclavo! Vive pues, imaldito!" Charles Baudelaire, Spleen de Paris

El papito Fonso manda por un litro de "guaro". Yo me sorprendo: hace un buen tiempo que él no toma licor. En tanto llega el trago, lo pone en el mostrador de su tienda acompañándolo de Coca-Cola, según él, el mejor pasante. Y, así, sin más, arranca la historia tras mi pregunta:

-Fonso, ¿ cómo así que vos antes tuviste una salsamentaria?

— ¡No! Yo tenía era un granero ahí en el Pedrero, un toldo que llamábamos. Lo tenía con un amigo y vendíamos de todo.

—¿Cómo se llamaba el negocio, papito?

- ¿Con tanto granero que había por ahí! Noo, eso no tenía nombre. Era bobada ponerle nombre.

-Papito, cuénteme una historia suya de esos tiempos...

-Mmmm, a ver, hermano... Ah, sí, un día cualquiera el socio y yo entramos a un café y nos cogen los de ahí, hermano. A cascarnos, hermano, que no sé qué hijueputas y en fin... Era la época de la violencia política. Yo siempre he sido conservador. Toda la vida y nos rodearon todos los de ahí, hermano. Yo saqué la peinilla mía que era de 18 pulgadas y el amigo mío a volear taburetes, y como el cantinero era amigo de ellos, nos arrinconaron... Llegó la policía y yo tiré lo mío por allá detrás de unos bultos: ahí la perdí. Los policías eran dizque a ver que yo qué tenía. "Nada, señor agente", decía yo.

Me parecía estar viendo al tío Ed contándole a uno sus vueltas, así como hacía con el tío Hétor Mario un domingo después de sendas farras sabatinas; mientras, 
frente a la tele, iban desayunando. Y lo digo, sobre todo, por las posturas del papito cuando cuenta cómo se le arrimaron los tombos y la raqueta, y cómo pierde lo suyo, y tal y pascual...

-Yo expliqué que ellos nos habían buscado problema; pero, hablando, el amigo mío sí se rebotó, tanto así que... Fíjese el café ese donde estábamos: quedaba por allá llegando a San Juan. La estación de Policía quedaba sobre Cúcuta, como pa' los lados de las Empresa Públicas, y en ese trayecto lo iban a bajar por los lados del río (por donde hoy quedan los bomberos). Le iban era a dar la pela... A mí sí me devolvieron a la misma esquina. "Tranquilo, ombe, señor. Todo está bien”, dijeron.

Al otro día, el abuelo dizque fue a abrir el negocio y el socio no apareció. Muy al rato una llamada: que le mandara plata para poder salir. Había amanecido encanado.

- ¿Y usted entonces no volvió por allá, o qué?

—Eso se puso malo, hermano... Partimos, y a través de un paisano me coloqué en el Ferrocarril.

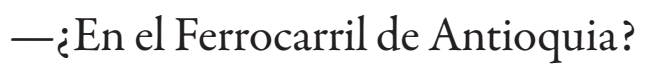

- Sí. Me mandaron a trabajar a la estación del Purgatorio, por los lados de Bolombolo, en medio de un cañón GRANDE; pero esa época fue demasiado dura. Se me murieron cuatro muchachos. Yo estaba muy mal... El paisano me llevó adonde el ingeniero de allá y adonde un doctor ahí medio marica él, y me colocaron en las Empresas. Eso fue un lunes, me acuerdo. Me avisaron al otro día que me presentara a las Empresas al miércoles. Entonces yo no fui a trabajar a la Estación, y el doctor me dijo que si podía empezar ahí mismo. Yo le dije que no, porque tenía que ir a devolver las herramientas. Entonces que me presentara el sábado, fue lo que me dijo. Fui a devolver las herramientas y esa gente ya pensaba que yo no iba a volver. Mi paisano y el ingeniero creyeron que ni a devolver las herramientas volvería, pero no, yo fui. Que no me fuera, que quédese, que le subimos el sueldo, que lo mandamos para donde quiera, me decían ellos. Y yo que no... Yo que no. Y eso que tenía de todo allá: prima, cesantías, vacaciones, todo; pero no, yo me fui pa' las Empresas.

- ¿Por qué te rogaron tanto? ¿Eras buen camellador?

— ¿Yo? Hooombe, yo siempre he sido un verraco pa' trabajar. Desde los once años. Pa' volear pico, pala, lo que fuera, hermano. Yo me subía unos bultos que, mejor dicho. Humm... quedaba mirando no más las piedras del camino y yo párriba... Imagínese que trabajando con el hermano mayor mío, yo me ganaba el jornal de hombre: unos treinta pesos y a él le daban el de menor de edad: doce o quince. Solo porque yo trabajaba duro...

— ¿Por qué tan camellador, pito? 
- Tuve un tío que me enseñó a trabajar: Benigno Valencia, se llamaba ese hijueputa, porque era un hijueputa, oís. No me podía ver para'o, hermano, ni dormido, porque me tiraba o me mandaba a tirar. ¡Ah! Pero al que más le aprendí fue al negro Palacio, un tipo GRANDE de Yolombó... GRANDE de unos brazos y unas muñecas gruesas. GRANDE el tipo, así como como el papá de este pelao Daniel, el que levantaron Hael y Fernando, de unos músculos también GRANDES, hermano. Estábamos por allá en El Retiro y un día llegaron unos estacones de 1,80 metros para alambrados, o sea, para separar los pastos del ganado en esas fincas inmensas. Le ofrecieron el trabajo a él y le dijeron que escogiera un ayudante, y Palacio me mira y dice: "Me llevo a Fonso". Él me explicaba mientras trabajaba y me ayudaba mucho a sopesar las cargas. PERO ÉL NO PONÍA LOS ESTACONES ESOS COMO TODos, nada. Y yo después de hacer los huecos dizque a sacar la tierra con las manos y él que no, pa’ eso está la barra y con la barra aprendí a sacar la tierra esa...

- ¿Cómo se ponían los estacones esos, pues?

-No... Era normal ponerlos con piamigos por un lado y por el otro; pero con Palacio nada eso, era sin nada: cuarenta centímetros del estacón metido en tierra y eso quedaba fino y derecho... Usted miraba así (y el papito coloca su mano al frente, como entre sus dos ojos y mira a lo lejos siguiendo el movimiento de la misma mano: al frente): y no era una fila de estacones por ahí puestos lo que usted veía... nada hermano, usted veía nada más que un estacón de lo derecho que quedaba eso, hermano... El primer estacón nada más.

— ¿Cómo fue la cosa en las Empresas?

- Bueno, el primer día en las Empresas me mandaron para acá, a los filtros de El Pedregal-Santander. Caminaba desde Bello para poder llegar, como vivíamos por allá. Después pagué alquiler en Santander hasta que conseguí este lote: $\$ 7200$ fue el préstamo para empezar a construir.

- ¿Y cómo era eso, el terreno y ya, ni una pieza?

- ¡Nada! Eso era una entrada a la cuadra y a los lados unos plancitos hechos por la misma máquina que hacía la entrada a la cuadra, de inmediato uno a abrir huecos pa' las cepas. La construcción era por cuenta de uno, con un préstamo del Instituto de Crédito Territorial. Todo eso se pagó en quince años, por cuotas...

La mamita Gélica se ha unido a la improvisada bebeta sobre el mostrador de la tienda.

—QQué 24 de diciembre más apagado! 
Y donde "Los Monos" extrañados que porque este año no había rumba donde los Tales... Ni donde los Tales, ni tampoco en más de una casa de por aquí, como donde los Madrid...

-Es que a doña Filomena apenas la operaron en estos días y le pusieron unas platinas... Y no ha estado como muy bien. Cuenta la abuela.

Un trago. Uno para cada uno.

A la mamita no le gusta pasar los guaros con nada, mucho menos con CocaCola, como lo hace el papito, dice que la Coca-Cola Mata el alcohol y entonces... ¿Qué gracia! 


\title{
34. A mi papá le tiemblan mucho las manos
}

\author{
Mi corazón se estremece oyendo de nuevo estos gemidos; un \\ oscuro temor me penetra hasta las entrañas cada vez que escucho \\ tu voz, y siento desvanecidas mis esperanzas. \\ Esquilo, Las coéforas
}

A mi papá le tiemblan mucho las manos. Difícilmente puede tomar su taza de chocolate sin derramar algo, y el temblor de su pulso lo hace incluso achantar... Yo no puedo mirarlo siquiera de frente. Aun sin proponérmelo, recuerdo sus regaños, cuando de niños, ni Carlos ni yo podíamos con nuestras tazas que entonces resbalaban de entre nuestras manos y el chocolate corría por la mesa, sobre el mantel, sobre nuestras piernas...

Y él, todo enojado...

A Luis Alberto Tales Cárdenas, el mayor de los hijos de Fonso y Gélica, le tocaba ir caminando hasta el colegio, de El Pedregal hasta el Estadio. Pero esas caminadas finalmente no fueron tanto tormento para él. Estudió en el Marco Fidel hasta tercero de bachillerato y no terminó siquiera ese año, porque si bien era bueno en las matemáticas, la dicha le duró hasta que conoció el álgebra; sin embargo, años más tarde, la geometría, la trigonometría, lo respaldarían en su carrera. Y dice Tales muy contento y orgulloso que al menos estudió...

-En esa época, la gente, a duras penas, terminaba la primaria, güevón, y eso que los que estudiaban eran personas ya adultas que se interesaban en salir adelante... Yo me pongo a ver lo que estudiábamos nosotros y lo que les enseñan a ustedes... Eh, ave María, llave...

Pero caminando no solo el cucho iba al colegio, hasta donde fuera iba caminando primero, después en bicicleta, a ver pasar la vuelta a Colombia, por ejemplo.

—Eran los tiempos de "Cochise” Rodríguez y "Pajarito” Suárez. 
Se trataba de una disputa entre titanes donde la radio y los periódicos eran cómplices-informadores y amplificadores de pequeñas grandes cosas con las que soñaba este país. Por esos días, casa donde hubiera radio, era casa de ricos, y el cucho pagaba diez centavos donde una vecina de la otra cuadra por oírse las carreras. Por entonces, Tales recogía tapas de los productos Pilsen y en el camión de la cerveza las cambiaba por una libreta con estadísticas y datos de las etapas, de los corredores y de la historia de la competencia. Tal vez desde ahí fue que conoció el alcohol... Y en esa libreta, del tamaño de la mano, anotaba los datos de cada etapa y de la clasificación general, seguro con más rigor que las fórmulas matemáticas, seguro con la misma dedicación con que años más tarde dibujara bobinas y toda clase de motores... Luego del colegio, asegura mi papá, que no capaba clases, era cuando iba al velódromo del estadio para ver entrar a "Cochise".

-Era tan bueno ese man, que competía él solo contra cinco más...

Y mi cucho no se aguanta las ganas y va a la biblioteca y saca de entre sus libros, su carpeta: las libretas esas con los datos de la Vuelta a Colombia en sus versiones XIV, XV, XVI, XVII, XVIII, XIX y XX y muy entusiasmado fue sacando luego las notas de sus años en el Sena.

En la biblioteca de la casa, desde el principio, el cucho se ha procurado un lugar para sus papeles-recuerdos de otros años... El cucho se fue al Sena a estudiar Electromecánica y Redes con el patrocinio de las Empresas Públicas de Medellín. Y siempre fue uno de los mejores. Sus estudios los hizo en el Sena de la ciudad de Cúcuta, entre 1968 y 1971. Sin terminar la secundaria, mi cucho se dio a hacer una tecnología mientras el mundo se organizaba en batallas de todo tipo y calibre, reclamando libertad —eran los tiempos de la Guerra Fría_, y cerca, muy cerca, estuvo el cucho de palpar esas protestas que al mundo le abrieron la mente: Tales era tan bueno en geometría y trigo, sus planos de circuitos eléctricos, transformadores y bobinas quedaban tan bien, que los franceses que asesoraban su carrera le ofrecieron irse a la Galia solo si renunciaba al patrocinio...

Pero al cucho siempre le han gustado las cosas serias y aseguradas. ¿Por qué desechar el futuro que le aseguraba la empresa gracias a la cual estudiaba? Mi papá entonces no se fue a Francia, y eso nunca le ha pesado. Fue mejor quedarse recibiéndoles clase a grandes maestros de la vida como el profe Arteaga.

-Arteaga era maestro de matemáticas, uno tan bueno que les daba clases a los demás profes... Enseñaba al escondido, porque todo el mundo lo buscaba. Era tan conocido que estaba garantizado que nunca nadie le daría trabajo... Arteaga disenó el Plan de Asalto al Cantón Norte. Allí el "eme” le robó al Ejército nacional un 
verdadero arsenal para la guerra... El Sena escondía a Arteaga con tal que enseñara, y yo fui su amigo...

El profe Arteaga hubiera podido falsear el diploma que nunca consiguió papá, me cuenta; pero ya era muy tarde cuando supo que el cucho no era bachiller... Si se lo hubiera conseguido, fijo el cucho hubiera podido ir más allá de Francia... pasar los Alpes, tal vez...

El gusto y el encanto del cucho por la vida, por mucho tiempo lo manifestó con el deporte. Nunca fue ciclista, pero corrió en más de una ocasión como atleta representando a las Empresas Públicas... Hasta se ganó un trofeo que con el tiempo terminó recibiendo del tiempo solo polvo... Las canchas de fútbol lo vieron corretear el balón con destreza cuando ya empezaba a crecerle la barriga y a notársele su nueva condición: empleado, casado, con hijos... Por la casa, montó con unos amigos un equipo superpoderoso que contaba con barra y con uniforme... el Jardín se llamaba: de camisa blanca y azul... como el Millos, aunque el cucho es hincha fiel del Medallo... Entonces era el futbolista que papito Fonso no le dejó ser, que era una pérdida de tiempo, le decía Fonso, correteándole el balón a mi papá... Le tacaba esconder los guayos y postergar la esperanza.

Un día, almorzando y oyendo radio, el cucho lanza su opinión frente el sistema social y político de nuestro país:

-A un Estado democrático no le interesa el deporte, ni la cultura, solo piensa en los puestos que ocuparán políticos baratos que no hacen más que robar... Ahí está la Vuelta a Colombia, que después de cincuenta años nunca ha sido un negocio rentable cuando en el mundo entero el ciclismo solo por decir el Tour de France es el segundo mejor negocio después del fútbol...

Esa es la opinión del cucho, que no deja de admirar países como Cuba, Rumania y la antigua Checoslovaquia, por su impulso al deporte y a la competencia. Aunque es seguro que la fijación del cucho va por encima de cualquier miramiento ideológico.

Pero un día, el cucho terminó embebido de alcohol. Y ese se volvió su nuevo culto... Y en pleno apogeo de la embriaguez no teme herirse o herirnos. Al preferir y desear morir borracho, bebiendo... ¿cómo se sentirían los familiares de Allan Poe, de Hemingway, de Bukowski... viéndolos morir?

No dejo de pensar en qué lugar habría escondido mi padre sus viejos guayos; supongo que algún vecino, o en un hueco junto a la Tinaja, la cancha de por su casa... al término de los años, tras elegir el alcohol, se le extravió la esperanza, el balón, el amor... 
Entonces, la radio de una vecina, su cicla pinchada por la Policía, la abuela, sus hermanas, el amor de mi mamá, el destino sobre la piel, se volvió alcohol y puños...

Extrañas formas de amor o de morir viviendo.

$\infty \infty \infty$

El tema más estratégico en todo el pensamiento de Linton es, sin dudas, las relaciones entre la cultura y la personalidad:

No puede dudarse que exista una estrecha relación entre esta configuración de la personalidad y la cultura de la sociedad a la que el individuo pertenece. La cultura, en todo lo que sea más que una abstracción creada por el investigador, existe solo en las mentes de los individuos que componen una sociedad. Derivan de ella, todas las cualidades de sus personalidades y de la interacción de estas personalidades. Y a la inversa, la personalidad de todo individuo perteneciente a la sociedad, se desarrolla y funciona en constante asociación con su cultura. Las personalidades afectan a la cultura y la cultura a cada personalidad. (1965, p. 447) 


\section{La mamita está borracha}

Para obviar estos peligros, lo mejor para mi es, creo, huir.

François Villon, Poesía

Fernando (el papá de Fred, JF y Mónica) y yo la subimos hacia su habitación.

Insistentemente, ella no deja de decir: "No me vayan a dejar caer. No me vayan a dejar caer... No me vayan a dejar caer. No me vayan a dejar caer. Ay, juemadre... No me vayan a dejar caer”.

$\infty \infty \infty$

Con este texto he querido compartir algunas de las historias que me constituyen como individuo y como miembro de un grupo. Quedan revelados aquí nuestros pensamientos y la forma de comunicación que empleamos. Son reflexiones en torno a la dialéctica individuo-sociedad, puestas en una plataforma global para considerar a la sociedad a través del microuniverso que es la familia, en cuanto conjunto de interacciones, de asociaciones entre sujetos, de relaciones sociales. Una serie de aspectos relacionados con términos como identidad social, grupos sociales, roles sociales, sistemas simbólicos y, por supuesto, construcción de sentido. Para cerrar, en palabras de Alfred Schütz, quiero reiterar que esta etnografía nos ha servido para reconocer que:

Alvivir en el mundo, vivimos con otros y para otros, y orientamos nuestras vidas hacia ellos. Al vivenciarlos como otros, como contemporáneos y congéneres, como predecesores y sucesores, al unirnos con ellos en la actividad y el trabajo común, influyendo sobre ellos y recibiendo a nuestra vez su influencia, al hacer 
Historias de familia

todas estas cosas, comprendemos la conducta de los otros y suponemos que ellos comprenden la nuestra (1979, p. 39). 


\section{Epílogo}

Mi oficio es ver $y$ anotar.

Gabriel García Márquez

En la noche luego del entierro del abuelo Fonso

La casa, como encantada, se sostuvo ante la pena

$\mathrm{H}$ sonreía en la cocina en medio de la conversación

Donde estaba alguno de cada generación, mi abuela, mi tía Rubiela, mi primo Andy...

Recuerdos, sonrisas y penas

Lágrimas y tranquilidad

Entre todos nadie era extraño

Solo estaba ausente mi papá que, deprimido, se embriagaba

Y como cualquier otra noche

La mamita se preocupaba era por la comidita para todos

Ilsa, Cristina, Paula, Santiago...

El tío Raúl no pudo llegar ni al cementerio

En el balcón, acompañado de tragos

Justificó su enfado con el amor

En la sala se respiraba esperanza

Katherine le leía a Santiago, el niño del tío Hétor, letra por letra...

La familia Tales Cárdenas invita a las exequias del Luis Fonso Tales Cárdenas

Yo deambulaba por la casa detrás de mi abuela

Inalcanzable mientras preguntaba: ¿quién falta por comer?

— ¡Falto yo, mamita, falto yo!

Pero mamita no me oía

No había mucho silencio en la casa 
La vida reflexionaba la muerte

Comíamos la cena entre pesares

Necesitábamos sal y grasa para soportar el trago de la noche que llegaba Suspiros

Mi abuela dice que quisiera salir corriendo...

Es demasiado

Recorrí la casa sintiéndome invisible

Imaginando el espíritu del abuelo viéndonos

Llovía

Fui a enjugarme las penas 


\section{Glosario}

Alpaca: $f$. Mamífero rumiante suramericano.

Aleteadas, aletiadas: adj. Dicho de una persona que se encuentra en estado de alerta. Arrocito en bajo: expresión coloquial para designar otras opciones, otro amor que espera...

AUC: iniciales del grupo armado ilegal Autodefensas Unidas de Colombia, también llamados Paras.

Azarado: adj. Asustado, alerta.

Bacano: adj. Para ilustrar que algo luce bien, o que gusta.

Balín: balas, balacera.

Bareta: s. Para designar la marihuana.

Bolis: $s$. Refresco de sabores que se vende congelado, como hielo.

Cachonear: $v$. Designa gastar, invertir en alguien con una segunda intención.

Caliente: adj. Que designa el grado de peligrosidad de un lugar o persona.

Camello:s. Trabajo, ocupación.

Colinera: $s$. Para designar el estado alterado de conciencia tras el uso de alucinógenos.

Copiar: de los verbos, obedecer, creer.

Culebra: adj. Deuda, deudor.

Empeliculao: adj. Que designa que alguien cree como real una fantasía, o mentira.

Enfierrao: adj. Armado, cargado de armas.

Escopolamina: $s$. Droga altamente tóxica también conocida como burundanga.

Faltoniar: $v$. Faltar a la moral, engañar, traicionar.

Fierro: $s$. arma, revolver o pistola.

Gatilleo: $s$. Usar armas, disparar.

Guaro: $s$. Nombre popular para el aguardiente.

Jevita: $s$. O evita, diminutivo de Eva, mujer.

Lata: $s$. Navaja o arma blanca.

Lucas: $s$. Que se refiere a dinero en abundancia. 
Merca: s. O mercancía, palabra para nombrar la cocaína que se exporta.

Reboliones: $s$. Violación sexual.

Niquía: s. barrio tradicional del municipio de Bello.

Orbitel: Antigua marca de la empresa de telefonía celular en Medellín.

Pegar: $v$. Matar, masacrar...

Peinilla: $s$. Herramienta de trabajo y arma blanca, también conocida como machete.

Pelaíto: $s$. Niño, joven.

Perico: s. Cocaína.

Periqueado: adj. Estado alterado de conciencia por uso de cocaína.

Pinta: s. Que designa hijo, descendiente.

Pintoso: $a d v$. Que luce atractivo.

Plaguiar: $v$. Hacer maldades, hacer daños.

Snif: $v$. Esnifar, aspirar.

Raqueta: $s$. Revisión violenta por parte de la Policía.

Tárogato: s. Campana.

Tombos: s. Policías.

Torreón: $m$. Torre grande para defensa de una plaza o castillo.

Visajosos: adj. Para calificar actitudes demasiado vistosas.

Vueltas: s. Historias, responsabilidades... 


\section{Bibliografía}

Alarcón, C. (2010). Cuando me muera quiero que me toquen cumbia. Bogotá: Norma. Agar, M. (2008). Hacia un lenguaje etnográfico. En El surgimiento de la antropología posmoderna. Barcelona: Gedisa.

Auster, P. (1990). The locked room. In The New York Trilogy. New York: Penguin Books.

Bajtin, M. (1953). Discourse in the novel. En Holquist, M. (comp.), The dialogic imagination. Austin: University of Texas Press.

Baudelaire, C. (1997). Spleen de París. Madrid: Visor.

Beauchamp, P. y otros (1977). La reconstitution automatique des familles: un fait acquis. Paris: Population.

Benjamin, W. (1982). Discursos interrumpidos I. Madrid: Taurus.

Berger, P. L. y Kellner, H. (1983). Marriage and the construction of reality. En M. Anderson, Sociology of the family. London: Penguin Books.

Bloom, H. (2000). Shakespeare: la invención de lo humano. Bogotá: Grupo Editorial Norma.

Bourdieu, P. (1989). La ilusión biográfica. Historia y Fuente Oral (2).

Bourdieu, P. (1993). La miseria del mundo. México: Fondo de Cultura Económica.

Bourdieu, P. (1997). Capital cultural, escuela y espacio social. México: Siglo XXI.

Bourdieu, P. (2000). Cuestiones de sociología. Madrid: Akal.

Bourdieu, P. y Wacquant, L. (2005). Una invitación a la sociología reflexiva. Buenos Aires: Siglo XXI.

Bourgois, P. (1995). In search of respect: Selling crack in El Barrio. Cambridge: Cambridge University Press.

Buitrago, A. (2012). El hombre que no quería ser padre. Bogotá: Planeta.

Bukowski, C. (2008). Púrpura como un Iris. En Escritos de un viejo indecente. Barcelona: Anagrama. 
Cajas, J. (2009). El truquito y la maroma: cocaina, traquetos y pistolocos en Nueva York. Popayán: Editorial Universidad del Cauca.

Cioran, E. M. (1973). La tentación de existir. Madrid: Taurus.

Coetzee, J. M. (2009). Diario de un mal año. Bogotá: Random House Mondadori.

Conrad, J. (1996). El corazón de las tinieblas. Veracruz: Universidad Veracruzana.

Corcuff, P. (2005). Las nuevas sociologias. Madrid: Alianza.

Crapanzano, V. (1980). Tubami: Portrait of a Moroccan. Chicago: University of Chicago Press.

Cusinato, M. (1992). Psicología de las relaciones familiares. Barcelona: Herder.

Delgado, M. (2003). Naturalismo y realismo en etnografía urbana: cuestiones metodológicas para una antropología de las calles. Revista Colombiana de Antropología, 39, 7-39.

Departamento Administrativo Nacional de Estadística (DANE), (1998). La familia colombiana en el fin de siglo. Bogotá: autor.

Devereux, G. (1977). De la ansiedad al método en las ciencias del comportamiento. México: Siglo XXI.

Donati, P. (2003). Manual de sociología de la familia. Pamplona: Eunsa.

Durkheim, E. (1975 [1895]). Fonctions sociales et institutions. Paris: Minuit.

Durkheim, E. (1976).Les regles de la methode sociologique. Paris: Presses Universitaires de France.

Elias, N. (1983). Compromiso y distanciamiento. Barcelona: Península.

Engels, F. (1884). El origen de la familia, la propiedad privada y el Estado. Moscú: Progreso.

Espinas, A. (1877). Des societes animales: étude de psychologie comparée. Paris: Baillière.

Espinosa, N. (2010). Politica de vida y muerte: etnografía de la violencia diaria en la sierra de La Macarena. Bogotá: Instituto Colombiano de Antropología e Historia.

Esquilo (2008). Las coéforas. En Fragmentos y testimonios. Madrid: Gredos.

Fante, J. (1989). Pregúntale al polvo. Barcelona: Paidós Ibérica.

Geertz, C. (1973). The interpretation of cultures. New York: Basic Books.

Gimeno, A. (1999). La familia: el desafio de la diversidad. Barcelona: Ariel.

Goethe, J. W. von (2009). Fausto. Madrid: Espasa-Calpe.

Goffman, E. (1974). Frame analysis. Boston: Northeastern University Press.

Gómez Jattin, R. (2004). Amanecer en el valle del Sinú: antología poética. Bogotá: Fondo de Cultura Económica. 
Gramsci, A. (1975). Quaderni del carcere. Torino: Einaudi.

Gutiérrez de Pineda, V. (1968). Familia y cultura en Colombia: topologías, funciones y dinámica familiar. Bogotá: Tercer Mundo-Universidad Nacional de Colombia.

Gutiérrez de Pineda, V. (1975). Familia y cultura en Colombia. Bogotá: Instituto Colombiano de Cultura.

Gutiérrez de Pineda, V. (1983). Avances y perspectivas en los estudios de familia. En Avances y perspectivas en los estudios sociales de la familia en Colombia. Medellín: Universidad de Antioquia, Facultad de Ciencias Sociales con la colaboración del Instituto Colombiano para el Fomento de la Educación Superior (Icfes).

Gutiérrez de Pineda, V. (1998). Cambio social, familia patriarcal y emancipación femenina en Colombia. Revista de Trabajo Social (1).

Gutiérrez de Pineda, V. (2003). Familia ayer y hoy. En Familia, género y antropologia: desafios y trasformaciones. Bogotá: Instituto Colombiano de Antropología e Historia.

Gutiérrez Sanín, F. (2013). Un elogio de la facilidad. El Malpensante (140), 27.

Guber, R. (2001). La etnografía, método, campo y reflexividad. Bogotá: Grupo Editorial Norma.

Guber, R. (2004). El salvaje metropolitano: reconstrucción del conocimiento social en el trabajo de campo. Buenos Aires: Paidós.

Habermas, J. (1981). Teoría de la acción comunicativa (2 vols.). Madrid: Taurus.

Hernández, A. (1991). Estrés en las familias colombianas, tensiones tipicas y estrategias de afrontamiento. Bogotá: Universidad Santo Tomás.

Hernández, A. (1998). Familia, ciclo vital y psicoterapia sistémica. Bogotá: El Búho.

Hinojosa, F. (2006). Ana, ¿verdad? México: Alfaguara Infantil.

Henao, H. (1989). Familia, cultura y juventud. Cuadernos de Familia (5).

Henao, H. (1995a). Aspectos de familia en Medellin: años 80 y 90. Medellín: Instituto de Estudios Regionales (INER)-Universidad de Antioquia.

Henao, H. (1995b). Medellin: ciudad depueblos y violencias. Reflexiones sobre la socialización en situaciones de conflicto. Medellín: Instituto de Estudios Regionales (INER)-Universidad de Antioquia.

Houellebecq, M. (2005). El mundo como supermercado. Barcelona: Anagrama. Kierkegaard, S. (2003 [1843]). Temor y temblor. Buenos Aires: Losada.

Krotz, E. (1991). Viaje, trabajo de campo y conocimiento antropológico. Alteridades. Revista de Ciencias Sociales de la UAM, 1 (1), 50-57. 
Jiménez Caballero, C. (2006). Desobedecer para convivir: construcción de ciudadanía y campo psicosocial. Bogotá: Corporación para el Desarrollo Picacho con Futuro.

Jimeno, M. y Roldán, I. (1996). Las sombras arbitrarias: violencia y autoridad en Colombia. Bogotá: Universidad Nacional de Colombia.

Kapuscinski, R. (2000). Ébano. Barcelona: Anagrama.

Leiris, M. (2007). El África fantasmal: de Dakar a Yibutu (1931-1933). Valencia: Pre-Textos.

Lessing, D. (2007). La grieta. Bogotá: Random House Mondadori.

Lévi-Strauss, C. (1997). Tristes trópicos. Barcelona: Paidós Ibérica.

Linton, R. (1965). El estudio del hombre. México: Fondo de Cultura Económica.

Macías, M., Paternina, A. y Vargas, K. (2004). Relaciones familiares en familias desplazadas por la violencia, ubicadas en La Cangrejera (corregimiento de Barranquilla, Colombia). Psicología desde el Caribe (14), 91-124.

Magalhães, T. (2010). Violencia e abuso. Coimbra: Coimbra University Press.

Martín López, E. (1993). Textos de sociología de la familia: una relectura de los clásicos (Linton, Tönnies, Webery Simmel). Pamplona: Rialp.

Marx, C. (1990 [1847]). Miseria de la filosofía. Medellín: Bedout.

Mishima, Y. (2003). El rumor del oleaje. Madrid: Alianza.

Molano, A. (1989). Siguiendo el corte: relatos de guerras y de tierras. Bogotá: El Áncora. Murakami, H. (1999). Sputnik, mi amor. Barcelona: Tusquest.

Oé, K. (1994). La presa. Barcelona: Anagrama.

Onfray, M. (2008). La fuerza de existir: manifiesto hedonista. Barcelona: Anagrama.

Pasolini, P. P. (1971). Discurso sobre el plano secuencia o el cine como semiología de la realidad. En AA. VV., Problemas del nuevo cine. Madrid: Alianza.

Piaget, J. (1964). Seis estudios de psicología. Barcelona: Seix Barral.

Rabinow. P. (1977). Reflexions on fieldwork in Morocco. Barkeley: University of California Press.

Ramírez, H. (1975). La ausencia del descanso. Medellín: Editorial Universidad de Antioquia.

Reynoso, C. (Comp.), (2008). El surgimiento de la antropología posmoderna. Barcelona: Gedisa.

Rico de Alonso, A. (1986). Madres solteras adolescentes. Bogotá: Plaza y Janés.

Rico de Alonso, A. (1999). Formas, cambios y tendencias en la organización familiar en Colombia. Nómadas (11), 110-117.

Ricoeur, P. (1990). Historia y verdad. Madrid: Encuentro. 
Rimbaud, A. (2005). Una temporada en el infierno. Buenos Aires: Longseller.

Rosero, E. J. (2000). Cuchilla. Bogotá: Norma.

Salazar, A. (1990). No nacimos pa'semilla: la cultura de las bandas juveniles en Medellin. Bogotá: Booket.

Satir, V. (1978). Las relaciones humanas en el núcleo familiar. México: Trillas.

Sarmiento, M. (1994). Psicoprofilaxis familiar. Bogotá: Editorial Universidad Santo Tomás.

Scheper-Hughes, N. y Bourgois, Ph. (2004). Violence in war and peace: An anthology. Oxford: Blackwell.

Schütz, A. (1974). El problema de la realidad social. Buenos Aires: Amorrortu.

Schütz, A. (1979). El problema de la realidad social. Buenos Aires: Amorrortu.

Schütze, F. (1983). Biographieforschung und narratives Interview. Berlín: Neue Praxis.

Spivak, G. (2003). ¿Puede hablar el subalterno? Revista Colombiana de Antropología, 39, 297-364.

Tapias, C. (2010). Fumando mañas: construcción del sentido de la realidad social en un contexto de ilegalidad. Bogotá: Universidad Colegio Mayor de Nuestra Señora del Rosario.

Tapias, C. (2012). La fotoprovocación como método: fragmentos de memorias a través de imágenes. En N. Espinoza, A. Góngora y C. Tapias (Comps.). Nuevas antropologias colombianas: experiencias metodológicas. Montería: Zenú.

Taussig, M. (2002). Chamanismo, colonialismo y el hombre salvaje: un estudio sobre el terror y la curación. Bogotá: Grupo Editorial Norma.

Thomas, W. I. y Znaniecki, F. (1996). The Polish peasant in Europe and America: A classic work in immigration history. Springfield: University of Illinois Press.

Tyler, S. (1986). Postmodern ethnography: From document of the occult to occult document. En J. Clifford y G. Marcus (Comps.), Writing cultures. Berkeley: University of California Press.

Tocqueville, A. de (1996). La democracia en América. México: Fondo de Cultura Económica.

Tovar, P. (2003). La familia en tiempos de guerra y la guerra dentro de la familia. En Familia, género y antropologia: desafíos y trasformaciones. Bogotá: Instituto Colombiano de Antropología e Historia.

Vargas Llosa, M. (2010). La guerra del fin del mundo. Bogotá: Santillana.

Wilson, B. (1969). La religión en la sociedad. Barcelona: Labor.

Zilahy, L. (1970). Las cárceles del alma. Barcelona: Círculo de Lectores. 
Este libro fue compuesto en caracteres Garamond Premier Pro 11,5 puntos, impreso sobre papel propal de 70 gramos y encuadernado con método Hot Melt, en el mes de noviembre de 2014, en Bogotá D. C., Colombia 